\title{
RECURRENCE AND EXTENT OF GREAT EARTHQUAKES IN SOUTHERN ALASKA DURING THE LATE HOLOCENE FROM AN ANALYSIS OF THE RADIOCARBON RECORD OF LAND-LEVEL CHANGE AND VILLAGE ABANDONMENT
}

\author{
Ian Hutchinson \\ Department of Geography, Simon Fraser University, Burnaby, British Columbia, Canada V5A 1S6. Corresponding author. \\ Email: ianh@sfu.ca. \\ Aron L Crowell \\ Arctic Studies Center, Smithsonian Institution, 121 West 7th Avenue, Anchorage, Alaska 99501, USA.
}

\begin{abstract}
The incidence of plate-boundary earthquakes across 3 prospective tectonic segments at the Alaska subduction zone (ASZ) in the late Holocene is reconstructed from geological evidence of abrupt land-level change and archaeological evidence of discontinuities in occupation of native villages. Bracketing radiocarbon ages on uplifted and down-dropped coastal deposits indicate that great earthquakes likely ruptured the plate interface in the eastern segment (Prince William Sound [PWS]) about 800, 1400, 2200-2300, 2600-2700, 3100-3200, and 3600-3700 cal BP. Evidence for an event about $1900 \mathrm{yr}$ ago, and the possibility that the 2600-2700 cal BP event was a closely spaced series of 3 earthquakes, is restricted to parts of Cook Inlet. Geological evidence from the central (Kenai [KEN]) segment is fragmentary, but indicates that this segment likely ruptured about $1400 \mathrm{yr}$ ago and in the triple event about 2600-2700 yr ago. The geological record from the Kodiak-Katmai (KOKA) segment at the western end of the ASZ has limited time-depth, with localized evidence for ruptures about 500, 1000, and $1300 \mathrm{yr}$ ago. ${ }^{14} \mathrm{C}$ ages and stratigraphic descriptions from 82 prehistoric villages and camps on the coast of the Gulf of Alaska reveal fluctuations in site activity that correlate with paleoseismic episodes. Hiatuses in site occupation occurred about 800, 1400, and $2200 \mathrm{yr}$ ago in the PWS and KEN segments. The fragmentary older record from the KEN segment also reveals a hiatus about 2700 yr ago. The 2200-2300 and 2600-2700 cal BP events are also recorded in the KOKA segment, and the great earthquake at about $3200 \mathrm{cal} \mathrm{BP}$ may also be recorded there. This suggests that, although the PWS and KEN segments behave as a coherent unit of the Alaska megathrust, the KOKA segment is characterized by semi-independent behavior. At least 2, and perhaps as many as 4 , of the last 7 prehistoric great earthquakes at this plate boundary did not propagate this far west.
\end{abstract}

\section{INTRODUCTION}

On 27 March 1964, abrupt release of strain at the interface of the Pacific and North American plates in southern Alaska produced the second largest earthquake of the 20th century $\left(\mathrm{M}_{\mathrm{w}}=9.2\right.$; Kanamori 1977). The main shock and attendant aftershocks ruptured an area extending from about $100 \mathrm{~km}$ east of the epicenter in Prince William Sound to just west of the Kodiak Archipelago, and inland from the Aleutian Trench to the northern shores of Cook Inlet and Shelikof Strait (Figure 1). Instantaneous coseismic deformation of the Alaska continental margin generated a Pacific-wide tsunami, which, in concert with local tsunamis produced by subaerial and submarine landslides, accounted for 106 of the 115 deaths attributed to this earthquake in Alaska (Lander 1996).

Geological evidence of similar episodes of abrupt crustal deformation during the late Holocene at the eastern end of the 1964 rupture zone suggests that the mean recurrence interval of great earthquakes is about 700-800 yr (Plafker et al. 1992; Combellick 1994; Plafker and Rubin 1994). The geologic record of paleoseismic activity at the western end of the Alaska subduction zone, however, is much more fragmentary (e.g. Davies et al. 1981). Consequently, important source parameters such as the rupture area and seismic moment of prehistoric plate-boundary earthquakes cannot yet be constrained.

The objective of this study is to attempt to reconstruct the chronology and rupture length of plateboundary earthquakes at this subduction zone, by integrating published geological information on abrupt land-level changes with archaeological evidence of episodes of native village abandonment. The archaeological record along the southern Alaska coast represents a potentially rich, but essen- 


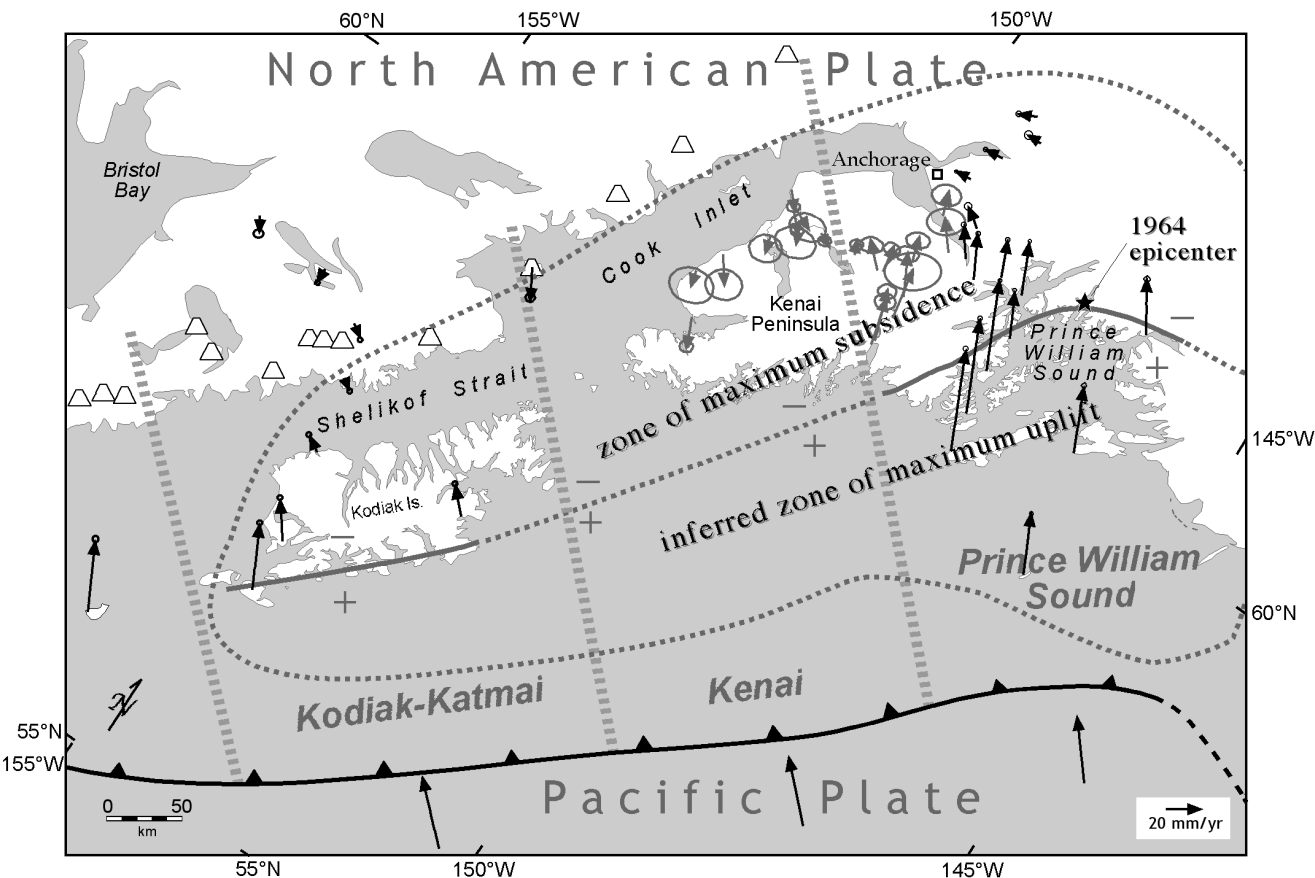

Figure 1 The Alaskan subduction zone showing the America-Pacific plate boundary (barbed black line) and areas of tectonic displacement in the 1964 earthquake. Light dashed lines mark the inferred boundaries of the tectonic segments proposed in this study. Arrows indicate current horizontal crustal velocities from GPS measurements (gray arrows show short-term campaign data). Cones mark arc volcanoes that have been active in Holocene time. (Sources of information: Plafker 1969; Plafker and Rubin 1992; Johnson et al. 1996; Freymueller et al. 2000; http://quake.wr.usgs.gov/ research/deformation/gps/auto/NA.html; http://www.avo.alaska.edu/volcanoes/region.php/atlas.htm).

tially untapped source of information on the frequency and extent of catastrophic events in the prehistoric period.

We use a simple segmentation model of the Alaska subduction zone to explore the spatial and temporal patterns of paleoseismic activity from geologic evidence of land-level changes, and compare these patterns with discontinuities in occupation of coastal native villages. We also attempt to discriminate between seismic and non-seismic causes of village desertion and population exodus, in an attempt to expand our understanding of the incidence and effects of great earthquakes in this area.

\section{TECTONIC SETTING AND SEGMENTATION OF THE ALASKA SUBDUCTION ZONE}

Wesson et al. (1999) treated the 1964 rupture area as a coherent segment of the America-Pacific plate boundary in their evaluation of seismic hazard in Alaska. But, as they acknowledged, the real situation may be more complex; the 1964 earthquake may have propagated westwards across several adjacent segments of the Alaska subduction zone. If these segments consistently rupture in unison, then their seismic assessment is valid. If the segments primarily rupture independently, however, then the recurrence and magnitude of great earthquakes in southern Alaska need to be reevaluated.

No complete model of the tectonic structure of the Alaska subduction zone yet exists, but accumulating evidence suggests that the part of the plate boundary that slipped in 1964 likely comprises 3 segments. Pulpan and Frohlich (1985) initially named these the southern, central, and northeastern 
blocks, but there is still no consensus on their limits or nomenclature. We have adopted the 3 -segment model as a working hypothesis, and refer to them as the Prince William Sound (PWS), Kenai (KEN), and Kodiak-Katmai (KOKA) segments (Figure 1).

The Prince William Sound segment comprises that section of the Alaska megathrust where the lower crust of the Yakutat terrane is welded to the underlying Pacific plate (Brocher et al. 1994). This composite slab is being subducted under the North America plate beneath Prince William Sound. The shallow dip $\left(3-4^{\circ}\right)$ of the subducting plate beneath the inner continental shelf is likely a product of the buoyancy of this mafic terrane. The 1964 earthquake nucleated here, and seismological investigations (Christensen and Beck 1994) and inversions of tsunami and geodetic data (Johnson et al. 1996) show that seismic slip was greatest in this area, likely as a result of higher coupling with the overlying plate.

The eastern boundary of the PWS segment coincides with the eastern limit of the 1964 rupture zone. This margin is marked by an absence of Wadati-Benioff Zone (WBZ) seismicity (Stephens et al. 1984). This "aseismic front" likely represents a tear or other discontinuity (the Yentna lineament of van Wormer et al. [1974]) in the subducting slab, effectively terminating eastward propagation of plate-boundary earthquakes. The western margin is more difficult to delineate. Although Brocher et al. (1994) contend that the sandwiched Yakutat terrane pinches out in the vicinity of the coastline, Ferris et al. (2003) speculate that the low-velocity zone they image to the east of Mt. McKinley represents the down-dip extension of this terrane. They note that if the inferred southern boundary of the terrane is extrapolated in the direction of plate convergence, then the down-dip extent lies at $100 \mathrm{~km}$ depth near Mt. McKinley. The subduction of continental terrane fragments in the area to the east of Mt. McKinley may also explain the absence of volcanic activity in this area.

Offshore, our proposed boundary between the PWS and KEN segments lies to the west of the magnetic anomaly on the continental shelf that may form the subducted southern margin of the Yakutat terrane (Griscom and Sauer 1990; Brocher et al. 1994). Onshore, we draw the boundary between the PWS segment and the KEN segment along the extrapolated western margin of the Yakutat terrane (Figure 1). This boundary neatly divides disparate regions of pre-1964 seismicity and post-1964 deformation on the Kenai Peninsula (Freymueller et al. 2000; Doser et al. 2004). Areas to the east currently display strong plate coupling, as indicated by crustal shortening and rapid post-seismic uplift (Figure 1).

Measurements in the aftermath of the 1964 earthquake and more recent investigations of seismic slip indicate that the KEN segment was only weakly coupled during the 1964 earthquake. The upper plate in this segment is currently moving trenchward (Figure 1) and is uplifting very slowly (Freymueller et al. 2000). The area down-dip of the 1964 rupture zone is undergoing rapid post-seismic creep (Freymueller et al. 2000). All of these indicators suggest that the plate interface in this segment is only weakly coupled at the present time (Freymueller et al. 2000).

We place the boundary between the KEN and KOKA segments midway between the western end of the Kenai Peninsula and the Kodiak Archipelago (Figure 1), but its precise location is poorly constrained. Onshore, the boundary is marked by a $20^{\circ}$ change in the strike of the WBZ (Ratchovski and Hansen 2002), a concomitant adjustment in the orientation of the volcanic arc (Marsh 1979) and a change in eruptive products and vent spacing (Kay et al. 1982; Kienle and Swanson 1983). Given that our analysis simply compares geological and archaeological records in terrestrial areas on either side of the boundary, the precise location of this boundary beneath the continental shelf is not criti$\mathrm{cal}$, and we consequently generalize it as shown in Figure 1. 
The western limit of our proposed KOKA segment follows the boundary between the 1964 and 1938 $\left(\mathrm{M}_{\mathrm{w}}=8.2\right)$ rupture zones. This boundary is approximately concordant with the down-dip projection of the Aja fracture zone (von Heune et al. 1999), and is marked in the upper plate by an offset in the volcanic arc (Marsh 1979), likely as a result of a change in the dip of the subducting plate (Estabrook et al. 1994). No major earthquake has ruptured across this boundary in the last $200 \mathrm{yr}$ (Estabrook et al. 1994), although Soloviev (1968) and Davies et al. (1981) suggest that 2 great earthquakes in 1788 ruptured the Kodiak segment along with the Alaska Peninsula and Shumagin segments to the west of the 1964 rupture zone. Crustal shortening is lower at sites in the KOKA segment than sites at similar distances from the convergent margin in the PWS segment, indicating that interplate coupling in the latter area is stronger (Figure 1).

\section{GEOLOGICAL EVIDENCE OF PLATE-BOUNDARY EARTHQUAKES}

In the aftermath of the 1964 earthquake, scientists associated with the United States Geological Survey (USGS) demonstrated that the spatial extent of fault rupture could be estimated from geological evidence of coseismic land-level change (Plafker 1965, 1969). Concomitant changes in local relative sea level allowed USGS investigators to document the magnitude of the deformation by measuring changes in the elevation of coastal biotic communities relative to tidal limits. Such evidence may be preserved in the sedimentary record and can be used to reconstruct the incidence of prehistoric plate-boundary earthquakes.

In areas close to the convergent margin, the upper plate was uplifted during the 1964 earthquake (Plafker 1965, 1969). In coastal areas exposed to severe wave action, the marine platform that developed during the preceding interseismic period was in some instances raised beyond the reach of the waves. Radiocarbon dating of organic materials in beach deposits or in the overlying terrestrial deposits on sequences of these relict marine terraces furnished an estimate of earthquake recurrence (Plafker and Rubin 1978). In more sheltered areas, such as lagoons and deltaic foreshores, great earthquake frequency can be established by dating the abrupt contacts between uplifted tidal flat deposits and overlying marsh or forest soils (Plafker et al. 1992).

In areas further removed from the plate boundary, the 1964 earthquake produced instantaneous subsidence (Plafker 1965, 1969). This is registered in many low-energy intertidal environments by an abrupt contact between the preseismic peaty soil and the tidal-flat mud that was deposited in the aftermath of subsidence. Earthquake recurrence is determined in these environments by dating sequences of peat-mud couplets in the sedimentary record.

The search for evidence of paleoseismic activity in southern Alaska in the aftermath of the 1964 Alaska earthquake by the USGS has been supplemented in the last few decades by investigations at more than 30 sites (Figure 2). We used these data to develop a great earthquake sequence for each site. We assume that all sedimentary contacts imputed to be of tectonic origin were correctly assigned. ${ }^{14} \mathrm{C}$ ages associated with gradual contacts and low-precision ages (quoted errors $>150 \mathrm{yr}$ ) were rejected. Out-of-sequence ages and repetitive-sequence ages, often indicative of unstable sites such as slumped channel banks, were also eliminated from the database. We utilized published lithologic sequences and local crustal deformation patterns in the 1964 earthquake to determine the direction of land-level change at a site. Ages were then categorized as maximal (pre-earthquake) or minimal (post-earthquake). The resultant database is presented in Appendix A.

Most of the ages in the database are derived from bulk samples of peat taken immediately below the upper contact of a buried marsh or forest soil in areas inferred to have been subject to repeated coseismic subsidence. Peat accumulation in these subarctic marsh environments is relatively slow, 


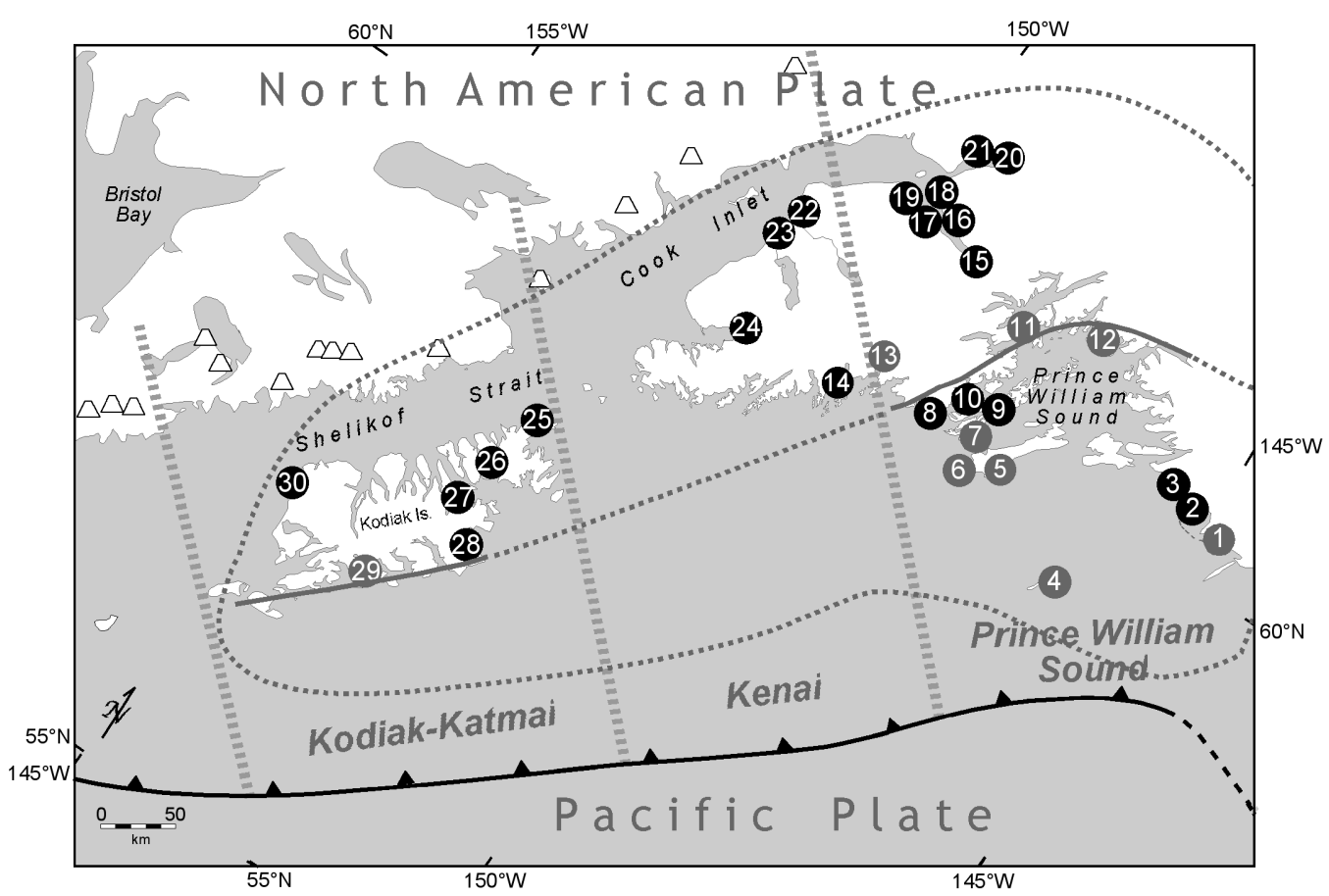

Figure 2 Sites in southern Alaska displaying geological evidence of abrupt prehistoric sea-level change. Black circles indicate sites with reliable data used in this analysis. Sites and sources: Copper River delta: 1. Katalla (Richards 2000) and Cape Suckling (Plafker 1969); 2. Copper River delta (Reimnitz 1966; Plafker 1990; Plafker et al. 1992; Plafker and Rubin 1994); 3. Eyak River and Little Glacier (Reimnitz 1966); 4. Middleton Island (Plafker 1969; Plafker and Rubin 1978). Prince William Sound: 5. MacLeod Harbor (Plafker 1969); 6. Patton Bay (Plafker 1969); 7. Latouche Island (Plafker 1969); 8. Puget Bay (Chaney 1997); 9. Knight Island (Chaney 1997); 10. Nowell Point (Plafker 1969) and Junction Island (Chaney 1997); 11. Perry Island (Plafker 1969); 12. Columbia Bay (Plafker 1969), Kenai Fjords; 13. Seward (Plafker 1969); 14. Aialik Bay (Mann and Crowell 1996). Cook Inlet, Turnagain Arm: 15. Portage (Combellick 1991; Bartsch-Winkler and Schmoll 1992); 16. Girdwood (Combellick 1991, 1993; Bartsch-Winkler and Schmoll 1992; Hamilton and Shennan 2005a); 17. Hope (Bartsch-Winkler and Schmoll 1992); 18. Ocean View, Anchorage (BartschWinkler and Schmoll 1992; Hamilton et al. 2005) 19. Chickaloon Bay (Combellick 1991; Bartsch-Winkler and Schmoll 1992; Combellick and Reger 1994). Cook Inlet, Knik Arm: 20. Palmer Hay Flats (Combellick 1991); 21. Goose Bay (Combellick 1991; Combellick and Reger 1994). Cook Inlet, Kenai Peninsula: 22. Kenai River Flats (Combellick and Reger 1994; Hamilton and Shennan 2005b); 23. Kasilof River Flats and 24. Fox River Flats (Combellick and Reger 1994). Kodiak Archipelago: 25. Shuyak Island; 26. Afognak Island; 27. Anton Larsen Bay; 28. Chiniak Bay; 29. Sitkalidak Island; 30. Sturgeon Lagoon (sites 25-30: Gilpin 1995).

and the quoted mean ${ }^{14} \mathrm{C}$ age may therefore predate the earthquake by several decades. In these circumstances, trees or marsh plants killed by sudden salt-water immersion more accurately indicate the age of the subsidence event, and ${ }^{14} \mathrm{C}$ ages on tree stumps or plant macrofossils were therefore preferred over peat ages at sites where both were available.

Because of the slow rate of accumulation of organic matter, the basal peat horizons on uplifted marine surfaces yield mean ${ }^{14} \mathrm{C}$ ages that may postdate the uplift event by several decades, but in this case, ages from buried tree stumps (commonly spruce or hemlock in southern Alaska) are a less accurate indicator of the age of the earthquake. This is a function of the fact that coniferous trees represent a late stage in the ecological succession on the newly uplifted surfaces. No colonization by spruce or hemlock seedlings had taken place, for example, on the tidal flats at the Copper River delta that were raised above the high tide limit some $30 \mathrm{yr}$ earlier (Thilenius 1990, 1995). Studies of suc- 
cessional sequences on deglaciated substrates in southern Alaska (Crocker and Major 1955) suggest that the development of mature conifers on the Copper River delta may take about a century. A comparison of bulk peat ages with ${ }^{14} \mathrm{C}$ ages on the outer rings or roots of tree stumps at the same stratigraphic level in areas of coseismic uplift indicates that the latter are on average about 80-120 $\mathrm{yr}$ younger than the peat. To incorporate this lag into the ${ }^{14} \mathrm{C}$ age, we added $100 \mathrm{yr}$ to the quoted mean ${ }^{14} \mathrm{C}$ ages of tree stumps in horizons immediately overlying beach sand or intertidal mud.

The 100-yr correction was applied only in those cases where the stratigraphic position of the tree stump could be surmised from the description in the original field report. Although trees in coastal forests die from a variety of natural causes, in some cases death may be linked to later phases of the great earthquake tectonic cycle. On the Copper River delta, for example, surface areas that are raised during a great earthquake gradually subside into the intertidal zone during the interseismic phase of the earthquake cycle. As the surface drops below the high-tide limit, trees growing on the surface die and peat deposition ceases as marsh plants are killed by salt-water exposure. Thus, a relict tree stump at or below a gradational contact between peat and tidal flat mud does not indicate a seismic event, and these ages were eliminated from the database.

The corrected ${ }^{14} \mathrm{C}$ ages were converted to the sidereal calendar using the IntCal $98{ }^{14} \mathrm{C}$ calibration data set of Stuiver et al. (1998). Probability density functions (PDFs) of individual calibrated ages (based on 50-yr intervals) were calculated from annual probability data generated by the CALIB 4.3 program (Stuiver and Reimer 1993). The PDFs of maximal and minimal ages bracketing inferred paleoseismic events were calculated using the minimal weighted range overlap procedure recommended by Biasi and Weldon (2003). This method estimates the true age of an event dated by multiple calibrated PDFs as $\min \left(E_{1}(t), E_{2}(t), \ldots E_{n}(t)\right)$, where $n$ is the total number of maximal or minimal ${ }^{14} \mathrm{C}$ ages constraining event $E$.

A plot of the resultant constraining PDFs (Figure 3) shows a complex array of potential earthquakebracketing ages. Although we recognize that even high-precision accelerator mass spectrometry (AMS) ages on in situ material at lithological contacts that can be unequivocally ascribed to coseismic crustal warping cannot prove that buried marsh soils at sites along hundreds of kilometers of coastline were submerged during a single great earthquake (Nelson 1992), we infer that concordant ages at neighboring sites are likely a product of the same event (or a series of closely spaced events). Conversely, discordant ages at neighboring sites are likely a product of independent ruptures, the geographical limits of which may coincide with segmentation of the subducting plate.

In addition to the great earthquake sequence derived from this analysis (Figure 3), we plot the chronology (2- $\sigma$ ranges) developed by Plafker and Rubin (1994) from ages on post-seismic deposits at the Copper River delta. The raw ${ }^{14} \mathrm{C}$ ages associated with coseismic deformation from the 2 most recent earthquakes (prior to 1964) at this site were published by Plafker et al. (1992), and are incorporated into our PDF analysis in Figure 3; the raw ${ }^{14} \mathrm{C}$ ages of earlier events have not yet been published.

\section{CHRONOLOGY OF GREAT EARTHQUAKES AT THE ALASKAN SUBDUCTION ZONE}

The penultimate great earthquake at the Copper River delta, which occurred about $800 \mathrm{yr}$ ago, is recorded at sites extending westward from the delta to the central coast of the Kenai Fjords National Park (Mann and Crowell 1996), and northward into upper Cook Inlet (Combellick 1991, 1993; 1994; Combellick and Reger 1994; Hamilton and Shennan 2005a,b; Hamilton et al. 2005). There is, however, no evidence that this earthquake propagated along the plate boundary to the west of this area (Figure 3). 


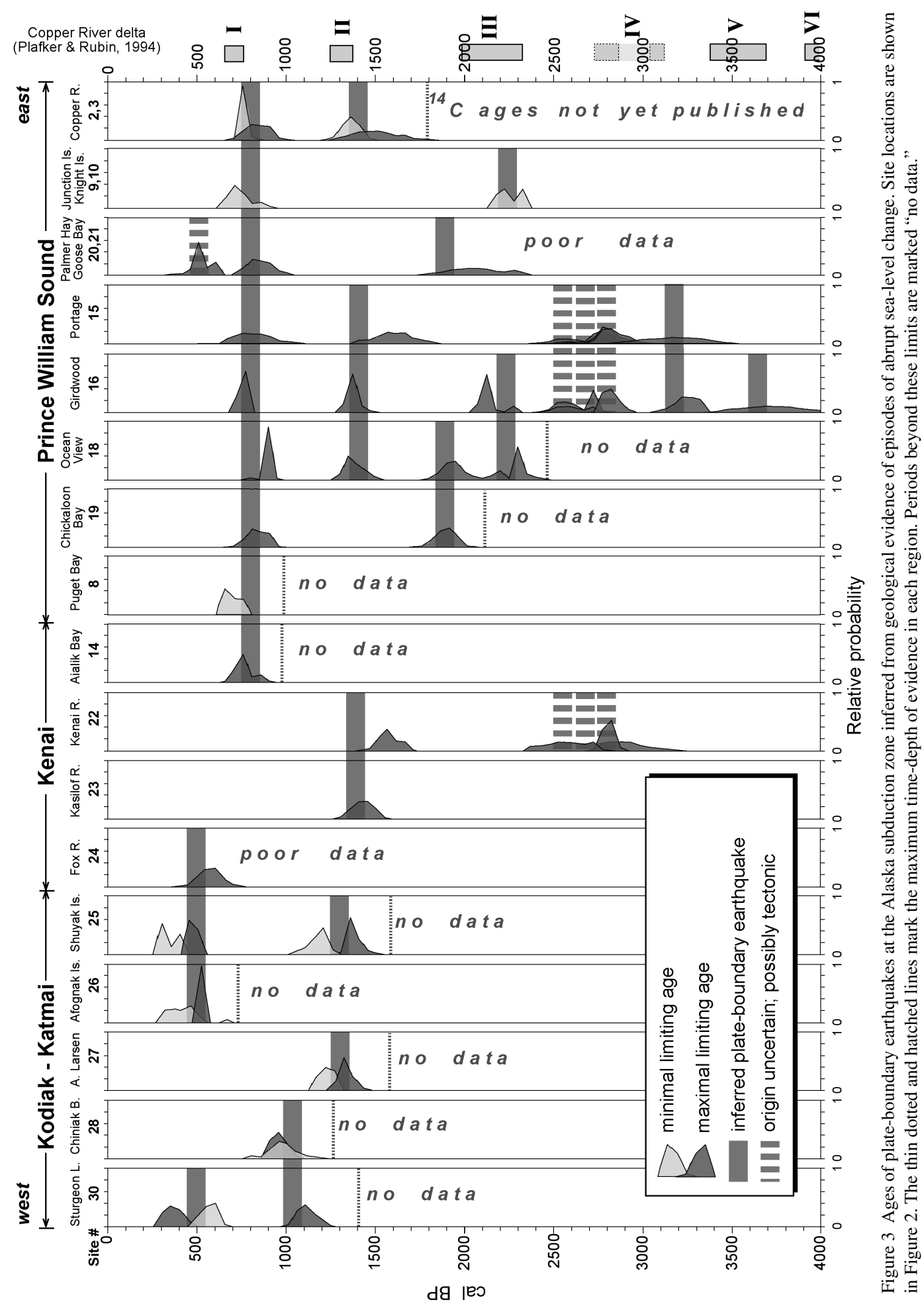


The plate boundary in the western area (i.e. the Kodiak Archipelago) appears to have slipped most recently about 500 yr ago (Figure 3). Gilpin (1995) dates this event to about AD 1550, slightly later than our estimate. This rupture may have extended eastwards to Fox River Flats on the western Kenai Peninsula (Figure 3), but the sudden sea-level change recorded at Palmer Hay Flats and Goose Bay in Knik Arm in upper Cook Inlet at approximately the same time is puzzling.

There is localized evidence of land-level change on Kodiak Island about 1000 cal BP, but we concur with Gilpin (1995) that the previous great earthquake at the western end of the 1964 rupture area likely occurred about $1300 \mathrm{yr}$ ago (Figure 3). Geological evidence of crustal deformation around this time is found from eastern Kodiak Island to the central part of the Kenai Peninsula.

This event may be contemporaneous with, or may have occurred shortly after, the antepenultimate earthquake (event "II" in the Plafker and Rubin [1994] chronology) recorded at the Copper River delta (Figure 3). Ages on uplifted tidal flats there and relict stumps in Prince William Sound and Puget Bay—along with buried marsh soils in Turnagain Arm, Kenai, and Kasilof River deltasshow that this earthquake occurred about $1400 \mathrm{yr}$ ago (Figure 3).

According to Plafker and Rubin (1994), the preceding coseismic deformation event at the Copper River delta (their "III"; Figure 3) occurred about, or shortly before, 2000 to 2300 yr ago. There are buried peats dating from about 2200-2300 yr ago at Ocean View and Girdwood in Turnagain Arm, and relict stumps from this period in Prince William Sound (Figure 3), which suggest that a great earthquake likely ruptured at least the eastern segment of the Alaska megathrust at this time. At Ocean View, however, this peat is overlain by a marsh soil with an abrupt upper contact that dates from about $1900 \mathrm{yr}$ ago (Figure 3). A buried soil of about the same age occurs on the western shore of Turnagain Arm, at Chickaloon Bay. The absence of evidence for this younger event from southern Turnagain Arm (Girdwood, Portage) and the Copper River delta is puzzling.

Similar uncertainties surround uplift event IV (Figure 3) at the Copper River delta. According to Plafker and Rubin (1994), this event occurred about 2800 to $3000 \mathrm{yr}$ ago, but the AMS ${ }^{14} \mathrm{C}$ ages that they report from this event form 2 distinct subgroups (2750-2880 cal BP and 3050-3130 cal BP). Buried soils at Girdwood and Portage that date from 3100-3200 yr ago (Combellick 1994) suggest that a great earthquake ruptured at least the eastern part of the Alaska subduction zone at this time. At some sites in southern Turnagain Arm, the buried soil from this event is overlain by 3 soils that predate event III at the Copper River delta. At both Girdwood and Portage, the oldest of these 3 soils contains tree stumps and detrital wood, and dates to $\sim 2800 \mathrm{yr}$ ago; i.e. akin to the younger cluster of AMS ages associated with event IV at the Copper River delta. The 2 younger soils are muddy peats and date from $\sim 2500-2700 \mathrm{yr}$ ago. An equivalent, essentially coeval stratigraphic sequence has been described at the Kenai River delta (Combellick and Reger 1994).

Given that the recurrence interval of inferred great earthquakes at the Alaska megathrust in the last $2500 \mathrm{yr}$ averages about $700 \mathrm{yr}$ (Figure 3), it seems unlikely that a segment of the subduction zone would rupture 3 times in $\sim 300$ yr. Do any of these 3 buried soils result from regional subsidence during a plate-boundary earthquake? Alternatively, are any the product of local movements on upper-plate faults, or do 1 or more represent non-tectonic forcings? For example, did isostatic loading or unloading during a Neoglacial period trigger rapid changes in relative sea level on the Kenai Peninsula?

The oldest coseismic uplift event recorded at the Copper River delta in the last $4000 \mathrm{yr}$ dates from prior to 3400-3700 yr ago (Plafker and Rubin 1994; "V"). It is probably correlative with the lowest 
peat at Girdwood, which is dated by a single, low-precision ${ }^{14} \mathrm{C}$ age (Combellick 1991) to about $3500-3700$ cal BP.

The geological data that are available for reconstructing the incidence of great earthquakes at the Alaska subduction zone are variable in quality and time-depth, and many questions remain about the age and extent of these events. While these uncertainties will almost certainly be reduced by further exploration of sensitive coastal sites, there is an untapped source of information that may clarify the paleoseismic record of this subduction zone. That data source consists of the stratigraphic records and ${ }^{14} \mathrm{C}$ chronologies of the archaeological sites that have been excavated around the margins of the Gulf of Alaska over the course of the last several decades.

\section{THE ARCHAEOLOGICAL RECORD OF PALEOSEISMIC EVENTS IN SOUTHERN ALASKA}

The archaeological record from the Gulf of Alaska holds considerable promise as a source of paleoseismic information, because the highest density of Alaskan native settlement was located along the shore, reflecting the maritime focus of the economy and the relative ease of travel by sea.

Coastal villages consisted of groups of semi-subterranean houses near the water, usually only a few meters above sea level (m asl). For example, the village at Palugvik on the south shore of Hawkins Island, in Prince William Sound, was situated on 2 tombolos bracketing a small bay (de Laguna 1956); and the village at Settlement Point on Afognak Island was located on the shore of a tidal lagoon (Figure 4; Saltonstall and Carver 2002). Not only were the people living in these locations at risk during a great earthquake from tectonic and landslide tsunamis, but villages may have been uninhabitable for decades after a great earthquake due to abrupt changes in relative sea level and loss of local food resources.

Extensive midden deposits, composed largely of discarded shellfish remains and other domestic refuse, mark the sites of former large villages such as Palugvik. Scattered house pits with thinly strewn cultural debris mark small villages and seasonal camps (de Laguna 1956, 1975; Mobley et al. 1990; Haggarty et al. 1991; Erlandson et al. 1992; Crowell 2000).

As Knecht notes, the middens of prehistoric coastal villages in the Kodiak Archipelago reveal "long periods of relative stasis and very brief periods of rapid change in an overall pattern of punctuated equilibrium" (1995:745). The most severe changes are marked by depositional breaks and culturally sterile strata, which indicate partial or complete abandonment of villages. The same pattern applies more broadly to phase transitions across the Gulf of Alaska (Erlandson et al. 1992; Mills 1994; Crowell et al. 2003). Temporal gaps in site occupation in this area may reflect cultural factors, such as warfare, or environmental causes, such as volcanic eruptions, river floods, global sea-level changes, local glacier advances, diseases, or loss of local food resources.

We suggest that the dominant cause of widespread village abandonment around the margins of the Gulf of Alaska was likely to have been plate-boundary earthquakes. The great Sumatra earthquake of 26 December 2004, for example, demonstrated that tectonic tsunamis, particularly when enhanced by coseismic subsidence, have tragic consequences for the people living on neighboring coasts. The survivors may move elsewhere - so both the date of initial occupation and of temporary or final abandonment of a settlement can be potential sources of paleoseismic information. Three native villages in the Kodiak Archipelago, for example, were severely damaged as a result of the subsidence and tsunamis generated by the 1964 earthquake. Two of these villages (Afognak, Kaguyak) were abandoned, and the survivors moved elsewhere (Plafker and Kachadoorian 1966; Saltonstall and Carver 2002). 


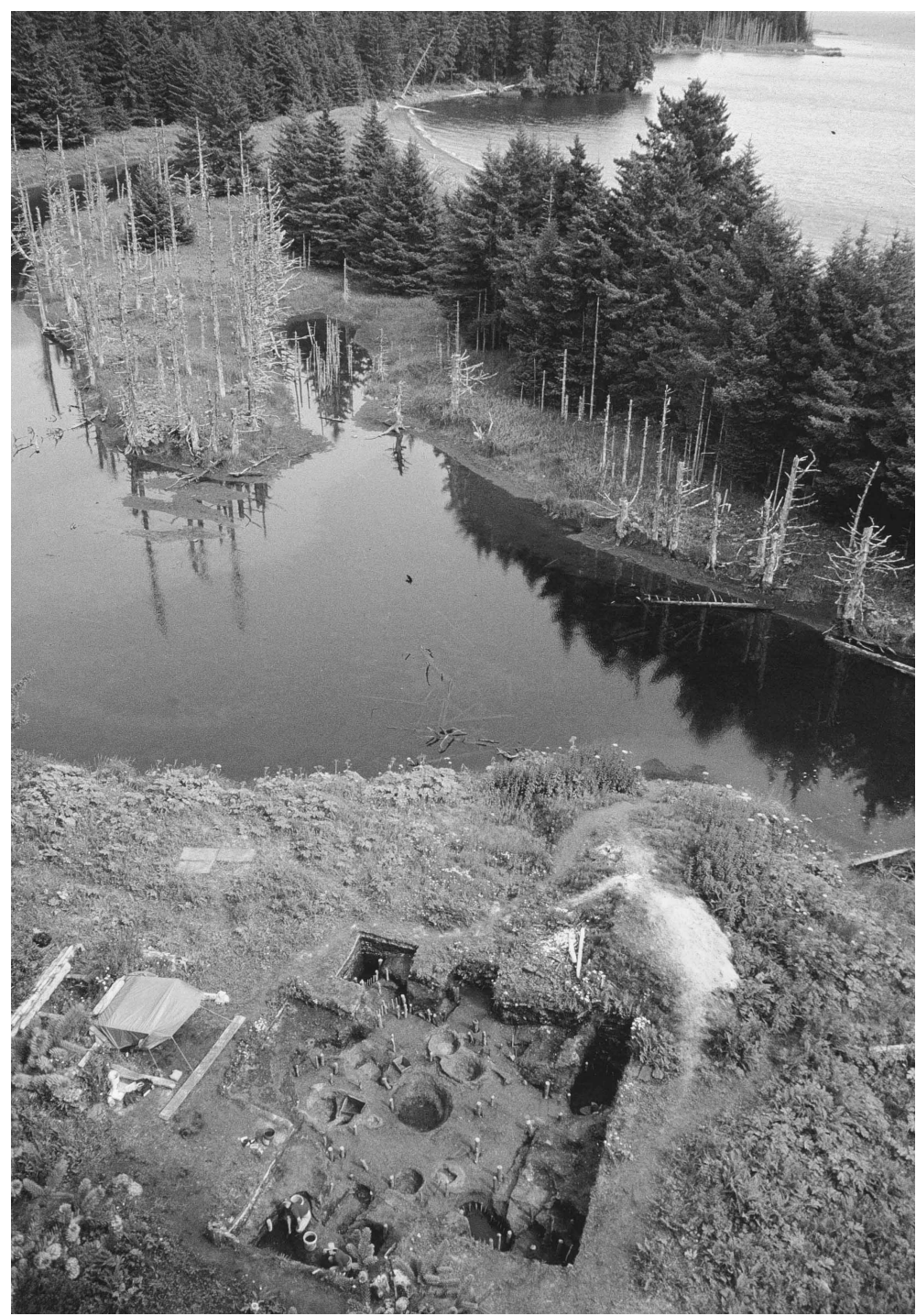

Figure 4 Excavation of a semi-subterranean house at the Settlement Point (AFG-015) archaeological site on Afognak Island. The dead spruce trees on the shore of the tidal lagoon were killed by salt-water exposure following $>1 \mathrm{~m}$ of subsidence during the great earthquake of 1964. Photograph courtesy of Patrick Saltonstall.

In areas of net tectonic uplift, settlements may form a progressive, punctuated series on a staircase of relict back-beaches above the present shoreline. In contrast, coseismic subsidence may lead to flooding and erosion of old village sites. The archaeological record in these areas will consequently have limited time-depth as a result of site attrition (Crowell and Mann 1998; Saltonstall and Carver 2002).

This is not the first attempt to link paleoseismic and archaeological records in southern Alaska. For example, Winslow and Johnson state that there is "an inverse correlation between prehistoric settlement size and numbers and geologically inferred earthquakes" (1989:314) in the Shumagin Islands, which lie about $400 \mathrm{~km}$ to the west of the 1964 rupture. They argue that the size and number of sites 
were much reduced in the aftermath of great earthquakes, which produced gaps of 200 to $400 \mathrm{yr}$ in the occupation sequence. Similarly, Maschner (1999) notes that there is a gap in the occupation of the lower Alaska Peninsula about 2200 to $2500 \mathrm{yr}$ ago that is attributable to a major seismic event in the region, and Saltonstall and Carver (2002) show the impacts of previous great earthquakes on the village site at Settlement Point on Afognak Island. In addition, the transitions between cultural phases in southern Alaska may be a product of the socio-economic impacts of great earthquakes (Maschner 1995).

Whereas previous investigators have primarily attempted to integrate seismic and cultural history in Alaska to explain shifts in site tenancy and cultural traditions, our objective is the opposite; we contend that the rich archaeological archive of southern Alaska can shed light on the paleoseismic history of the region. This is a new approach in this region, and our interpretation of evidence is often speculative, but the success of this approach as a complement to geological investigations of paleoseismic activity at other convergent margins (e.g. Hutchinson and McMillan 1997; Goff and McFadgen 2001) is sufficient reason to apply it in southern Alaska.

The geoarchaeological approach to paleoseismology is rooted in the premise that changes in site tenancy as a result of seismic activity can be inferred from midden stratigraphy and from ${ }^{14} \mathrm{C}$ ages on cultural deposits (Hutchinson and McMillan 1997). If a village is abandoned in the immediate aftermath of a great earthquake, the midden should reveal stratigraphic evidence of rapid land-level change or inundation by high-energy waves. Where such direct evidence is absent, earthquakerelated abandonment may be inferred if hiatuses in occupation are concurrent with known paleoseismic events.

Archaeological excavations normally expose only a small fraction of the village area, so we are commonly forced to derive site-wide conclusions from a limited spatial sample. Accumulation of material associated with houses, hearths, and food waste is evidence of site occupation, and closely spaced or overlapping ${ }^{14} \mathrm{C}$ ages derived from this cultural material likely reflects continuous occupation. Archaeologists rarely date culturally sterile strata in middens, and periods of abandonment must therefore generally be interpolated from limiting ages on bracketing cultural units. These periods may be apparent as gaps in the ${ }^{14} \mathrm{C}$ record, or veiled under the tails of ${ }^{14} \mathrm{C}$ age probability distributions associated with periods of occupation. Variation in the overall probability distribution of ${ }^{14} \mathrm{C}$ ages at a site or in a local area can thus serve as a proxy index for site activity.

In order to construct such a proxy, we compiled evidence from published and unpublished reports from excavated archaeological sites in the area that experienced abrupt land-level changes in 1964. We noted evidence of sterile layers (e.g. beach gravels, tephras, marsh peat, and forest soils) in midden stratigraphy, and developed a database of ${ }^{14} \mathrm{C}$ ages from these reports. These data were supplemented with information from an archaeological database covering the central and western parts of the 1964 earthquake area (http://faculty.washington.edu/fitzhugh/FitzHome.html).

We retained only those ${ }^{14} \mathrm{C}$ ages accepted by the original excavators (a few exceptions are noted) that were obtained on samples of charcoal or other terrestrial organics (thus avoiding the oceanic reservoir effect associated with marine organisms), and which had quoted errors of $<150$ yr. Elevated sites ( $>15 \mathrm{~m}$ asl) and those dating from the historic or protohistoric period $\left(<300{ }^{14} \mathrm{C} \mathrm{yr} \mathrm{BP}\right)$ were also deleted from the database. The sites in each segment were divided into 2 groups ("outer" and "inner" coastal sites), based on our perception of the relative magnitude of the seismic hazard. Sites on outer coasts are at greater risk from tectonic tsunamis than those in more sheltered locations. The overall distribution of dated prehistoric sites is shown in Figure 5. The complete archaeological database is listed in Appendix B, and the maps in Appendix C show the locations of the dated sites in each segment. 


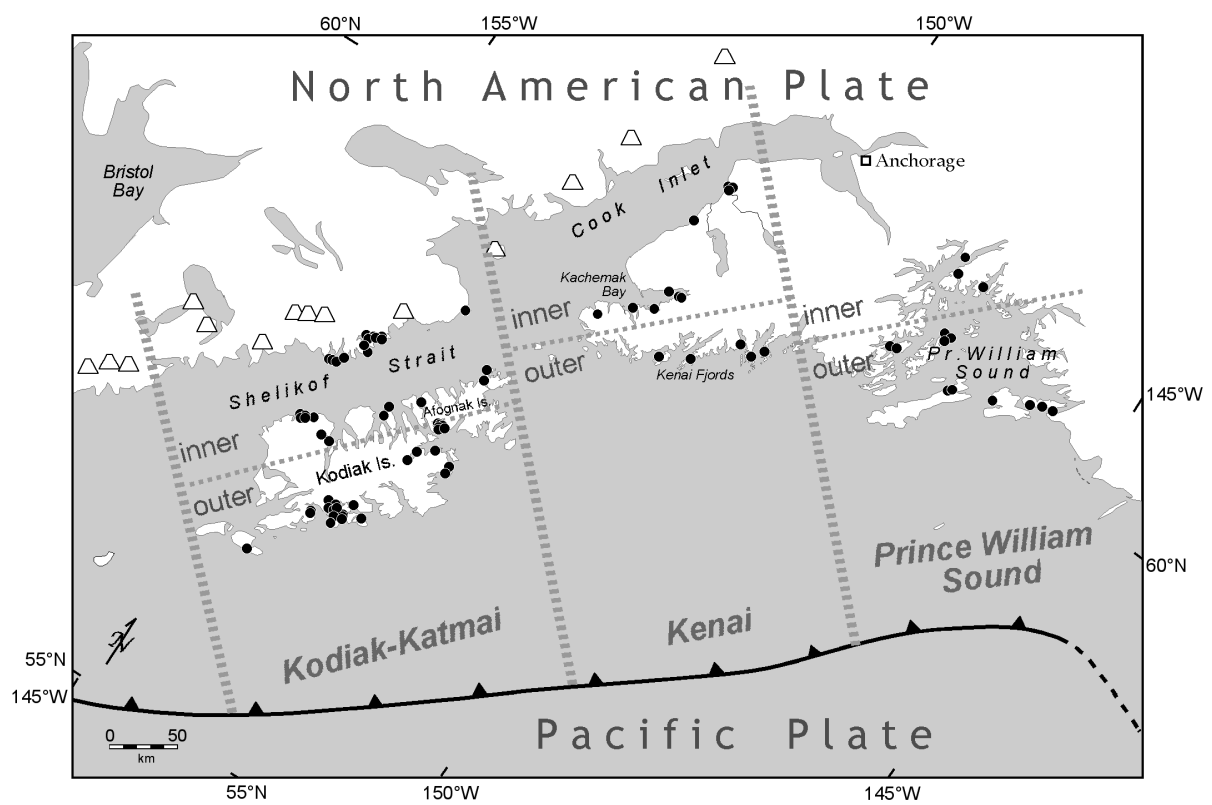

Figure 5 Locations of dated prehistoric coastal archaeological sites in southern Alaska relative to the Prince William Sound, Kenai, and Kodiak-Katmai tectonic segments. Sites in "outer" coastal locations have higher relative exposure to seismic and tsunami hazards.

Calibrated ages were derived from the ${ }^{14} \mathrm{C}$ ages using CALIB 4.3 (Stuiver and Reimer 1993). The calibrated age distributions from each site are graphed in Appendix D, and detailed site descriptions can be found in Hutchinson and Crowell (2006). Figure 6 shows the relative frequency distribution of calibrated ages (averaged over 50-yr intervals) in each group of sites. Probability density functions (PDFs) of all the calibrated ages from each group of sites (binned in 50-yr intervals) were calculated from annual data generated by CALIB 4.3. Because of the inherent non-linearity of the ${ }^{14} \mathrm{C}$ age-sidereal age relationship, we also calculated PDFs for each group of sites using randomly generated ${ }^{14} \mathrm{C}$ ages with the same relative frequency of ages per millennium, and the same distribution of error terms as in the raw data. The $90 \%$ confidence intervals for these random PDFs were calculated from 5 trial runs.

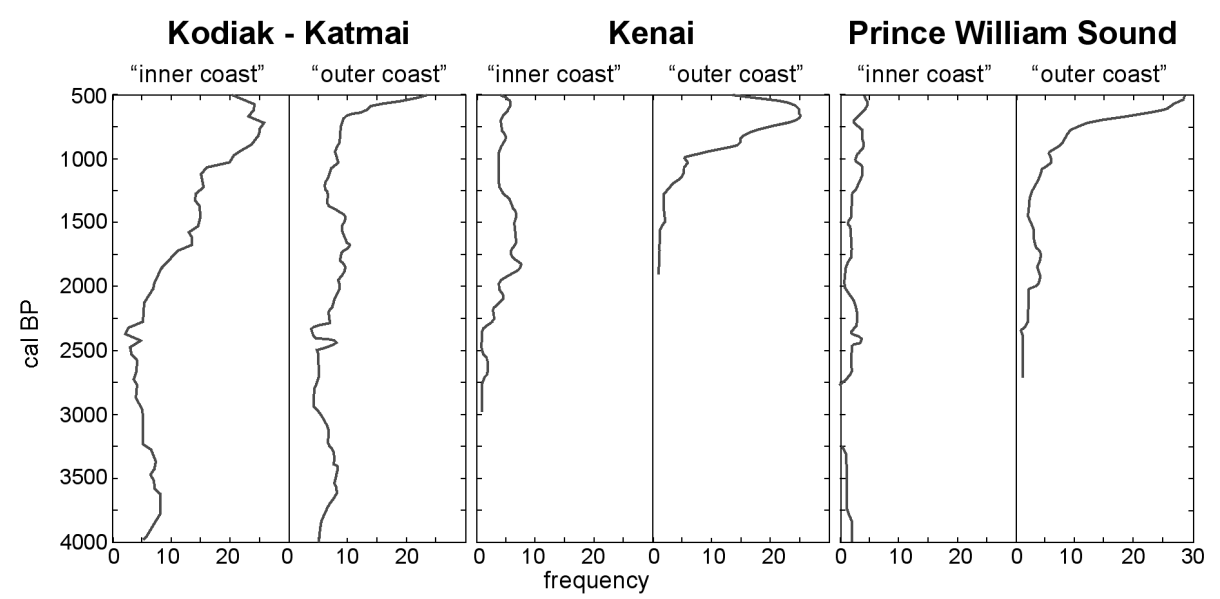

Figure 6 Mean frequency of composite calibrated ${ }^{14} \mathrm{C}$ ages in 50-yr intervals, from prehistoric "inner" and "outer" coastal archaeological sites in the Kodiak-Katmai, Kenai, and Prince William Sound tectonic segments. 
We argue that extreme variations of the observed value relative to the mean random ("expected") distribution (Figure 7a) represent an index of activity within a group of sites. Abrupt increases may represent episodes of colonization or resettlement, whereas rapid decreases may indicate widespread abandonment of villages or seasonal camps in a region.

a

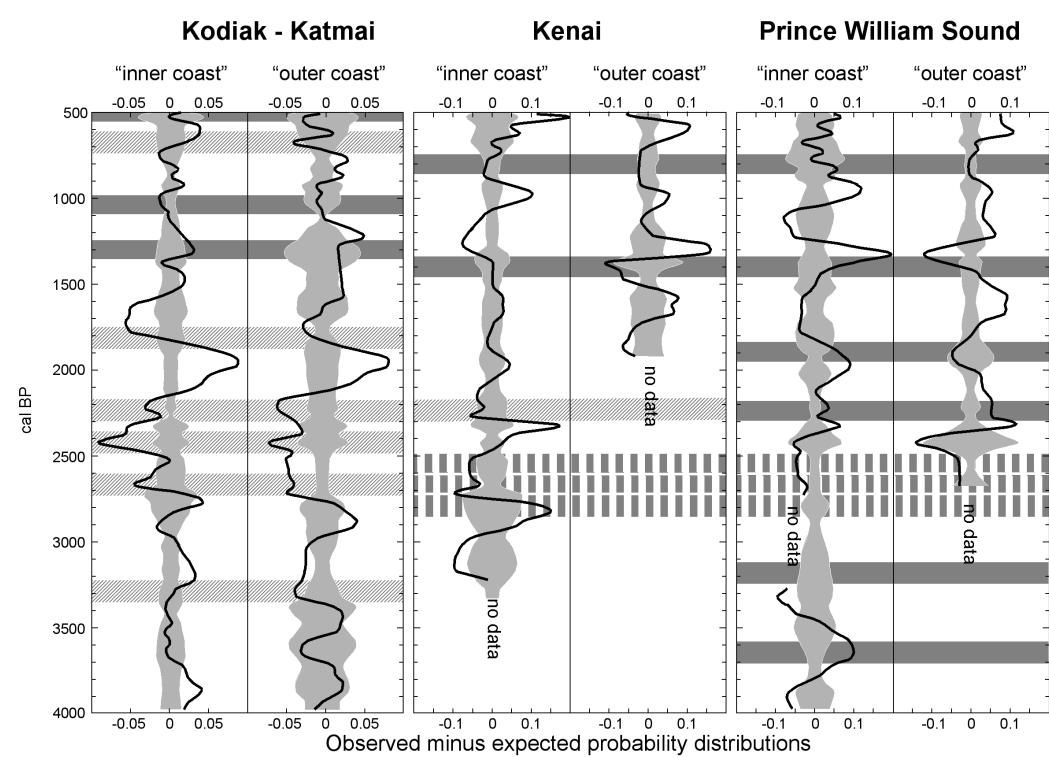

b

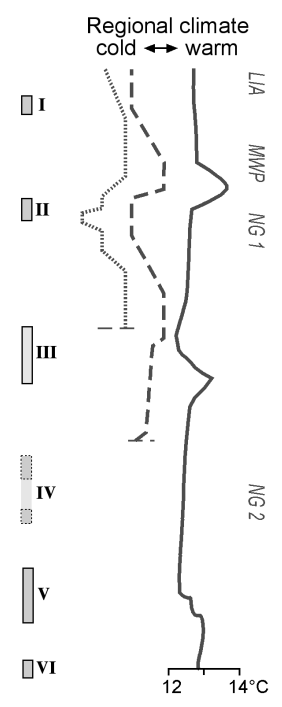

Figure 7 a) Variations in temporal probability distributions (black lines) of calibrated ${ }^{14} \mathrm{C}$ ages (binned in 50 -yr intervals) from archaeological sites in the tectonic segment-coastal exposure units relative to the mean of 5 random runs for that unit. The $90 \%$ confidence interval envelopes for the randomly generated data are shown in light gray. Dark gray horizontal lines are estimates of the ages of prehistoric plate-boundary earthquakes, as inferred from geological evidence; vertically striped horizontal lines are ambiguous events (see Figure 3). Obliquely hatched horizontal lines indicate inferred episodes of abandonment of native villages (see text) that may be attributable to plate-boundary earthquakes; b) Minimum ages of inferred plate-boundary earthquakes at the eastern end of Alaska subduction zone, from Plafker and Rubin (1994); c) Paleotemperature proxies from southern Alaska. Dotted line: lake geochemistry, Alaska Range (Hu et al. 2001); dashed line: glacial advances and retreats, Gulf of Alaska (Calkin et al. 2001); solid line: pollen assemblages (mean July temperature, ${ }^{\circ} \mathrm{C}$; Heusser et al. 1985). LIA = Little Ice Age; MWP = Medieval Warm Period; NG1 = Neoglacial 1; NG2 = Neoglacial 2.

\section{DISCONTINUITIES IN SITE OCCUPATION IN THE PRINCE WILLIAM SOUND SEGMENT}

The 17 precontact archaeological sites and site complexes that have been excavated in the area occupied by the PWS segment (Figure 5) have yielded $69{ }^{14} \mathrm{C}$ ages. The sites in the outermost part of the sound lie in the area that was uplifted during the great earthquake of 1964. The oldest sites in this area date from about $2500 \mathrm{yr}$ ago, but most ${ }^{14} \mathrm{C}$ ages postdate the penultimate earthquake at about $800 \mathrm{cal}$ BP (Figure 6). The site activity index from this area (Figure 7) shows only a modest downturn at this time, but the ${ }^{14} \mathrm{C}$ age distributions that fall in this period are derived from a single site (SEW-488; Appendix B). In contrast, a severe reduction in site activity occurred in the area about $1400 \mathrm{yr}$ ago, at about the time of the penultimate great earthquake.

Localized geological evidence in Turnagain Arm suggests that the previous great earthquake in the PWS segment occurred about $1900 \mathrm{yr}$ ago. The archaeological record from the outer coasts of Prince William Sound, however, suggests that this event had only a limited impact (Figure 7). The 
archaeological ${ }^{14} \mathrm{C}$ record prior to $2000 \mathrm{cal} \mathrm{BP}$ in this area is extremely meager, and no inferences can be drawn about site occupation or abandonment for this time period from this source.

Although dating control in the early prehistoric period is poor, the midden stratigraphy at sites with considerable time-depth suggests that great earthquakes may have had a strong influence on the history of settlement. At Palugvik, for example, a wooden artifact (P-173; Appendix B) dates an early occupation to $\sim 2300-2500$ cal BP; i.e. prior to the inferred plate-boundary earthquake that occurred $\sim 2200-2300$ cal BP. Frederica de Laguna, who excavated the Palugvik village site in the 1930s, rejected this date (de Laguna 1975), but we accept it on the basis of Yarborough and Yarborough's (1991) observation that the cultural materials are akin to artifact assemblages dating from this period at other sites in the area. This early prehistoric occupation is separated from a later component by a thin gravel layer, which might be the product of a tsunami generated by the great earthquake of 2200-2300 cal BP. This later occupation occurred in the interval between this event and the inferred great earthquake at $\sim 1400 \mathrm{yr}$ ago. The site was finally abandoned at about that time.

In addition, site SEW-440 on Eleanor Island "appears to have been occupied during 2 distinct time periods during the past 2 millennia" (Yarborough 1997:36). The stratigraphy of the test pits at this site also indicates a hiatus in site tenancy that lasted for several hundred years during the later period of occupation. The ${ }^{14} \mathrm{C}$ ages from this site can be grouped into 3 phases. The breaks between these phases correlate with inferred great earthquakes at $800 \mathrm{cal} \mathrm{BP}$ and $1400 \mathrm{cal} \mathrm{BP}$.

${ }^{14} \mathrm{C}$ ages from the intact part of the midden at SEW-488 on Knight Island suggest that the site was occupied only in the aftermath of the $800 \mathrm{cal}$ BP earthquake. Linda Yarborough (1997) notes that a thick organic deposit at the base of the site is interrupted by a sandy horizon. Although the origin of this horizon is unknown, bracketing ${ }^{14} \mathrm{C}$ ages from above ( $820 \pm 60 \mathrm{BP}$ [Beta-89048]) and below ( $910 \pm 90$ BP [Beta-89049] and $990 \pm 60$ BP [Beta-89050]) the sand layer imply that it may have been emplaced by the tsunami generated by the earthquake at $\sim 800 \mathrm{cal} \mathrm{BP}$.

The site occupancy pattern in the inner fjords of Prince William Sound is based largely on ${ }^{14} \mathrm{C}$ ages from the Uqciuvit village site (SEW-056), which lies on a sloping terrace just above a beach in the sheltered waters of Esther Passage. Fourteen of the $17{ }^{14} \mathrm{C}$ ages from this area are derived from this site. The site was initially occupied about $4400 \mathrm{yr}$ ago, but was apparently unoccupied from 3200 $2500 \mathrm{yr}$ ago, when local glaciers advanced to within $7 \mathrm{~km}$ of the site (Yarborough and Yarborough 1991).

A layer of gravel exposed in excavations near the beach separates 2 later occupations. The bracketing ${ }^{14} \mathrm{C}$ ages indicate that the gravel represents a beach formed following coseismic subsidence associated with the inferred great earthquake that occurred $\sim 1400 \mathrm{cal}$ BP. As the excavators of the site, however, note, "there is no evidence of a hiatus in occupation of the site corresponding with another earthquake about 850 years ago" (Yarborough and Yarborough 1991: 228). In fact, the activity index from Uqciuvit and the other sites in this area is almost a mirror image of the pattern from the outer coasts of Prince William Sound, with indications of enhanced activity at about the time of the great earthquakes (Figure 7). This suggests that sites in sheltered locations in the inner fjords, such as Uqciuvit, may have served as refuges for survivors displaced from villages in more exposed locations.

\section{DISCONTINUITIES IN SITE OCCUPATION IN THE KENAI SEGMENT}

Most of the excavated sites on the outer coast of the Kenai Peninsula (Figure 5) sit on relict beaches that appear to have formed in the aftermath of the penultimate earthquake about $800 \mathrm{yr}$ ago (Crowell 
and Mann 1998). Consequently, virtually all of the $36{ }^{14} \mathrm{C}$ determinations from the sites in the Kenai Fjords postdate the earthquake (Figure 6). Some bear witness to earlier occupations (SEL-188, XBS-030; Appendix B), but the pattern of occupation in the region prior to the $800 \mathrm{cal}$ BP earthquake cannot be reconstructed with any certainty, as few samples of older cultural materials have been dated. The ostensible downturn in site activity at the time of the great earthquake $\sim 1400 \mathrm{yr}$ ago (Figure 7) therefore cannot be reliably attributed to this event.

The geomorphic and archaeological impacts of the $800 \mathrm{cal}$ BP great earthquake are evident at several sites. At Bear Cove (XBS-030), for example, the uppermost ${ }^{14} \mathrm{C}$ sample from the lowest archaeological stratum indicates that this occupation ended between 920-680 cal BP (2- $\sigma$ limits, Beta170797; Appendix B). This house floor is overlain by a gravel lens that is considered to form part of an overwash fan deposited by storm waves reworking an old beach that subsided during the earthquake (Mason 2006). Two ${ }^{14} \mathrm{C}$ samples from the house floor above the gravel lens (Beta-67273, Beta-67274; Appendix B) date this occupation to 660-535 cal BP, which indicates that the Bear Cove site was likely not re-occupied until relative sea level stabilized a century or more after the earthquake.

Nine ages from the upper midden at McArthur Pass (SEL-188; Appendices B, C, D) indicate that this site, like XBS-030, was re-occupied $\sim 600-700 \mathrm{yr}$ ago. A slightly imbricated layer of granite slabs, which may be a cultural artifact or a tsunami lag deposit, separates the upper midden from underlying cultural strata. ${ }^{14} \mathrm{C}$ determinations from the base of the lower midden suggest that SEL188 was occupied for a short time $\sim 1600 \mathrm{yr}$ ago, and again — perhaps after a hiatus in the aftermath of an earlier great earthquake—about $1300 \mathrm{yr}$ ago.

The sites on the shorelines of Kachemak Bay lie $\sim 50 \mathrm{~km}$ arcward of the outer coast sites (Figure 5). Unlike the sites in the Kenai Fjords, however, only 1 of the 7 prehistoric sites that have been dated on the shores of the bay appears to have been settled in the aftermath of the 800 cal BP earthquake (SEL 027; Appendix B). Some sites (e.g. SEL-033 on Chugachik Island; Appendix B) have been occupied for much longer periods.

The settlement history of the bay shows several episodes of reduced activity in the last 3 millennia (Figure 7). The first of these began $\sim 1400 \mathrm{yr}$ ago. Although it is tempting to ascribe the apparent reduction in site activity to the great earthquake that occurred at about this time, the downturn is gradual, and may have had other causes. The second hiatus is concordant with the plate boundary earthquake at 2200-2300 cal BP, and the third appears to be coincident with the 2nd of the closely spaced events that date to $2500-2900 \mathrm{cal}$ BP.

The archaeological sites on the shores of central Cook Inlet ( $>300 \mathrm{~km}$ from the convergent margin; Figure 5) are camps established by Dena'ina people from the interior of Alaska within the last 600 yr (Reger 1987; Reger and Boraas 1996). Because of their limited time-depth, these sites contribute little to an analysis of great earthquake incidence and are not considered further.

\section{DISCONTINUITIES IN SITE OCCUPATION IN THE KODIAK-KATMAI SEGMENT}

The temporal pattern of prehistoric settlement on the outer coasts of Kodiak Island and its neighbors (Afognak, Sitkalidak, and the Trinity Islands) is constrained by $76{ }^{14} \mathrm{C}$ ages from 30 archaeological sites. According to the ${ }^{14} \mathrm{C}$ record (Figure 7), there have been 4 major downturns in site activity in this area in the last $4000 \mathrm{yr}$. These occurred approximately 700, 1900, 2700, and $3300 \mathrm{yr}$ ago. Other, minor reductions in site activity began $\sim 2300$ and 2500 yr ago. 
Settlement Point (AFG-015), a small village located on a tidal lagoon on the south shore of Afognak Island (Figure 4), illustrates the shifts in settlement patterns in this area that may be attributable to catastrophic earthquakes (Saltonstall and Carver 2002). Two ${ }^{14} \mathrm{C}$ ages $\left(570 \pm 60{ }^{14} \mathrm{C}\right.$ yr BP [Beta118330], and $620 \pm 50{ }^{14} \mathrm{C}$ yr BP [Beta-101551]; Appendix B) suggest that the oldest excavated house at the site (Figure 4 ) was built shortly after $650 \mathrm{cal}$ BP. The house sits on a beach that formed following coseismic subsidence. The apparent downturn in site activity that begins $\sim 700 \mathrm{yr}$ ago in the KOKA segment (Figure 7) suggests that the house may have been built a few decades after a great earthquake that was restricted to this segment of the plate interface.

The "inner coast" sites of the KOKA segment lie on the northern shores of Kodiak, Afognak, and Shuyak islands, and the Katmai coast on the northern margin of Shelikof Strait (Figure 5). The southern shores of the strait experienced moderate amounts of coseismic deformation and tsunami run-up in 1964, but land-level changes and tsunami run-up on the northern shore were negligible (Plafker 1969).

Almost $100{ }^{14} \mathrm{C}$ ages have been published from the testing or excavation of 30 prehistoric sites on this coast (Crowell and Mann 1996; Crowell et al. 2003). Most of the ${ }^{14} \mathrm{C}$ ages date occupations during the last $1500 \mathrm{yr}$, but a considerable number of ${ }^{14} \mathrm{C}$ determinations are available from earlier times.

The resultant probability distribution (Figure 7) correlates strongly with that from the outer coast of the KOKA segment, suggesting that changes in the temporal pattern of occupation had a common cause. We identify 3 major reductions in archaeological site activity on the inner coast (Figure 7), beginning at $\sim 1900,2500$, and $2700 \mathrm{cal} \mathrm{BP}$. The descriptions of midden stratigraphy in the archaeological literature, however, suggest that earthquakes and their attendant tsunamis have impacted some sites much more recently.

One such site is New Karluk (KAR-001), located on a spit at the mouth of Karluk Lagoon on the northwest coast of Kodiak Island. The 4-m-thick midden at this site overlies an old beach. The midden is comprised of old wooden house floors and collapsed sod roofs, plus food refuse. Eight ${ }^{14} \mathrm{C}$ ages indicate that the site has been occupied for about the last $800 \mathrm{yr}$. A 4-cm-thick layer of sterile gravel overlies the lowest cultural deposits (Jordan and Knecht 1988; Knecht 1995). Bracketing ages on successive floors of a single house (Beta-25599 and Beta-15016; Appendix B) indicate that the gravel (which the original excavators inferred to be a tsunami deposit) was emplaced about 600700 yr ago.

Tsunami deposits may also be preserved in the middens of abandoned villages on the Katmai coast. For example, a test pit in a 1-m-thick midden near Cape Gull (XMK-058) revealed a layer of beach cobbles up to $0.2 \mathrm{~m}$ thick between 2 occupation layers, the lower of which is also underlain by cobbles (Dekin et al. 1993). The basal cobble layer was deposited prior to $650 \mathrm{cal}$ BP (GX-17006/7 and GX-17008/9; Appendix B), and may be a relict beach or tsunami deposit. This may be correlative with the inferred tsunami deposits or beach facies at archaeological sites on the southern shore of Shelikof Strait. The upper beach cobble layer, which is bracketed by 2 split pairs of ${ }^{14} \mathrm{C}$ ages (GX17006/7 and GX-17008/9; Appendix B), dates from the interval between 510-650 yr ago, and may have been laid down by the tsunami associated with the inferred earthquake at about $500 \mathrm{cal} \mathrm{BP}$ (Gilpin 1995). 


\section{DISCUSSION AND CONCLUSIONS}

\section{Geological Evidence of Great Earthquakes}

Plafker and Rubin (1994) proposed a chronology of great earthquake incidence at the Alaskan subduction zone based on evidence of coseismic uplift from the Copper River delta, close to the eastern boundary of the 1964 rupture zone. They furnish a minimum age for each earthquake by dating organic materials deposited shortly after each episode of coseismic uplift. Our analysis of depositional sequences associated with coseismic deformation at other sites in the 1964 rupture zone suggests that the Copper River delta earthquake chronology is likely also applicable in Prince William Sound, adjacent parts of the Kenai Fjords region, and upper Cook Inlet (Figure 3). ${ }^{14} \mathrm{C}$ determinations from organics deposited shortly before the earthquake in these areas (Combellick 1991, 1993; 1994; Combellick and Reger 1994; Hamilton and Shennan 2005a,b) suggest that the 1964 great earthquake was preceded by similar events occurring approximately 800, 1400, 2200-2300, 3200, and 3600-3700 yr ago. There is also ambiguous evidence for a great earthquake about $1900 \mathrm{yr}$ ago, and a series of 3 closely spaced events between 2500-2850 yr ago.

It is less certain, however, that this chronology is applicable in areas further to the west. This is due, in part, to the paucity and low caliber of the geological evidence in some of these areas. For example, the eastern shore of central and lower Cook Inlet subsided by about $0.5 \mathrm{~m}$ in 1964 (Plafker 1969), and the geological imprint of previous coseismic land-level changes should therefore be visible in the tidal marshes of the deltas of the Kenai, Kasilof, and Fox rivers. But evidence of small land-level changes in high-energy deltas can be readily removed or overprinted by riverine floods and channel avulsions, and these tidal marshes exhibit complex depositional sequences as a result of interactions between these processes (Combellick 1994; Combellick and Reger 1994). The patchy geological evidence from these deltas means that the history of great earthquakes in this area is less well known than in areas further east. Although the great earthquakes at $\sim 1400 \mathrm{cal} \mathrm{BP}$ and 2700 $2800 \mathrm{cal} \mathrm{BP}$ seem to be registered in the stratigraphic archives at the Kenai delta, neither the $800 \mathrm{cal}$ BP nor the 2200-2300 cal BP events are strongly recorded there.

In the Kodiak Archipelago, geological evidence of coseismic subsidence at about 500 cal BP appears to be fairly widespread (Figure 3). An intervening event appears in the record on Kodiak Island, at approximately $1000 \mathrm{cal}$ BP. In these western reaches of the Alaskan subduction zone, however, the geological record is limited to the last 1500-1600 yr, and the incidence of prior great earthquakes cannot be determined.

\section{Archaeological Evidence of Great Earthquakes}

As acknowledged earlier, an exodus or local population decline that might give rise to a reduction in the site activity index may be triggered by factors other than tectonic forcings. Climate change, volcanism, disease, warfare, and ecological collapse can all have deleterious impacts on human populations and settlements. In southern Alaska, we have independent evidence of the functioning of only 1 of these alternative potential causes: climate change.

Patterns of Late Holocene climate change in southern Alaska have been reconstructed from several proxies for paleotemperature, such as pollen accumulation (Heusser et al. 1985), glacier margin fluctuations (Calkin et al. 2001), and lake geochemistry (Hu et al. 2001). These proxies suggest that there have been 3 periods of climatic deterioration in the Gulf of Alaska region in the last $4000 \mathrm{yr}$ (Figure 7c). It is likely that camps near fjord heads were abandoned during each of these phases as glaciers advanced. 
Unfortunately, the phases of glacial advance and retreat in southern Alaska often display local variations and are not tightly dated. The fluctuations in Late Holocene climate reconstructed by Heusser et al. (1985), Calkin et al. (2001), and Hu et al. (2001) are in broad agreement, but may be out of phase by several centuries, so the potential effects of climatic variation on site habitability are difficult to determine. What is apparent, however, from a comparison of the common parts of the archaeological and palaeotemperature records in Figure 7, is that "activity" at coastal village sites was controlled in part by the direct and indirect effects of Holocene climate change in the Gulf of Alaska. For example, the apparent reduction in site activity in the KOKA segment, and the apparently sparse occupation in the KEN and PWS segments in the interval from $\sim 3500$ to 2300 cal BP may be correlated with climatic deterioration during a neoglacial episode ("NG2"; Figure 7c). A more recent climatic deterioration ("NG1"; Figure 7c) appears to have had less extreme consequences.

While we recognize that non-tectonic processes undoubtedly influenced the populations of coastal villages, we suggest that correlative short-term changes in archaeological site activity may mark the catastrophic effects of plate-boundary earthquakes.

The penultimate great earthquake at the eastern end of the subduction zone, which occurred about $800 \mathrm{yr}$ ago, apparently led to the widespread destruction and abandonment of settlements as far west as Kachemak Bay. Some archaeological sites in the KOKA segment show evidence of a hiatus about 1 or 2 centuries later. Sand and gravel layers in middens on either side of Shelikof Strait were likely emplaced by the tsunamis that accompanied this later event. We tentatively conclude that the KOKA segment ruptured independently of the PWS and KEN segments $\sim 650 \mathrm{yr}$ ago. A younger event, at $\sim 500$ cal BP (Gilpin 1995), lies too close to the prehistoric/protohistoric threshold to be resolved by our analysis.

Sites on the outer coast of the PWS segment record a downturn associated with an inferred plateboundary earthquake at, or shortly after, $1400 \mathrm{cal} \mathrm{BP} \mathrm{(Figure} \mathrm{7).} \mathrm{Although} \mathrm{there} \mathrm{is} \mathrm{evidence} \mathrm{of} \mathrm{a} \mathrm{hia-}$ tus in occupation at the McArthur Pass site at about that time, there are too few dated sites on the outer coast of the KEN segment to resolve the effects of the earthquake in this area, and although the sites in Kachemak Bay show a downturn in activity at that time, the change is gradual and may not have been triggered by a great earthquake. Sites in the inner reaches of Prince William Sound show a dramatic increase in activity at about that time, suggesting that this area may have been a haven for people displaced from the outer coast. There is little evidence of disruption in the archaeological record at sites in the KOKA segment at that time, suggesting that this earthquake, like the one at $\sim 800 \mathrm{cal} \mathrm{BP}$, was limited to the KEN and PWS segments. The KOKA segment of the plate interface apparently slipped some 100-200 yr later. This event is not strongly recorded in the KOKA site activity index (Figure 7), but is reflected in midden stratigraphy, particularly at sites on the southern shore of Afognak Island.

A marked downturn in the site activity index in the KOKA segment after 1900 cal BP (Figure 7) may signal the next great earthquake in the sequence. Buried soils dating from about or shortly after 1900 yr ago are present at some sites in Turnagain Arm (Figure 3), but no correlative uplift episode is known from the Copper River delta. Minor downturns in the site activity indices in KEN and the outer coast sites in PWS may be a product of this event.

Possible tsunami deposits at an outer coast site in PWS may record the great earthquake at the eastern end of the subduction zone at $\sim 2200-2300 \mathrm{cal} \mathrm{BP}$, but the ${ }^{14} \mathrm{C}$ record prior to $2000 \mathrm{yr}$ ago is too meager to allow the activity pattern at these sites to be reconstructed with any certainty. The dramatic downturn in the site activity index in Kachemak Bay (Figure 7) implies that the 2200-2300 cal BP event may have had a severe impact on villages in this area. The site activity index from the 
KOKA segment also shows a slight downturn at this time (Figure 7), implying either that the earthquake propagated this far west, or that some sites were affected by tsunamis generated by this event. A further downturn in the index in the KOKA site activity index at 2400 cal BP may represent the effects of an earthquake restricted to this segment.

A region-wide downturn in the site activity index from the KOKA and KEN segments $~ 2600-2700$ yr ago (Figure 7) may well represent the after-effects of the first or second of the 3 potential subsidence episodes recorded at about this time by buried soils in Turnagain Arm and Kenai River delta. This event is likely contemporaneous with an episode of uplift at Copper River delta represented by the younger group of AMS ages associated with event IV in the Plafker and Rubin (1994) chronology (Figure 3).

The episode of uplift at Copper River delta represented by the older AMS age associated with event IV in the Plafker and Rubin (1994) chronology, and by buried soils in Turnagain Arm (Figure 3), is matched by a downturn in the activity index at sites on the outer coasts of the KOKA segment (Figure 7), suggesting that a rupture $\sim 3200 \mathrm{yr}$ ago may have propagated as far west as Kodiak Archipelago.

On the basis of the archaeological evidence, we propose that at least 3 of the prehistoric great earthquakes recorded in the stratigraphic archives at the eastern end of the Alaska subduction zone may have ruptured the entire Alaska plate boundary, and were therefore likely equivalent in magnitude to the 1964 earthquake. These events occurred approximately 2200-2300, 2600-2700, and 3100$3200 \mathrm{yr}$ ago. Two great earthquakes (at $\sim 800 \mathrm{cal}$ BP and, with less certainty, the event at $\sim 1400 \mathrm{cal}$ BP) appear to have been restricted to the KEN and PWS segments. Several great earthquakes (e.g. at $\sim 600-700 \mathrm{cal} \mathrm{BP}$ ) appear to have been restricted to the KOKA segment, and the rupture area of the inferred great earthquakes at $\sim 1900 \mathrm{cal} \mathrm{BP}$ and $3600-3700 \mathrm{cal}$ BP remains undetermined.

It is apparent from this discussion that, although there are still local ambiguities and discrepancies that need to be resolved at the eastern end of the Alaska subduction zone, the great earthquake chronology derived from episodes of abrupt uplift at the Copper River delta is generally applicable as far west as the Kenai Peninsula. This suggests that the PWS and KEN segments generally behave as a coherent unit of the Alaska megathrust. Geological evidence and ancillary archaeological data indicate that the KOKA segment is characterized by semi-independent behavior, and at least 2 , and perhaps as many as 4 of the last 7 prehistoric great earthquakes at this plate boundary did not propagate this far west. In addition, this area may generate large or great earthquakes independently of areas further east-perhaps in concert with adjacent segments of the Aleutian subduction zone. If these inferences are correct, then the behavior of the Alaska subduction zone is more complex than is generally recognized, and this should be accommodated in seismic hazard assessments for the area.

\section{ACKNOWLEDGMENTS}

We thank Deirdre Dobson and Rita Eagle for research assistance, and Ben Fitzhugh for sharing field notes and experience. Patrick Saltonstall kindly allowed us to reproduce a photograph of the Settlement Point site. This paper was considerably improved by comments by an anonymous reviewer. We gratefully acknowledge funding from the National Earthquake Hazard Reduction Program of the US Geological Survey (01-HQ-GR-0022). 


\section{REFERENCES}

Bartsch-Winkler S, Schmoll HR. 1992. Utility of radiocarbon-dated stratigraphy in dating late Holocene earthquake recurrence intervals, upper Cook Inlet region, Alaska. Geological Society of America Bulletin 104(6):684-94.

Biasi G, Weldon II RJ. 2003. Parametric investigation of paleoseismic event correlation, with application to the southern San Andreas Fault. Poster presented at the Annual Meeting of the Seismological Society of America, San Juan, Puerto Rico, May 2003.

Brocher TM, Fuis GS, Fisher MA, Plafker G, Moses MJ, Taber JJ, Christensen NI. 1994. Mapping the megathrust beneath the northern Gulf of Alaska using wideangle seismic data. Journal of Geophysical Research 99(B6): 11,663-86.

Calkin PE, Wiles GC, Barclay DJ. 2001. Holocene coastal glaciation of Alaska. Quaternary Science Reviews 20(1-3):449-61.

Christensen DH, Beck SL. 1994. The rupture process and tectonic implications of the great 1964 Prince William Sound earthquake. Pure and Applied Geophysics 142(1):29-53.

Chaney G. 1997. Observations concerning Holocene tectonism and associated shoreline changes in Prince William Sound, Alaska. In: Yarborough LF, editor. Exxon Valdez Oil Spill Restoration Project, final report: site-specific archaeological restoration at SEW440 and SEW-488. Restoration project 95007B. Appendix B. p 137-69.

Combellick RA. 1991. Paleoseismicity of the Cook Inlet region, Alaska: evidence from peat stratigraphy in Turnagain and Knik Arms. Short Notes on Alaskan Geology 1993. State of Alaska, Department of Natural Resources, Division of Geological and Geophysical Surveys, Professional Report No. 112. 56 p.

Combellick RA. 1993. The penultimate great earthquake in south-central Alaska: evidence from a buried forest near Girdwood. Short Notes on Alaskan Geology 1993. State of Alaska, Department of Natural Resources, Division of Geological and Geophysical Surveys, Professional Report No. 113. p 7-15.

Combellick RA. 1994. Investigation of peat stratigraphy in tidal marshes along Cook Inlet, Alaska, to determine the frequency of 1964-style great earthquakes in the Anchorage region. Report of Investigations 94-7. State of Alaska, Department of Natural Resources, Division of Geological and Geophysical Surveys.

Combellick RA, Reger RD. 1994. Sedimentological and radiocarbon-age data for tidal marshes along eastern and upper Cook Inlet, Alaska. State of Alaska, Department of Natural Resources, Division of Geological and Geophysical Surveys, Report of Investigations 94-6. $60 \mathrm{p}$.

Crocker RL, Major J. 1955. Soil development in relation to vegetation and surface age at Glacier Bay, Alaska. Journal of Ecology 43:427-48.
Crowell AL. 2000. Maritime cultures of the Gulf of Alaska. Revista Arqueología Americana 19:178-216.

Crowell AL, Mann DH. 1996. Human populations, sealevel change, and the archaeological record of the northern Gulf of Alaska coastline. Arctic Anthropology 33(2):16-37.

Crowell AL, Mann DH. 1998. Archaeology and coastal dynamics of Kenai Fjords National Park, Gulf of Alaska. Anchorage: US National Park Service.

Crowell AL, Moore M, Mann DH. 2003. Subsistence resources and archaeological settlement patterns on the Katmai coast. Alaska Journal of Anthropology 1(2): 62-96.

Davies J, Sykes L, House L, Jacob K. 1981. Shumagin seismic gap, Alaska Peninsula; history of great earthquakes, tectonic setting, and evidence for high seismic potential. Journal of Geophysical Research 86(B5): 3821-55.

de Laguna F. 1956. Chugach Prehistory: The Archaeology of Prince William Sound, Alaska. University of Washington Publications in Anthropology, Volume 13. Seattle: University of Washington Press. 289 p.

de Laguna F. 1975. The Archaeology of Cook Inlet, Alaska. 2nd edition. Anchorage: Alaska Historical Society. 264 p.

Dekin Jr AA, Cassell MS, Ebert JI, Camilli E, Kerley JM, Yarborough MR, Stahl PA, Trucy BL. 1993. Exxon Valdez Oil Spill Archaeological Damage Assessment, final report. The Research Foundation of the State University of New York, Binghamton.

Doser DI, Ratchovski NA, Haeussler PJ, Saltus R. 2004. Changes in crustal seismic deformation rates associated with the 1964 Great Alaska earthquake. Bulletin of the Seismological Society of America 94(1):320-5.

Erlandson J, Crowell A, Wooley C, Haggarty J. 1992. Spatial and temporal patterns in Alutiiq paleodemography. Arctic Anthropology 29(2):42-62.

Estabrook CH, Jacob KH, Sykes LR. 1994. Body wave and surface wave analysis of large and great earthquakes along the eastern Aleutian arc, 1923-1993: implications for future events. Journal of Geophysical Research 99(B6): 11,643-62.

Ferris A, Abers GA, Christensen DH, Veenstra E. 2003. High resolution image of the subducted Pacific (?) plate beneath central Alaska, $50-150 \mathrm{~km}$ depth. Earth and Planetary Science Letters 214(3-4):575-88.

Freymueller JT, Cohen SC, Fletcher HJ. 2000. Spatial variations in present-day deformation, Kenai Peninsula, Alaska, and their implications. Journal of Geophysical Research 105(B4):8079-102.

Gilpin LM. 1995. Holocene paleoseismicity and coastal tectonics of the Kodiak Islands, Alaska [PhD dissertation]. University of California, Santa Cruz. 358 p.

Goff JR, McFadgen BG. 2001. Catastrophic seismic-related events and their impact on prehistoric human occupation, coastal New Zealand. Antiquity 75(287): 
$155-62$.

Griscom A, Sauer PE. 1990. Interpretation of magnetic maps of the northern Gulf of Alaska, with emphasis on the source of the slope anomaly. US Geological Survey Open-File Report 90-348. 18 p.

Haggarty JC, Wooley CB, Erlandson JM, Crowell A. 1991. The 1990 Exxon Cultural Resource Program: site protection and maritime cultural ecology in Prince William Sound and the Gulf of Alaska. Anchorage: Exxon Shipping Company and Exxon Company.

Hamilton S, Shennan I. 2005a. Late Holocene relative sea-level changes and the earthquake deformation cycle around upper Cook Inlet, Alaska. Quaternary Science Reviews 24(12-13):1479-98.

Hamilton S, Shennan I. 2005b. Late Holocene great earthquakes and relative sea-level change at Kenai, southern Alaska. Journal of Quaternary Science 20(2):95-111.

Hamilton SL, Shennan I, Combellick R, Mulholland J, Noble C. 2005. Evidence for two great earthquakes at Anchorage, Alaska and implications for multiple great earthquakes through the Holocene. Quaternary Science Reviews 24(18-19):2050-68.

Heusser CJ, Heusser LE, Peteet DM. 1985. Late-Quaternary climatic change on the American North Pacific coast. Nature 315(6019):485-7.

Hu FS, Ito E, Brown TA, Curry BB, Engstrom DR. 2001. Pronounced climatic variations in Alaska during the last two millennia. Proceedings of the National Academy of Sciences (USA) 98(19):10,552-6.

Hutchinson I, Crowell AL. 2006. Great earthquakes and tsunamis at the Alaska subduction zone: geoarchaeological evidence of recurrence and extent. NEHRP Grant 01-HQ-GR-0022 final report. United States Geological Survey.

Hutchinson I, McMillan AD. 1997. Archaeological evidence for village abandonment associated with late Holocene earthquakes at the northern Cascadia subduction zone. Quaternary Research 48(1):79-87.

Johnson JM, Satake K, Holdahl SR, Sauber J. 1996. The 1964 Prince William Sound earthquake: joint inversion of tsunami and geodetic data. Journal of Geophysical Research 101(B1):523-32.

Jordan RH, Knecht RA. 1988. Archaeological research on western Kodiak Island, Alaska: the development of Koniag culture. In: Shaw RD, Harritt RK, Dumond DE, editors. The Late Prehistoric Development of Alaska's Native People. Anchorage: Alaska Anthropological Association Monograph No. 4. p 225-306.

Kanamori H. 1977. The energy release in great earthquakes. Journal of Geophysical Research 82(20): 2981-7.

Kay S, Kay RW, Citron GP. 1982. Tectonic controls on tholeitic and calc-alkaline magmatism in the Aleutian arc. Journal of Geophysical Research 87(B5):405172.

Kienle J, Swanson SE. 1983. Volcanism in the eastern
Aleutian arc: late Quaternary and Holocene centers, tectonic setting and petrology. Journal of Volcanology and Geothermal Research 17(1-4):393-432.

Knecht RA. 1995. The late prehistory of the Alutiiq people: culture change on the Kodiak Archipelago from AD 1200-1750 [PhD dissertation]. Bryn Mawr: Bryn Mawr College.

Lander JF. 1996. Tsunamis affecting Alaska 1737-1996. NGDC key to geophysical research documentation No. 31. National Geophysical Data Center, Boulder, Colorado 80303-3328, USA.

Mann DH, Crowell AL. 1996. A large earthquake occurring 700-800 years ago in Aialik Bay, southern coastal Alaska. Canadian Journal of Earth Sciences 33(1): 117-26.

Marsh BD. 1979. Island arc development; some observations, experiments, and speculations. Journal of Geology 87:687-714.

Maschner HDG. 1995. A comment on the Kachemak to Koniag transition on Kodiak Island. Paper presented at the 22nd Annual Meeting of the Alaska Anthropological Association, Anchorage.

Maschner HDG. 1999. Prologue to the prehistory of the Alaska Peninsula. Arctic Anthropology 36:84-102.

Mason OK. 2006. Preliminary report on Bear Cove geoarchaeological research in 2004 [unpublished report]. Anchorage: Arctic Studies Center, National Museum of Natural History, Smithsonian Institution.

Mills RO. 1994. Radiocarbon calibration of archaeological dates from the central Gulf of Alaska. Arctic Anthropology 31:126-49.

Mobley CM, Haggarty JC, Utermohle CJ, Eldridge M, Reanier RE, Crowell A, Ream BA, Yesner DR, Erlandson JM, Buck PE. 1990. The 1989 Exxon Valdez Cultural Resource Program. Anchorage: Exxon Shipping Company and Exxon Company.

Nelson AR. 1992. Discordant ${ }^{14} \mathrm{C}$ ages from buried tidalmarsh soils in the Cascadia subduction zone, southern Oregon coast. Quaternary Research 38(1):74-90.

Plafker G. 1965. Tectonic deformation associated with the 1964 Alaska earthquake. Science 148(3678): 1675-87.

Plafker G. 1969. Tectonics of the March 27, 1964 Alaska earthquake. US Geological Survey, Professional Paper 543-I. 74 p.

Plafker G. 1990. Regional vertical tectonic displacement of shorelines in south-central Alaska during and between great earthquakes. Northwest Science 64(5): 250-8.

Plafker G, Kachadoorian R. 1966. Geologic effects of the March 1964 earthquake and associated seismic sea waves on Kodiak and nearby islands, Alaska. US Geological Survey, Professional Paper 543(D):D1-D46.

Plafker G, Rubin M. 1978. Uplift history and earthquake recurrence as deduced from marine terraces on Middleton Island, Alaska. In: Proceedings of Conference VI, "Methodology for Identifying Seismic Gaps and 
Soon-to-Break Gaps." US Geological Survey Open File Report 78-943. p 687-721.

Plafker G, Rubin M. 1994. Paleoseismic evidence for "Yo-Yo" tectonics above the eastern Aleutian subduction zone: coseismic uplift alternating with even larger interseismic subsidence. In: Proceedings of the Workshop on Paleoseismology. Marshall, California, 18-22 September 1994. p 155-7.

Plafker G, LaJoie KR, Rubin M. 1992. Determining recurrence intervals of great subduction zone earthquakes in southern Alaska by radiocarbon dating. In: Taylor RE, Long A, Kra RS, editors. Radiocarbon After Four Decades. New York: Springer-Verlag. p 43653.

Pulpan H, Frolich C. 1985. Geometry of the subducted plate near Kodiak Island and lower Cook Inlet, Alaska, determined from relocated earthquake hypocenters. Bulletin of the Seismological Society of America 75(3):791-810.

Ratchovski NA, Hansen RA. 2002. New evidence for segmentation of the Alaska subduction zone. Bulletin of the Seismological Society of America 92(5):175465.

Reger DR. 1987. Archaeology of a late prehistoric subsistence locality, the Clam gulch site (49KEN-O45). Anthropological Papers of the University of Alaska 21 (1/2):89-103.

Reger DR, Boraas A. 1996. An overview of the radiocarbon chronology in Cook Inlet prehistory. In: Davis NY, Davis WE, editors. Adventures Through Time: Readings in the Anthropology of Cook Inlet, Alaska. Anchorage: Cook Inlet Historical Society. p 155-71.

Reimnitz E. 1966. Late Quaternary history and sedimentation of the Copper River delta and vicinity [PhD dissertation]. University of California, San Diego. 160 p.

Richards SW. 2000. Holocene history of the Katalla River valley, Alaska [MSc thesis]. Salt Lake City: University of Utah. $130 \mathrm{p}$.

Saltonstall PG, Carver GA. 2002. Earthquakes, subsidence and prehistoric site attrition: a view from the Settlement Point site, Kodiak Archipelago, Alaska. In: Torrence R, Grattan J, editors. Natural Disasters, Catastrophism, and Cultural Change. New York: Routledge. p 172-92.

Soloviev SL. 1968. The Sanak-Kodiak tsunami of 1788.
In: The Tsunami Problem. Moscow: Nauka. p 232-7. Translated in Science of Tsunami Hazards (1990) 8: 34-8.

Stephens CD, Fogelman KA, Lahr JC, Page RA. 1984. Wrangell Benioff zone, southern Alaska. Geology 12(6):373-6.

Stuiver M, Reimer PJ. 1993. Extended ${ }^{14} \mathrm{C}$ data base and revised CALIB $3.0{ }^{14} \mathrm{C}$ age calibration program. $R a$ diocarbon 35(1):215-30.

Stuiver M, Reimer PJ, Bard E, Beck JW, Burr GS, Hughen KA, Kromer B, McCormac G, van der Plicht J, Spurk M. 1998. IntCal98 radiocarbon age calibration, 24,000-0 cal BP. Radiocarbon 40(3):1041-83.

Thilenius JF. 1990. Plant succession on earthquake uplifted coastal wetlands, Copper River delta, Alaska. Northwest Science 64(5):259-62.

Thilenius JF. 1995. Phytosociology and succession on earthquake-uplifted coastal wetlands, Copper River delta, Alaska. General technical report PNW-GTR346. Portland: USDA Forest Service; Pacific Northwest Research Station. 58 p.

van Wormer JD, Davies J, Gedney L. 1974. Seismicity and plate tectonics in south central Alaska. Bulletin of the Seismological Society of America 64(5):1467-75.

von Huene R, Klaeschen D, Fruehn J. 1999. Relation between subducting plate and seismicity associated with the great 1964 Alaska earthquake. Pure and Applied Geophysics 154(3-4):575-91.

Wesson RL, Frankel AD, Mueller CS, Harmsen SC. 1999. Probabilistic seismic hazard maps of Alaska. United States Geological Survey, Open-File Report 99-36. $20 \mathrm{p}$.

Winslow MA, Johnson LL. 1989. Prehistoric settlement patterns in a tectonically unstable environment: outer Shumagin Islands, southwestern Alaska. Geoarchaeology 4(4):297-318.

Yarborough LF. 1997. Exxon Valdez Oil Spill Restoration, final report. Site-specific archaeological restoration at SEW-440 and SEW-488; Restoration project 95007B. USDA, Chugach National Forest, Alaska. $228 \mathrm{p}$.

Yarborough MR, Yarborough LF. 1991. Uqciuvit: a multicomponent site in northwestern Prince William Sound, Alaska. Anchorage: USDA Forest Service. 


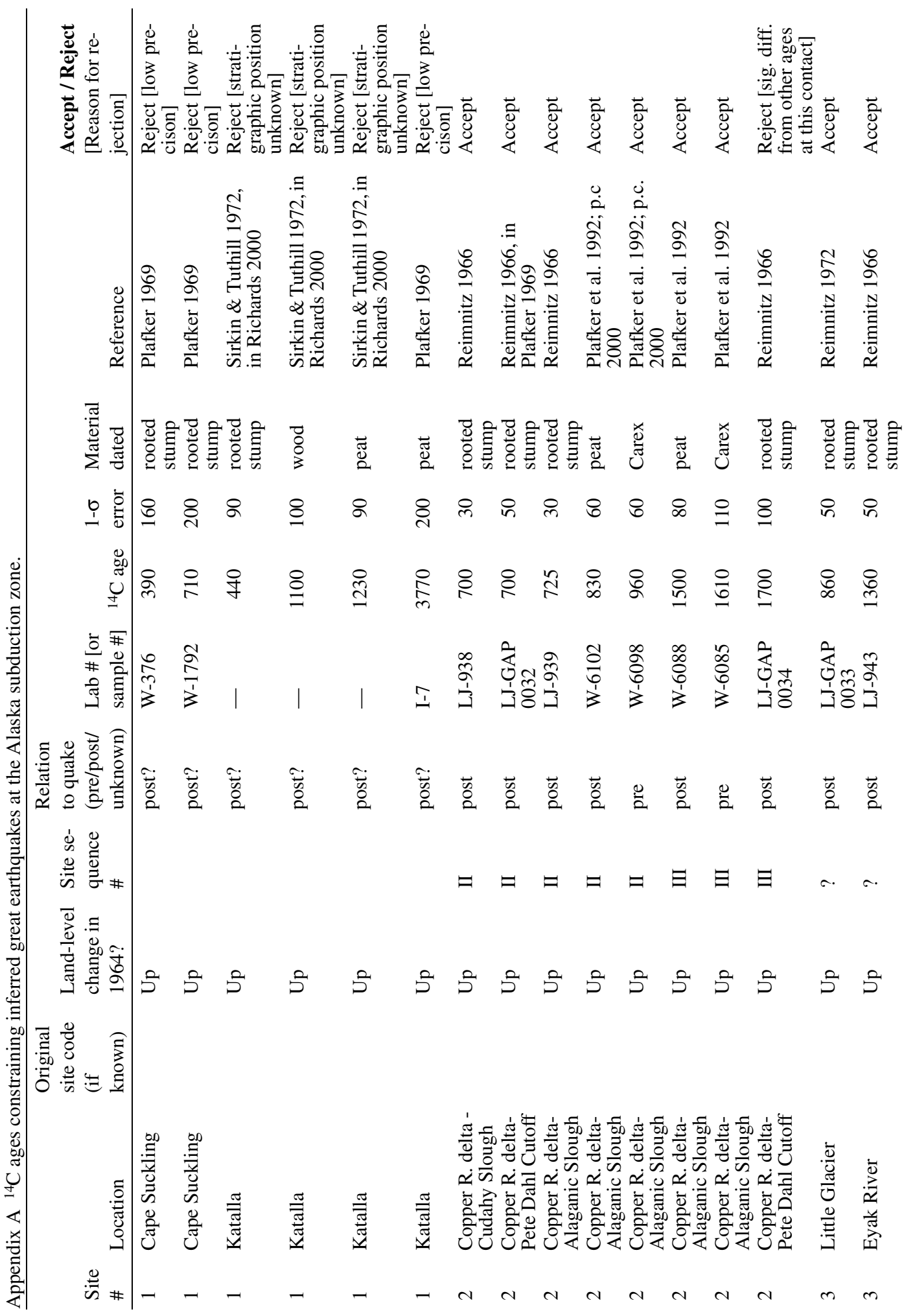




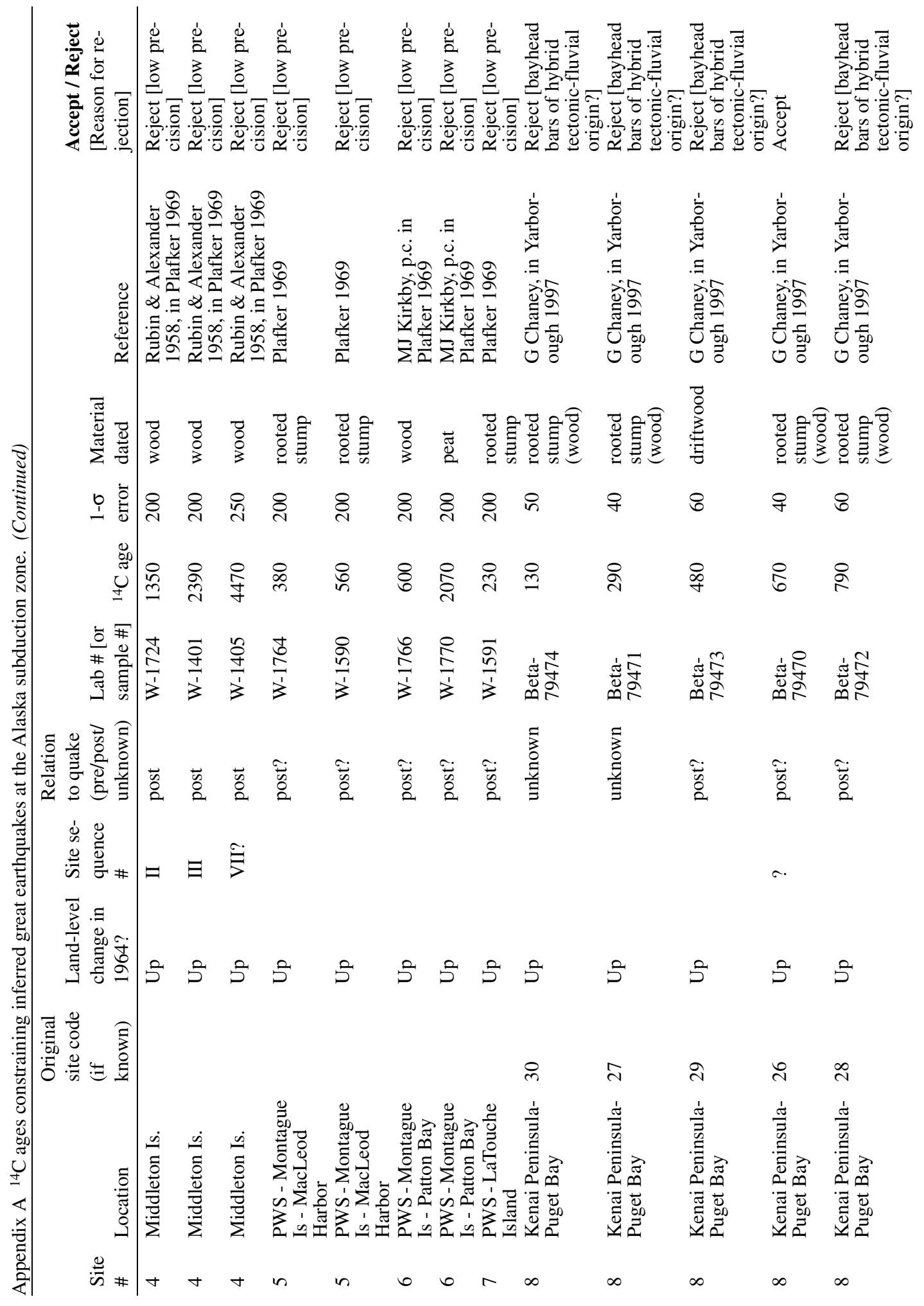









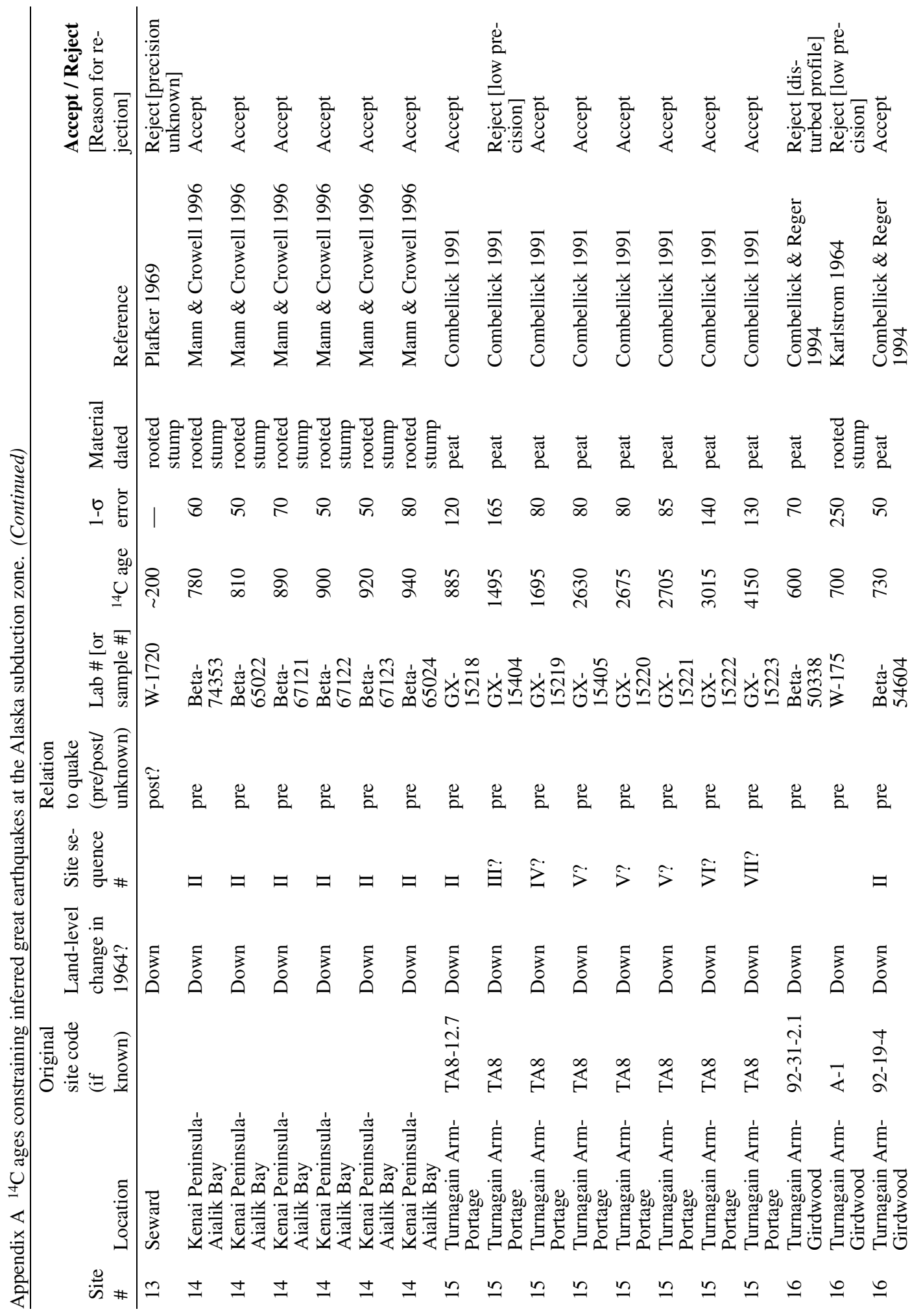




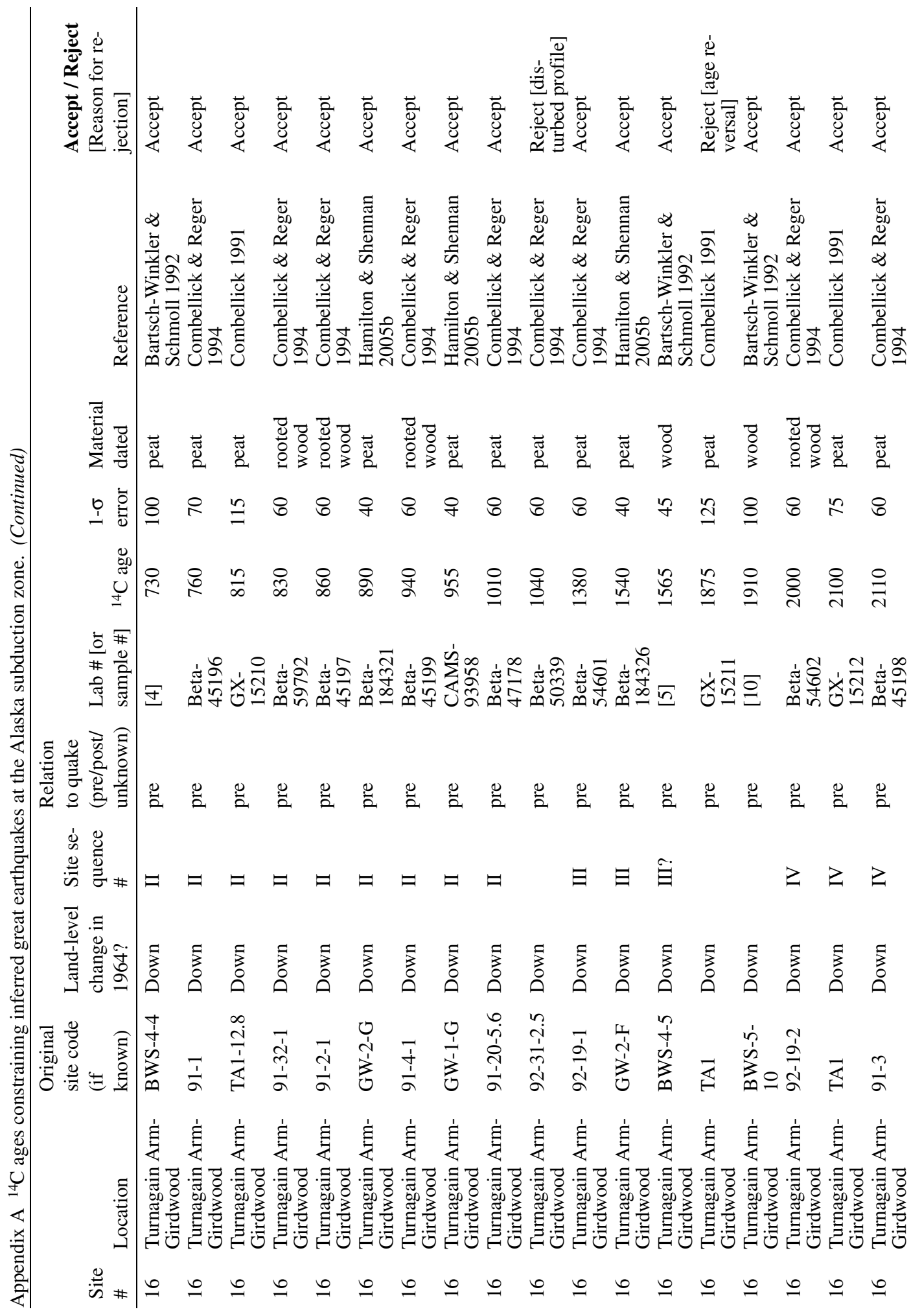




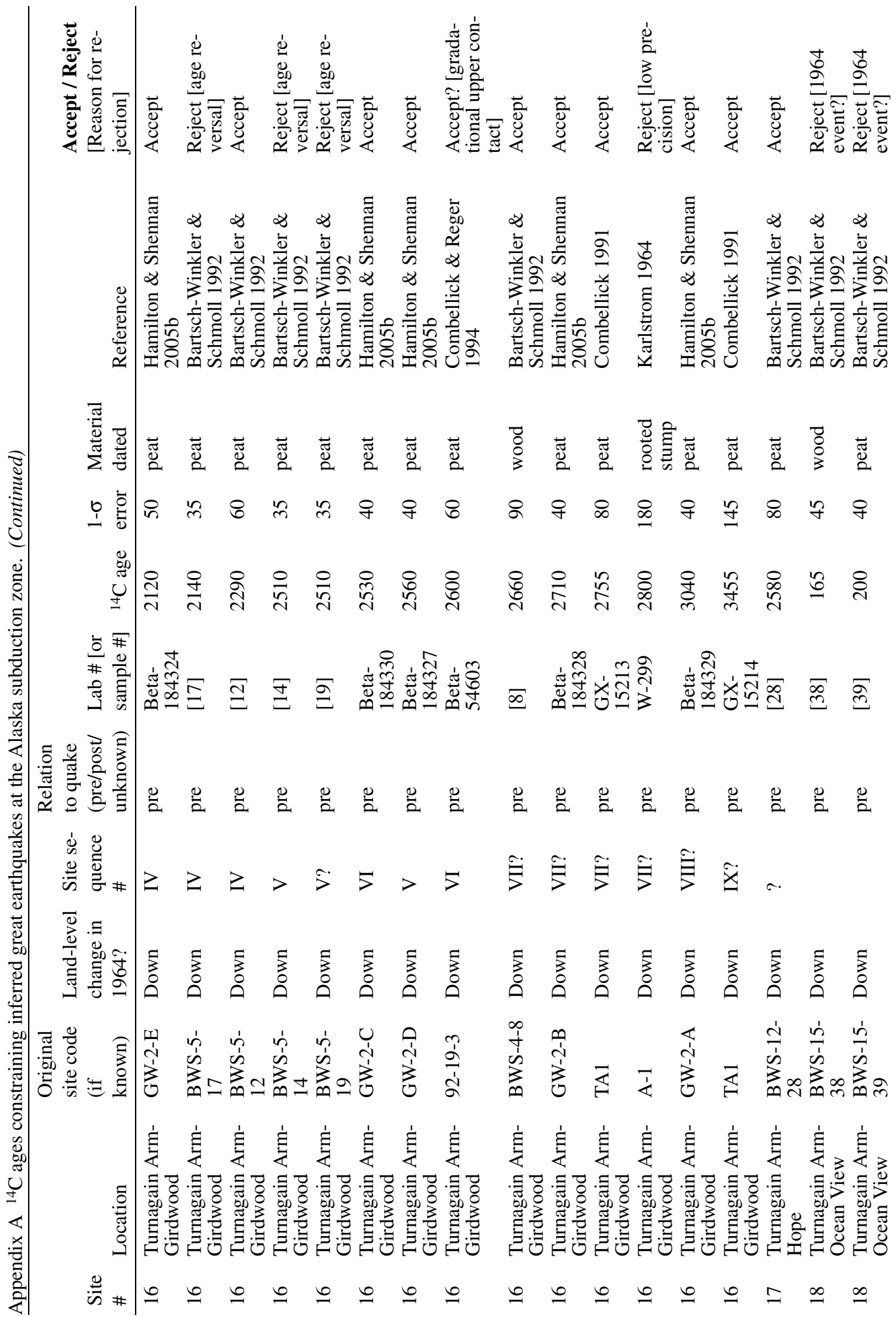




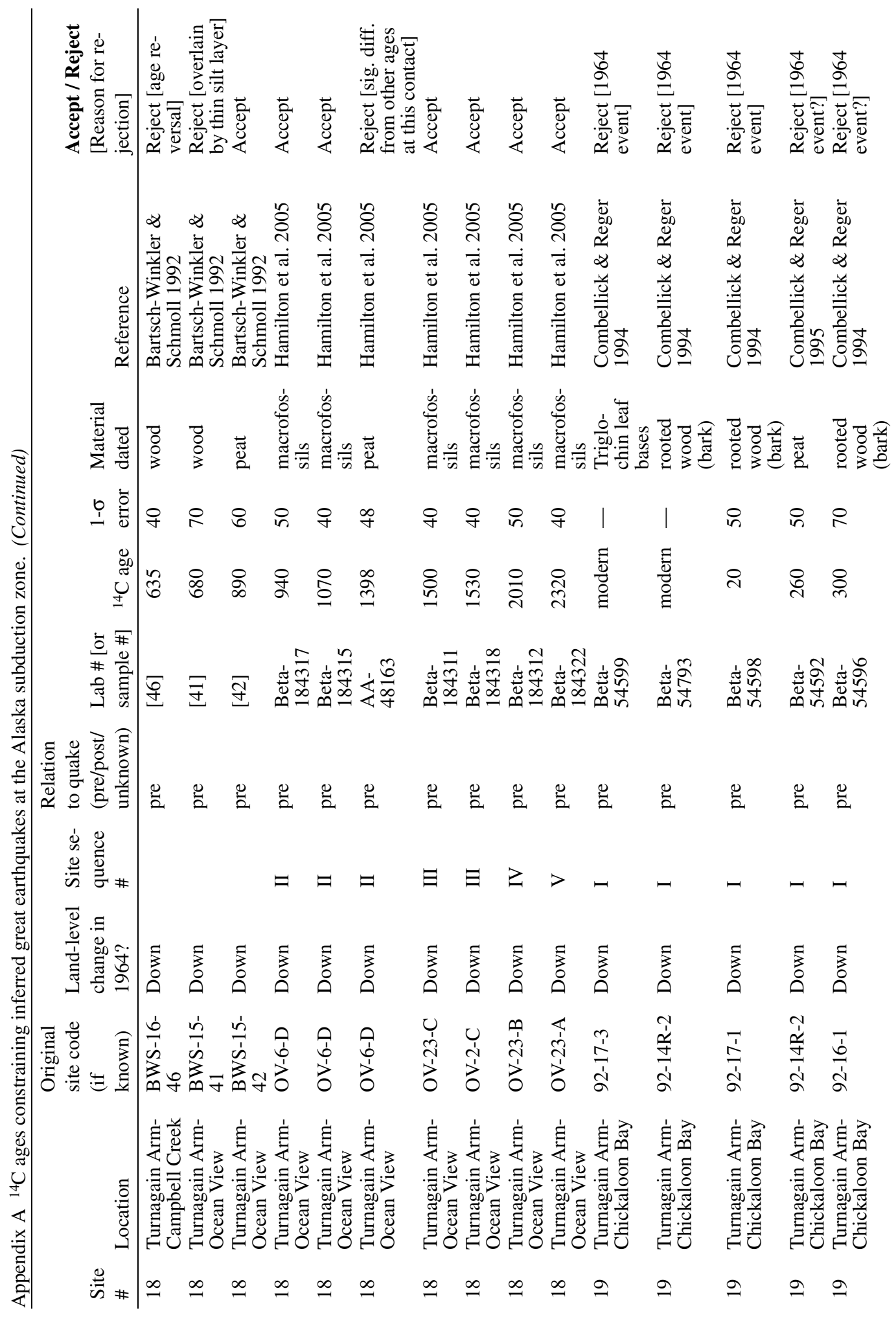


I Hutchinson \& A L Crowell

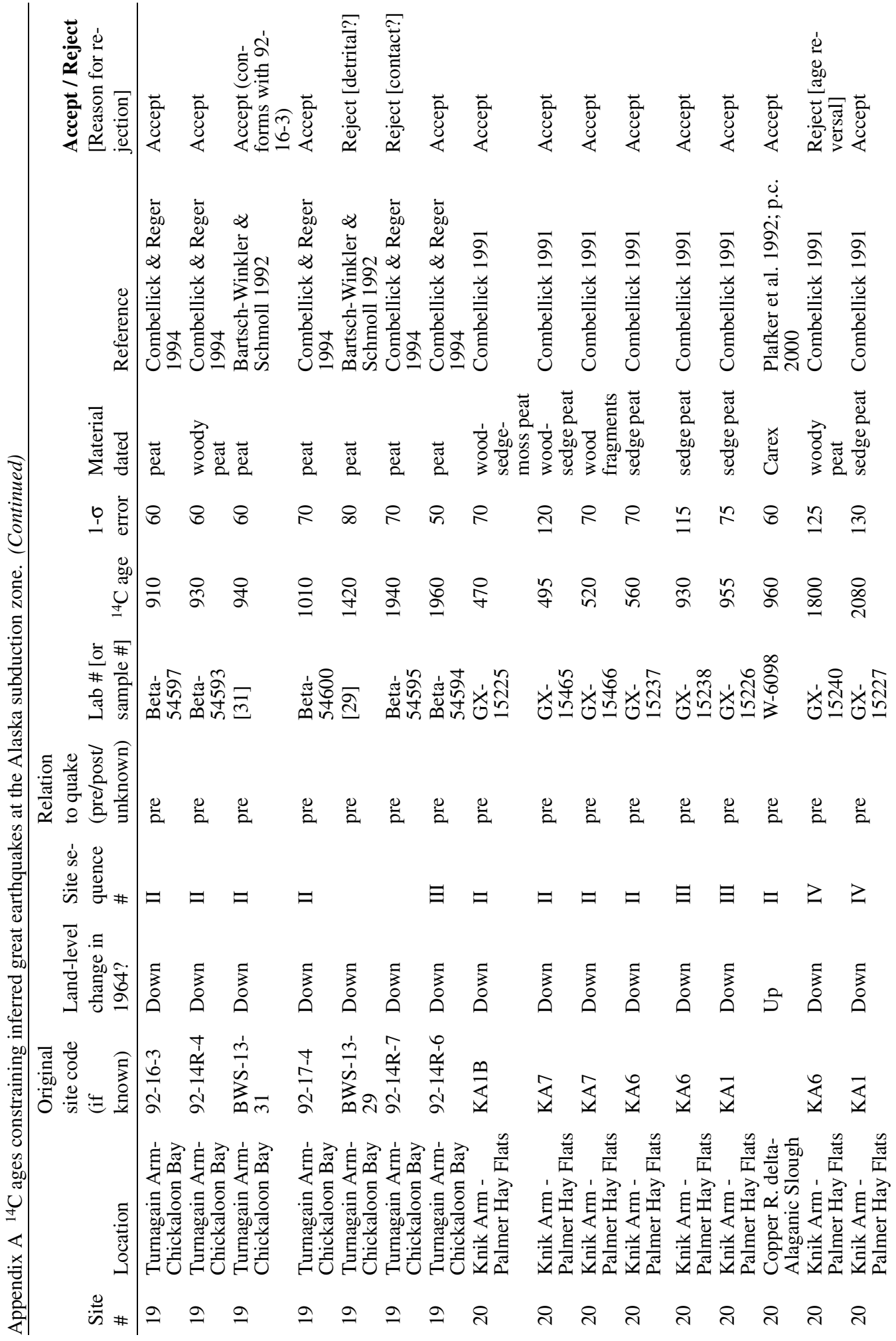




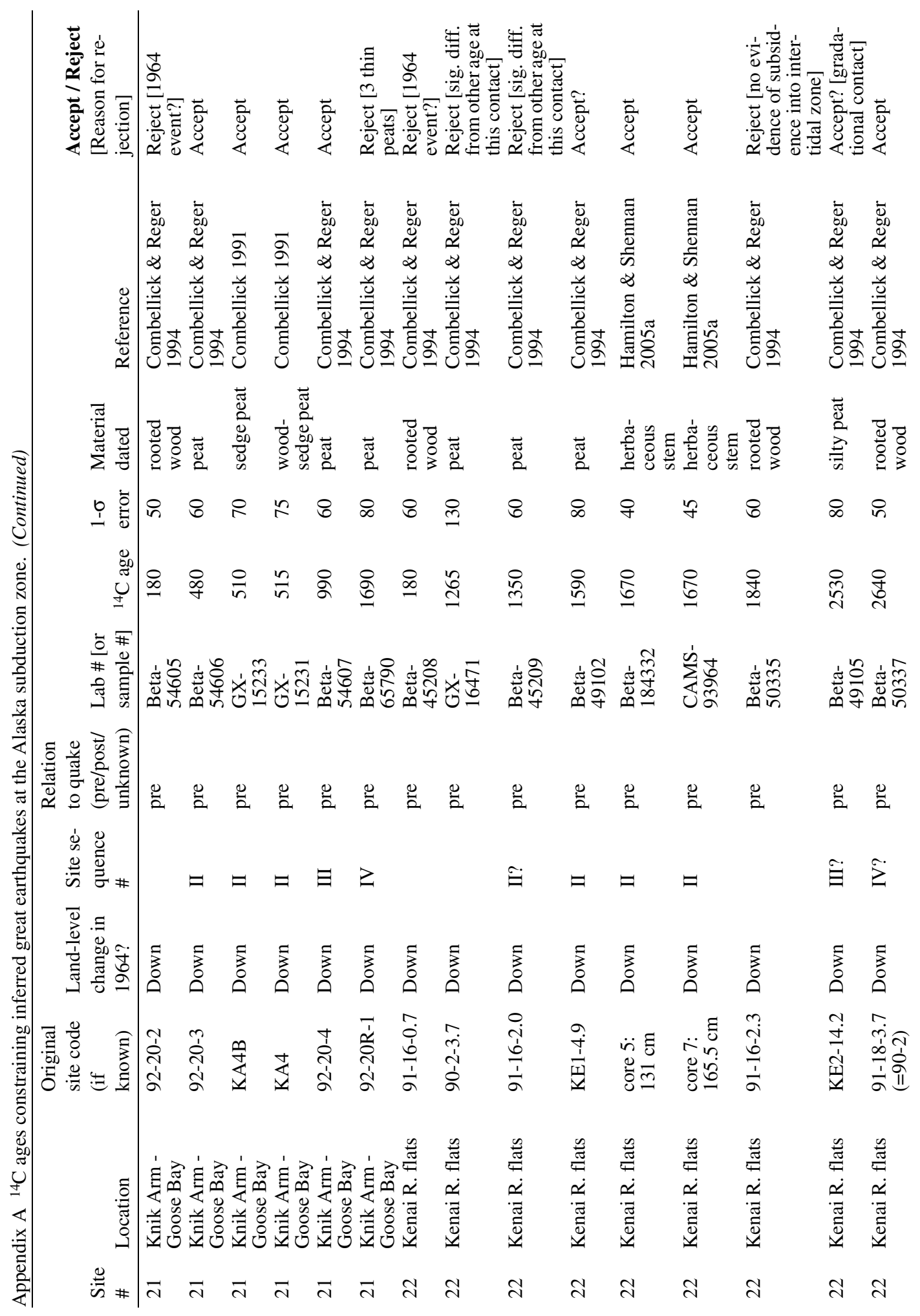




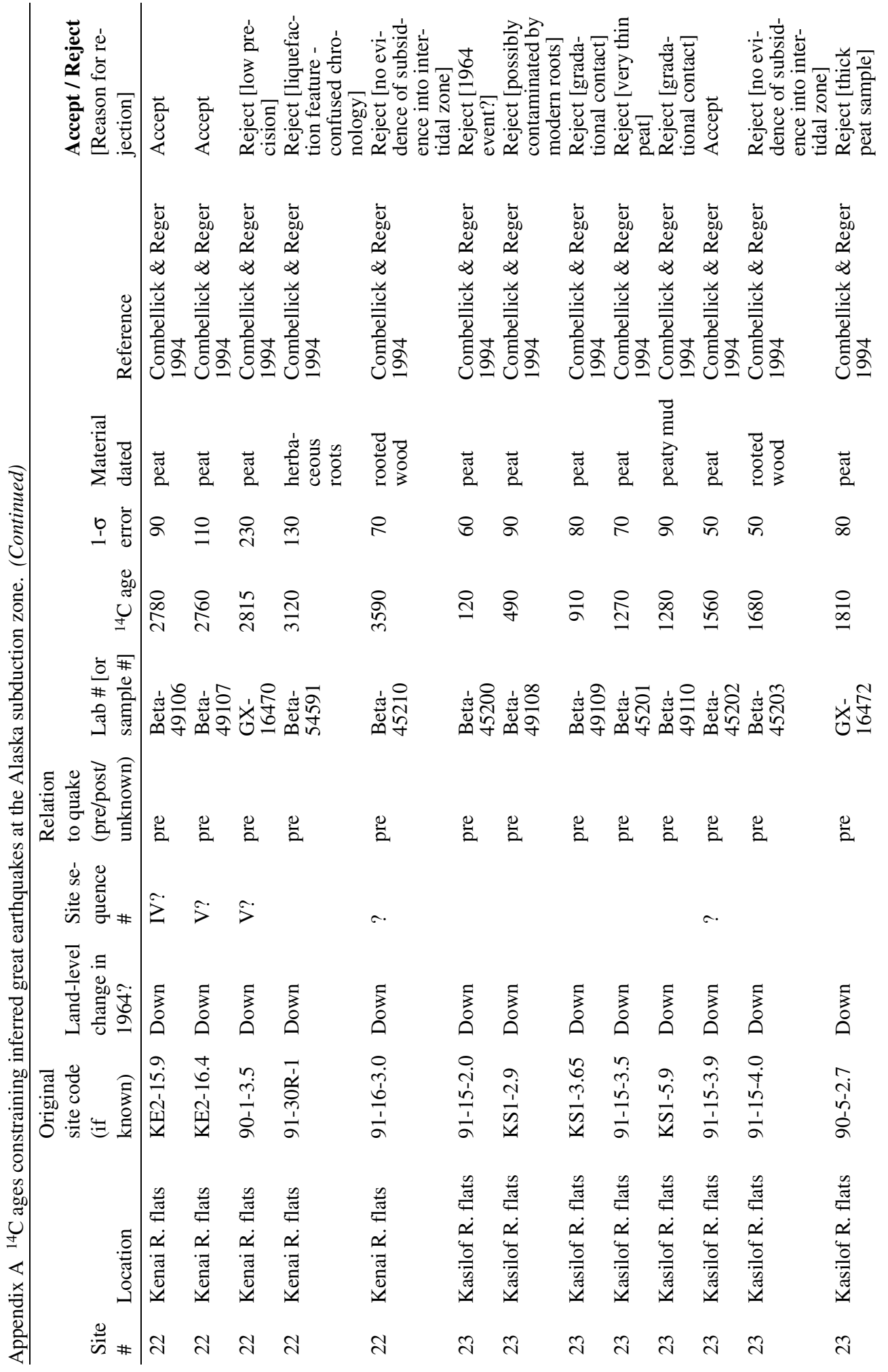









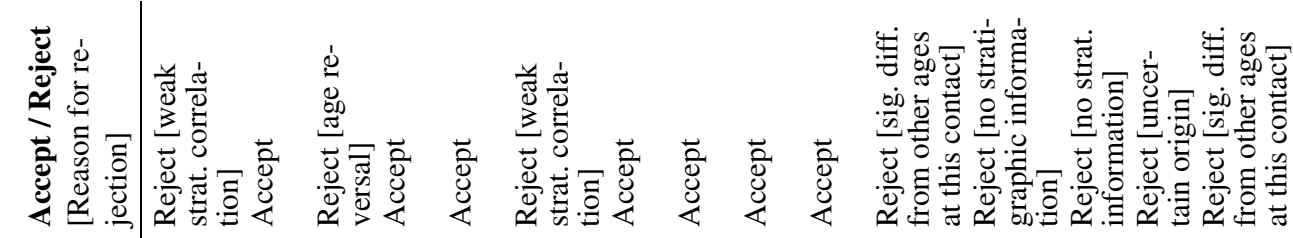

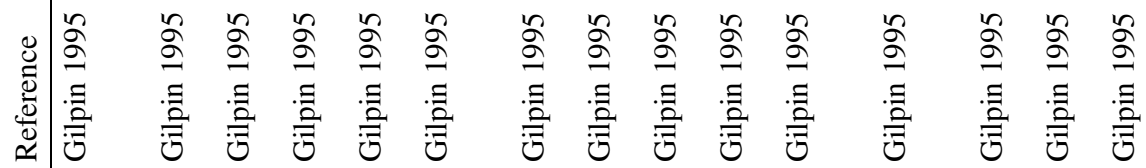



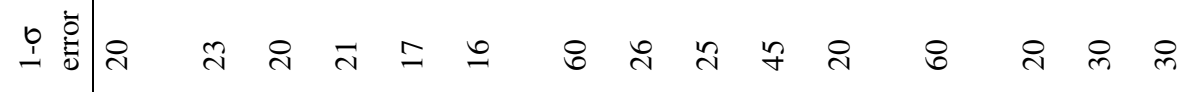

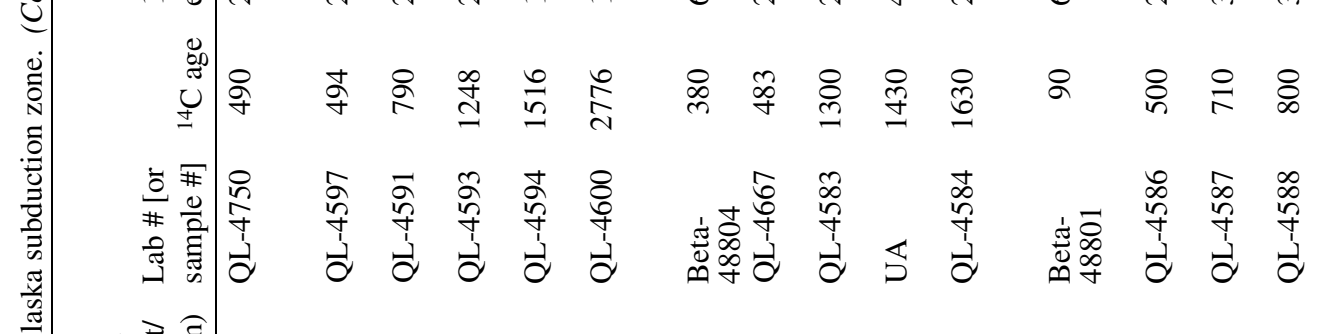

. 하을

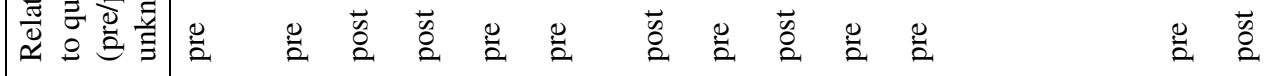

$\stackrel{0}{\stackrel{0}{*}}$

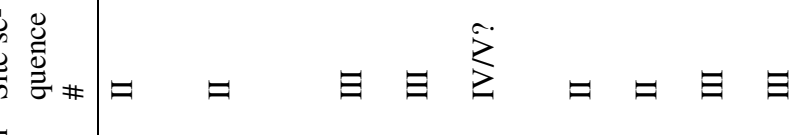

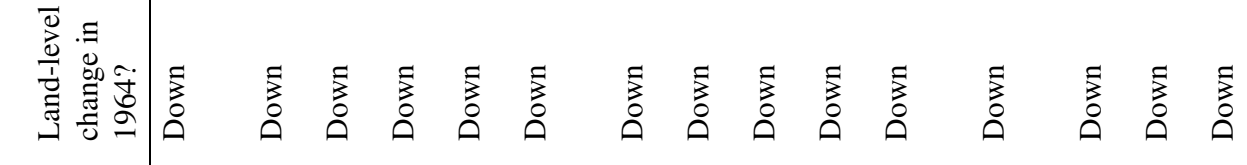

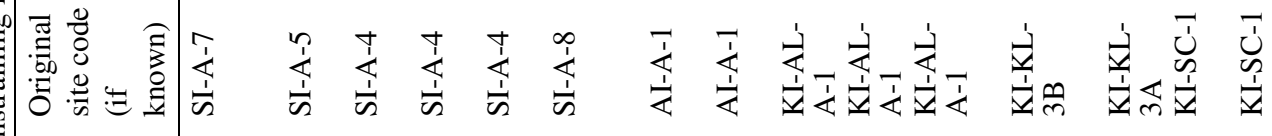

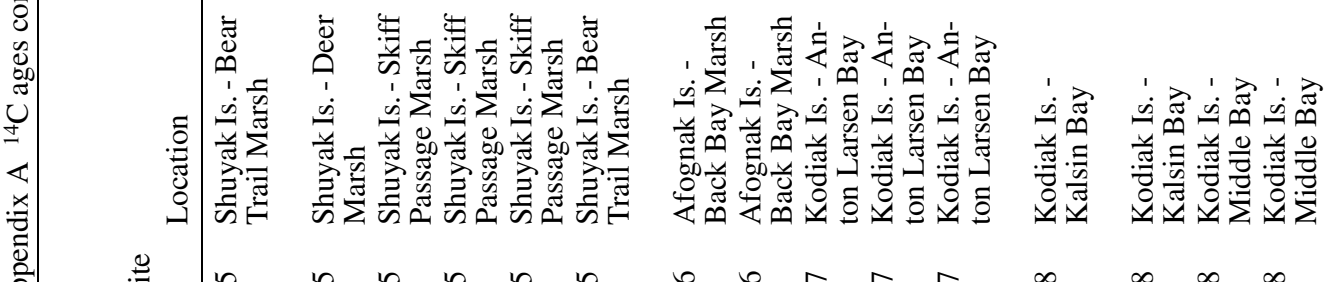

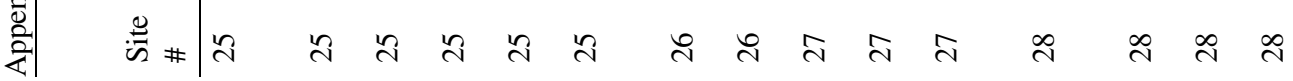




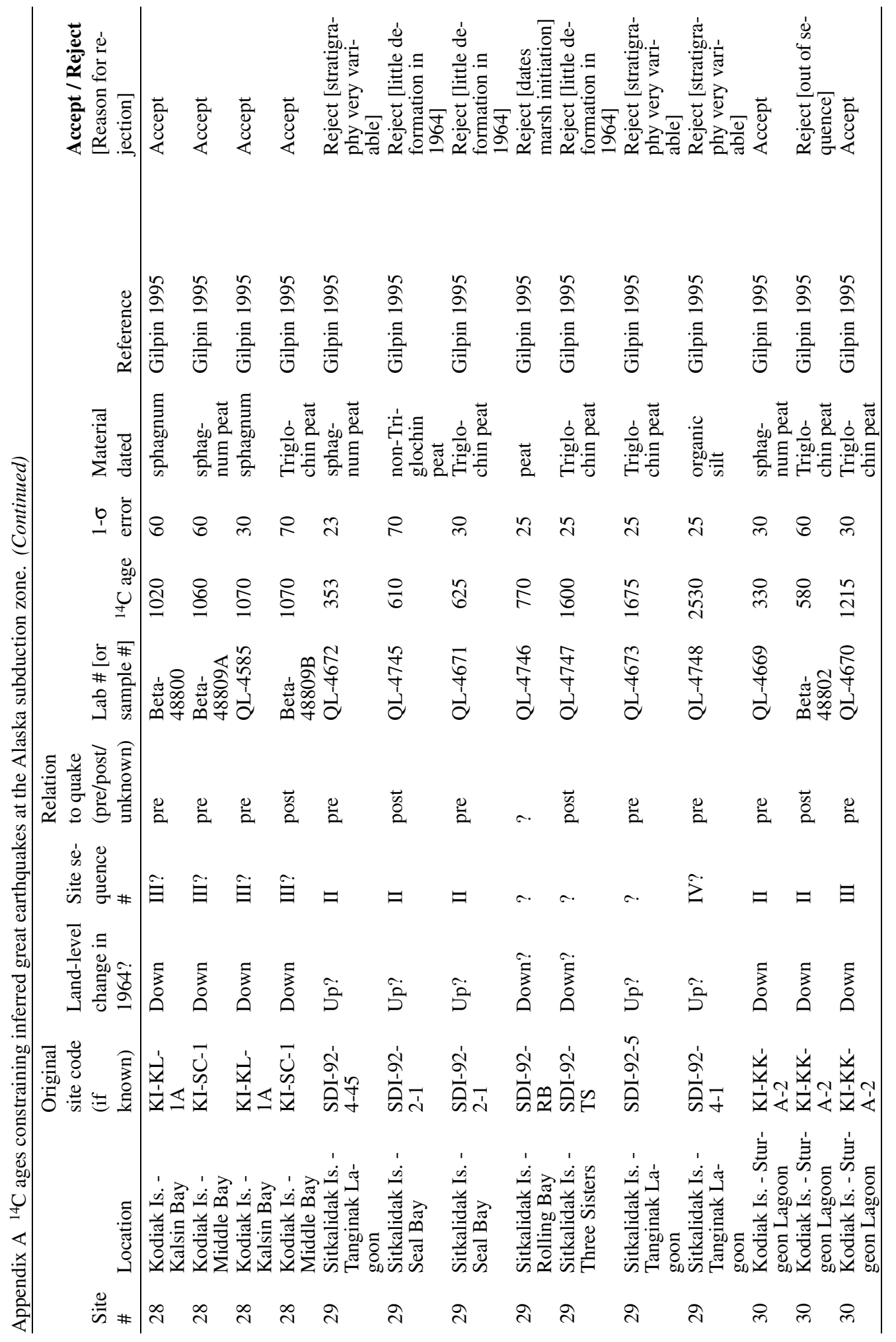


Appendix B Late Holocene ${ }^{14} \mathrm{C}$ ages from prehistoric coastal archaeological sites at the Alaska subduction zone.

\begin{tabular}{|c|c|c|c|c|c|c|c|}
\hline $\begin{array}{l}\text { AHRS nr } \\
(49-)\end{array}$ & Site name & Lab nr & $\begin{array}{l}{ }^{14} \mathrm{C} \\
\text { age }\end{array}$ & $\begin{array}{l}1-\sigma \\
\text { error }\end{array}$ & $\begin{array}{l}\text { Material } \\
\text { dated }^{\mathrm{a}}\end{array}$ & Context & Reference \\
\hline \multicolumn{8}{|c|}{$\begin{array}{l}\text { Prince William Sound segment } \\
\text { "Outer coast" }\end{array}$} \\
\hline COR 001 & Palugvik & P-192 & 1727 & 105 & WD & $\begin{array}{l}\text { house post? (in- } \\
\text { ner wood) }\end{array}$ & Clark 1984 \\
\hline COR 001 & Palugvik & P-173 & 2265 & 112 & WD & $\begin{array}{l}\text { shovel (paraffin } \\
\text { treated) }\end{array}$ & Clark 1984 \\
\hline COR 038 & $\begin{array}{l}\text { Hawkins Is. } \\
\text { (“Tauxtvik") } \\
\text { ("C") }\end{array}$ & Beta-23369 & 570 & 120 & $?$ & & Dotter 1988 \\
\hline COR 038 & $\begin{array}{l}\text { Hawkins Is. } \\
\text { (“Tauxtvik") } \\
\text { ("C") }\end{array}$ & Beta-23370 & 610 & 70 & $?$ & & Dotter 1988 \\
\hline COR 080 & Hawkins Island & WSU-2240 & 385 & 100 & $?$ & & Dotter 1988 \\
\hline COR 081 & Little Nuchek & WSU-2239 & 460 & 90 & $?$ & intertidal test pit & Dotter 1988 \\
\hline COR $318 ?$ & $\begin{array}{l}\text { Orca Inlet } \\
\text { ("B") }\end{array}$ & Beta-23380 & 350 & 60 & $?$ & & Dotter 1988 \\
\hline SEW 068 & $\begin{array}{l}\text { Kake Cove, } \\
\text { Chenega I. }\end{array}$ & GX-17343 & 1665 & 65 & WD & $\begin{array}{l}\text { wooden arti- } \\
\text { facts in peat just } \\
\text { below present } \\
\text { sandy cobble } \\
\text { beach }\end{array}$ & Reger et al. 1992 \\
\hline SEW 068 & $\begin{array}{l}\text { Kake Cove, } \\
\text { Chenega I. }\end{array}$ & GX-17342 & 1985 & 65 & WD & $\begin{array}{l}\text { wooden arti- } \\
\text { facts just below } \\
\text { present sandy } \\
\text { cobble beach }\end{array}$ & Reger et al. 1992 \\
\hline $\begin{array}{l}\text { SEW 080/ } \\
081 / 082\end{array}$ & $\begin{array}{l}\text { Montague Is- } \\
\text { land ("L") }\end{array}$ & Beta- 23372 & 190 & 70 & $\mathrm{CH}$ & & Dotter 1988 \\
\hline $\begin{array}{l}\text { SEW 080/ } \\
081 / 082\end{array}$ & $\begin{array}{l}\text { Montague Is- } \\
\text { land ("L") }\end{array}$ & Beta-23378 & 310 & 50 & $\mathrm{CH}$ & & Dotter 1988 \\
\hline $\begin{array}{l}\text { SEW 080/ } \\
081 / 082\end{array}$ & $\begin{array}{l}\text { Montague Is- } \\
\text { land ("L") }\end{array}$ & Beta-23371 & 340 & 80 & $\mathrm{CH}$ & & Dotter 1988 \\
\hline $\begin{array}{l}\text { SEW 080/ } \\
081 / 082\end{array}$ & $\begin{array}{l}\text { Montague Is- } \\
\text { land ("L") }\end{array}$ & Beta-23373 & 550 & 80 & $\mathrm{CH}$ & & Dotter 1988 \\
\hline SEW 234 & & WSU-2913 & 95 & 65 & $\mathrm{CH}$ & & Dotter 1988 \\
\hline SEW 234 & & WSU-2911 & 315 & 65 & $\mathrm{CH}$ & & Dotter 1988 \\
\hline SEW 234 & & WSU-2910 & 695 & 40 & $\mathrm{CH}$ & & Dotter 1988 \\
\hline SEW 430 & & Beta-42077 & 660 & 80 & $\mathrm{CH}$ & rockshelter & $\begin{array}{l}\text { Haggarty et al. } \\
1991\end{array}$ \\
\hline SEW 440 & Eleanor I. & Beta-78756 & 280 & 60 & $\mathrm{CH}$ & $\begin{array}{l}\text { cultural; coin- } \\
\text { cides strati- } \\
\text { graphically with } \\
\text { patchy tephra in } \\
\text { northern part of } \\
\text { site (= Valdez } \\
\text { ash?) }\end{array}$ & $\begin{array}{l}\text { Yarborough } \\
1997\end{array}$ \\
\hline SEW 440 & Eleanor I. & Beta-78760 & 380 & 60 & $\mathrm{CH}$ & cultural & $\begin{array}{l}\text { Yarborough } \\
1997\end{array}$ \\
\hline SEW 440 & Eleanor I. & Beta-78759 & 400 & 50 & $\mathrm{CH}$ & cultural & $\begin{array}{l}\text { Yarborough } \\
1997\end{array}$ \\
\hline SEW 440 & Eleanor I. & Beta-97208 & 530 & 60 & $\mathrm{CH}$ & $\begin{array}{l}\text { cultural; over- } \\
\text { lies bedrock and } \\
\text { predates heavy } \\
\text { FCR deposition } \\
\text { at eastern edge } \\
\text { of site }\end{array}$ & $\begin{array}{l}\text { Yarborough } \\
1997\end{array}$ \\
\hline SEW 440 & Eleanor I. & Beta-97209 & 1030 & 100 & $\mathrm{CH}$ & cultural & $\begin{array}{l}\text { Yarborough } \\
1997\end{array}$ \\
\hline
\end{tabular}


Appendix B Late Holocene ${ }^{14} \mathrm{C}$ ages from prehistoric coastal archaeological sites at the Alaska subduction zone. (Continued)

\begin{tabular}{|c|c|c|c|c|c|c|c|}
\hline $\begin{array}{l}\text { AHRS nr } \\
(49-)\end{array}$ & Site name & Lab nr & $\begin{array}{l}{ }^{14} \mathrm{C} \\
\text { age }\end{array}$ & $\begin{array}{l}1-\sigma \\
\text { error }\end{array}$ & $\begin{array}{l}\text { Material } \\
\text { dated }^{\mathrm{a}}\end{array}$ & Context & Reference \\
\hline SEW 440 & Eleanor I. & Beta-78758 & 1820 & 60 & $\mathrm{CH}$ & $\begin{array}{l}\text { cultural, in } \\
\text { gravel layer at } \\
64 \mathrm{~cm} \text { ? (N16- } \\
\text { E27); also dates } \\
\text { underlying te- } \\
\text { phra (White } \\
\text { River north lobe } \\
=1885 \mathrm{BP} \text { ) }\end{array}$ & $\begin{array}{l}\text { Yarborough } \\
1997\end{array}$ \\
\hline SEW 488 & Knight I. & Beta-89039 & 250 & 50 & $\mathrm{CH}$ & cultural & $\begin{array}{l}\text { Yarborough } \\
1997\end{array}$ \\
\hline SEW 488 & Knight I. & Beta-78764 & 300 & 50 & $\mathrm{CH}$ & cultural & $\begin{array}{l}\text { Yarborough } \\
1997\end{array}$ \\
\hline SEW 488 & Knight I. & Beta-78761 & 350 & 50 & $\mathrm{CH}$ & cultural & $\begin{array}{l}\text { Yarborough } \\
1997\end{array}$ \\
\hline SEW 488 & Knight I. & Beta- 89040 & 360 & 60 & $\mathrm{CH}$ & cultural & $\begin{array}{l}\text { Yarborough } \\
1997\end{array}$ \\
\hline SEW 488 & Knight I. & Beta-78768 & 380 & 50 & $\mathrm{CH}$ & cultural & $\begin{array}{l}\text { Yarborough } \\
1997\end{array}$ \\
\hline SEW 488 & Knight I. & Beta- 89043 & 430 & 50 & $\mathrm{CH}$ & cultural & $\begin{array}{l}\text { Yarborough } \\
1997\end{array}$ \\
\hline SEW 488 & Knight I. & Beta-89044 & 430 & 50 & $\mathrm{CH}$ & cultural & $\begin{array}{l}\text { Yarborough } \\
1997\end{array}$ \\
\hline SEW 488 & Knight I. & Beta-78767 & 460 & 60 & $\mathrm{CH}$ & cultural & $\begin{array}{l}\text { Yarborough } \\
1997\end{array}$ \\
\hline SEW 488 & Knight I. & Beta-89046 & 520 & 50 & $\mathrm{CH}$ & cultural & $\begin{array}{l}\text { Yarborough } \\
1997\end{array}$ \\
\hline SEW 488 & Knight I. & Beta- 89045 & 560 & 60 & $\mathrm{CH}$ & cultural & $\begin{array}{l}\text { Yarborough } \\
1997\end{array}$ \\
\hline SEW 488 & Knight I. & Beta-89047 & 560 & 70 & $\mathrm{CH}$ & cultural & $\begin{array}{l}\text { Yarborough } \\
1997\end{array}$ \\
\hline SEW 488 & Knight I. & Beta-89055 & 570 & 70 & $\mathrm{CH}$ & cultural & $\begin{array}{l}\text { Yarborough } \\
1997\end{array}$ \\
\hline SEW 488 & Knight I. & Beta-89052 & 590 & 60 & $\mathrm{CH}$ & cultural & $\begin{array}{l}\text { Yarborough } \\
1997\end{array}$ \\
\hline SEW 488 & Knight I. & Beta-78763 & 600 & 60 & $\mathrm{CH}$ & cultural & $\begin{array}{l}\text { Yarborough } \\
1997\end{array}$ \\
\hline SEW 488 & Knight I. & Beta-89038 & 600 & 60 & $\mathrm{CH}$ & cultural & $\begin{array}{l}\text { Yarborough } \\
1997\end{array}$ \\
\hline SEW 488 & Knight I. & Beta-78762 & 610 & 60 & $\mathrm{CH}$ & cultural & $\begin{array}{l}\text { Yarborough } \\
1997\end{array}$ \\
\hline SEW 488 & Knight I. & Beta-89054 & 620 & 80 & $\mathrm{CH}$ & cultural & $\begin{array}{l}\text { Yarborough } \\
1997\end{array}$ \\
\hline SEW 488 & Knight I. & Beta-89051 & 700 & 60 & $\mathrm{CH}$ & cultural & $\begin{array}{l}\text { Yarborough } \\
1997\end{array}$ \\
\hline SEW 488 & Knight I. & Beta-78766 & 810 & 50 & $\mathrm{CH}$ & cultural & $\begin{array}{l}\text { Yarborough } \\
1997\end{array}$ \\
\hline SEW 488 & Knight I. & Beta- 89048 & 820 & 60 & $\mathrm{CH}$ & cultural & $\begin{array}{l}\text { Yarborough } \\
1997\end{array}$ \\
\hline SEW 488 & Knight I. & Beta-78765 & 900 & 70 & $\mathrm{CH}$ & cultural & $\begin{array}{l}\text { Yarborough } \\
1997\end{array}$ \\
\hline SEW 488 & Knight I. & Beta-89049 & 910 & 90 & $\mathrm{CH}$ & cultural & $\begin{array}{l}\text { Yarborough } \\
1997\end{array}$ \\
\hline SEW 488 & Knight I. & Beta- 89050 & 990 & 60 & $\mathrm{CH}$ & cultural & $\begin{array}{l}\text { Yarborough } \\
1997\end{array}$ \\
\hline
\end{tabular}


Appendix B Late Holocene ${ }^{14} \mathrm{C}$ ages from prehistoric coastal archaeological sites at the Alaska subduction zone. (Continued)

\begin{tabular}{|c|c|c|c|c|c|c|c|}
\hline $\begin{array}{l}\text { AHRS nr } \\
(49-)\end{array}$ & Site name & Lab nr & $\begin{array}{l}{ }^{14} \mathrm{C} \\
\text { age }\end{array}$ & $\begin{array}{l}1-\sigma \\
\text { error }\end{array}$ & $\begin{array}{l}\text { Material } \\
\text { dated }^{\mathrm{a}}\end{array}$ & Context & Reference \\
\hline SEW 488 & Knight I. & Beta- 89056 & 1130 & 80 & $\mathrm{CH}$ & $\begin{array}{l}\text { cultural; dates } \\
\text { pumice (varies } \\
\text { from } 90-140 \\
\text { cm depth) }\end{array}$ & $\begin{array}{l}\text { Yarborough } \\
1997\end{array}$ \\
\hline SEW 488 & Knight I. & Beta-89057 & 1290 & 50 & $\mathrm{CH}$ & cultural & $\begin{array}{l}\text { Yarborough } \\
1997\end{array}$ \\
\hline SEW 488 & Knight I. & Beta-89042 & 1680 & 50 & $\mathrm{CH}$ & $\begin{array}{l}\text { from peat; occu- } \\
\text { pation of site } \\
\text { uncertain }\end{array}$ & $\begin{array}{l}\text { Yarborough } \\
1997\end{array}$ \\
\hline SEW 488 & Knight I. & Beta- 89058 & 2680 & 60 & $\mathrm{CH}$ & $\begin{array}{l}\text { occupational } \\
\text { extent unknown }\end{array}$ & $\begin{array}{l}\text { Yarborough } \\
1997\end{array}$ \\
\hline SEW 548 & $\begin{array}{l}\text { Icy Bay islet } \\
\text { ("I") }\end{array}$ & Beta-23376 & 440 & 80 & $\mathrm{CH}$ & & Dotter 1988 \\
\hline SEW 548 & $\begin{array}{l}\text { Icy Bay islet } \\
\text { ("I") }\end{array}$ & Beta-97210 & 990 & 80 & $\mathrm{CH}$ & $\begin{array}{l}\text { non-cultural } \\
\text { layer? (70-90 } \\
\text { cm in N25E33) }\end{array}$ & $\begin{array}{l}\text { Yarborough } \\
1997\end{array}$ \\
\hline \multicolumn{8}{|c|}{ "Inner coast" } \\
\hline ANC 589 & $\begin{array}{l}\text { College Fjord } \\
\text { ("A") }\end{array}$ & Beta-18573 & 460 & 70 & $?$ & $\begin{array}{l}\text { hearth in inter- } \\
\text { tidal test pit; } \\
\text { charcoal inter- } \\
\text { layered with } \\
\text { fine sand }\end{array}$ & Dotter 1988 \\
\hline SEW 056 & Uqciuvit & WSU-3938 & 110 & 90 & W & $\begin{array}{l}\text { cultural; ques- } \\
\text { tionable age }\end{array}$ & $\begin{array}{l}\text { Yarborough \& } \\
\text { Yarborough } \\
1991\end{array}$ \\
\hline SEW 056 & Uqciuvit & WSU-3914 & 200 & 90 & $?$ & $\begin{array}{l}\text { burial from final } \\
\text { stage of occupa- } \\
\text { tion }\end{array}$ & $\begin{array}{l}\text { Yarborough \& } \\
\text { Yarborough } \\
1991\end{array}$ \\
\hline SEW 056 & Uqciuvit & WSU-3913 & 295 & 90 & W & house "floor"? & $\begin{array}{l}\text { Yarborough \& } \\
\text { Yarborough } \\
1991\end{array}$ \\
\hline SEW 056 & Uqciuvit & Beta-30558 & 590 & 60 & $?$ & house pit & $\begin{array}{l}\text { Yarborough \& } \\
\text { Yarborough } \\
1991\end{array}$ \\
\hline SEW 056 & Uqciuvit & WSU-3940 & 830 & 65 & $?$ & house "floor"? & $\begin{array}{l}\text { Yarborough \& } \\
\text { Yarborough } \\
1991\end{array}$ \\
\hline SEW 056 & Uqciuvit & WSU-3915 & 960 & 60 & $\mathrm{CH}$ ? & cultural & $\begin{array}{l}\text { Yarborough \& } \\
\text { Yarborough } \\
1991\end{array}$ \\
\hline SEW 056 & Uqciuvit & WSU-3911 & 1020 & 60 & $\mathrm{CH} ?$ & cultural & $\begin{array}{l}\text { Yarborough \& } \\
\text { Yarborough } \\
1991\end{array}$ \\
\hline SEW 056 & Uqciuvit & WSU-3937 & 1400 & 70 & $\mathrm{CH} ?$ & $\begin{array}{l}\text { cultural from } \\
\text { upper EPA strat. } \\
\text { level in higher } \\
\text { part of site }\end{array}$ & $\begin{array}{l}\text { Yarborough \& } \\
\text { Yarborough } \\
1991\end{array}$ \\
\hline SEW 056 & Uqciuvit & WSU-3941 & 1510 & 120 & $\mathrm{CH}$ ? & $\begin{array}{l}\text { cultural; above } \\
\text { gravel }\end{array}$ & $\begin{array}{l}\text { Yarborough \& } \\
\text { Yarborough } \\
1991\end{array}$ \\
\hline SEW 056 & Uqciuvit & Beta-28804 & 2000 & 110 & $\mathrm{CH}$ ? & $\begin{array}{l}\text { cultural; below } \\
\text { gravel }\end{array}$ & $\begin{array}{l}\text { Yarborough \& } \\
\text { Yarborough } \\
1991\end{array}$ \\
\hline SEW 056 & Uqciuvit & WSU-3939 & 2310 & 60 & $\mathrm{CH}$ ? & $\begin{array}{l}\text { cultural; below } \\
\text { gravel }\end{array}$ & $\begin{array}{l}\text { Yarborough \& } \\
\text { Yarborough } \\
1991\end{array}$ \\
\hline
\end{tabular}


Appendix B Late Holocene ${ }^{14} \mathrm{C}$ ages from prehistoric coastal archaeological sites at the Alaska subduction zone. (Continued)

\begin{tabular}{|c|c|c|c|c|c|c|c|}
\hline $\begin{array}{l}\text { AHRS nr } \\
(49-)\end{array}$ & Site name & Lab nr & $\begin{array}{l}{ }^{14} \mathrm{C} \\
\text { age }\end{array}$ & $\begin{array}{l}1-\sigma \\
\text { error }\end{array}$ & $\begin{array}{l}\text { Material } \\
\text { dated }^{\mathrm{a}}\end{array}$ & Context & Reference \\
\hline SEW 056 & Uqciuvit & WSU-3916 & 2370 & 70 & $\mathrm{CH}$ ? & $\begin{array}{l}\text { cultural; below } \\
\text { gravel }\end{array}$ & $\begin{array}{l}\text { Yarborough \& } \\
\text { Yarborough } \\
1991\end{array}$ \\
\hline SEW 056 & Uqciuvit & WSU-3936 & 3380 & 100 & $\mathrm{CH} ?$ & $\begin{array}{l}\text { in oldest stra- } \\
\text { tum just above } \\
\text { grey silt loam }\end{array}$ & $\begin{array}{l}\text { Yarborough \& } \\
\text { Yarborough } \\
1991\end{array}$ \\
\hline SEW 056 & Uqciuvit & WSU-3912 & 3810 & 90 & $\mathrm{CH} ?$ & $\begin{array}{l}\text { in oldest stra- } \\
\text { tum at base of } \\
\text { pit; few artifacts }\end{array}$ & $\begin{array}{l}\text { Yarborough \& } \\
\text { Yarborough } \\
1991\end{array}$ \\
\hline $\begin{array}{l}\text { SEW 349/ } \\
553 / 554 / \\
555\end{array}$ & $\begin{array}{l}\text { Unakwik Inlet } \\
\text { ("F") }\end{array}$ & Beta-23381 & 530 & 80 & $\mathrm{CH}$ & & Dotter 1988 \\
\hline $\begin{array}{l}\text { SEW 349/ } \\
553 / 554 / \\
555\end{array}$ & $\begin{array}{l}\text { Unakwik Inlet } \\
\text { ("F") }\end{array}$ & Beta-23366 & 1090 & 70 & $\mathrm{CH}$ & & Dotter 1988 \\
\hline \multicolumn{8}{|c|}{$\begin{array}{l}\text { Kenai segment } \\
\text { "Outer coast" }\end{array}$} \\
\hline SEL 188 & $\begin{array}{l}\text { MacArthur } \\
\text { Pass }\end{array}$ & Beta-39475 & 620 & 50 & $\mathrm{CH}$ & & $\begin{array}{l}\text { Schaaf \& } \\
\text { Johnson 1990; } \\
\text { Betts et al. 1991; } \\
\text { Erlandson et al. } \\
1992\end{array}$ \\
\hline SEL 188 & $\begin{array}{l}\text { MacArthur } \\
\text { Pass }\end{array}$ & Beta-39476 & 560 & 50 & $\mathrm{CH}$ & & $\begin{array}{l}\text { Schaaf \& } \\
\text { Johnson 1990; } \\
\text { Betts et al. 1991 }\end{array}$ \\
\hline SEL 188 & $\begin{array}{l}\text { MacArthur } \\
\text { Pass }\end{array}$ & Beta-39477 & 710 & 50 & $\mathrm{CH}$ & & $\begin{array}{l}\text { Schaaf \& } \\
\text { Johnson 1990; } \\
\text { Betts et al. 1991 }\end{array}$ \\
\hline SEL 188 & $\begin{array}{l}\text { MacArthur } \\
\text { Pass }\end{array}$ & Beta-39478 & 700 & 90 & $\mathrm{CH}$ & & $\begin{array}{l}\text { Schaaf \& } \\
\text { Johnson 1990; } \\
\text { Betts et al. 1991 }\end{array}$ \\
\hline SEL 188 & $\begin{array}{l}\text { MacArthur } \\
\text { Pass }\end{array}$ & GX-17226 & 825 & 65 & $\mathrm{CH}$ & $\begin{array}{l}\text { split w/ GX- } \\
17227\end{array}$ & $\begin{array}{l}\text { Dekin et al. } \\
\text { 1993; Crowell \& } \\
\text { Mann } 1996\end{array}$ \\
\hline SEL 188 & $\begin{array}{l}\text { MacArthur } \\
\text { Pass }\end{array}$ & GX-17227 & 660 & 60 & $\mathrm{CH}$ & $\begin{array}{l}\text { split w/ GX- } \\
17226\end{array}$ & $\begin{array}{l}\text { Dekin et al. } \\
\text { 1993; Crowell \& } \\
\text { Mann } 1996\end{array}$ \\
\hline SEL 188 & $\begin{array}{l}\text { MacArthur } \\
\text { Pass }\end{array}$ & $\begin{array}{l}\text { wt. mean \& sd } \\
\text { GX-17232 }\end{array}$ & $\begin{array}{l}736 \\
855\end{array}$ & $\begin{array}{r}88 \\
115\end{array}$ & $\mathrm{CH}$ & $\begin{array}{l}\text { split w/ GX- } \\
17233\end{array}$ & $\begin{array}{l}\text { Dekin et al. } \\
\text { 1993; Crowell \& } \\
\text { Mann } 1996\end{array}$ \\
\hline SEL 188 & $\begin{array}{l}\text { MacArthur } \\
\text { Pass }\end{array}$ & GX-17234 & 1005 & 65 & WD & $\begin{array}{l}\text { split w/ GX- } \\
17235\end{array}$ & $\begin{array}{l}\text { Dekin et al. } \\
\text { 1993; Crowell \& } \\
\text { Mann } 1996\end{array}$ \\
\hline SEL 188 & $\begin{array}{l}\text { MacArthur } \\
\text { Pass }\end{array}$ & GX-17235 & 1210 & 65 & WD & $\begin{array}{l}\text { split w/ GX- } \\
17234\end{array}$ & $\begin{array}{l}\text { Dekin et al. } \\
\text { 1993; Crowell \& } \\
\text { Mann } 1996\end{array}$ \\
\hline SEL 188 & $\begin{array}{l}\text { MacArthur } \\
\text { Pass }\end{array}$ & $\begin{array}{l}\text { wt. mean \& sd } \\
\text { GX-17236 }\end{array}$ & $\begin{array}{r}1108 \\
585\end{array}$ & $\begin{array}{r}44 \\
105\end{array}$ & $\mathrm{CH}$ & $\begin{array}{l}\text { split w/ GX- } \\
17237\end{array}$ & $\begin{array}{l}\text { Dekin et al. } \\
\text { 1993; Crowell \& } \\
\text { Mann } 1996\end{array}$ \\
\hline SEL 188 & $\begin{array}{l}\text { MacArthur } \\
\text { Pass }\end{array}$ & GX-17237 & 670 & 105 & $\mathrm{CH}$ & $\begin{array}{l}\text { split w/ GX- } \\
17236\end{array}$ & $\begin{array}{l}\text { Dekin et al. } \\
\text { 1993; Crowell \& } \\
\text { Mann } 1996\end{array}$ \\
\hline
\end{tabular}


Appendix B Late Holocene ${ }^{14} \mathrm{C}$ ages from prehistoric coastal archaeological sites at the Alaska subduction zone. (Continued)

\begin{tabular}{|c|c|c|c|c|c|c|c|}
\hline $\begin{array}{l}\text { AHRS nr } \\
(49-)\end{array}$ & Site name & Lab nr & $\begin{array}{l}{ }^{14} \mathrm{C} \\
\text { age }\end{array}$ & $\begin{array}{l}1-\sigma \\
\text { error }\end{array}$ & $\begin{array}{l}\text { Material } \\
\text { dated }^{\mathrm{a}}\end{array}$ & Context & Reference \\
\hline SEL 188 & $\begin{array}{l}\text { MacArthur } \\
\text { Pass }\end{array}$ & GX-17238 & 770 & 65 & $\mathrm{CH}$ & $\begin{array}{l}\text { split w/ GX- } \\
17239\end{array}$ & $\begin{array}{l}\text { Dekin et al. } \\
\text { 1993; Crowell \& } \\
\text { Mann } 1996\end{array}$ \\
\hline SEL 188 & $\begin{array}{l}\text { MacArthur } \\
\text { Pass }\end{array}$ & GX-17239 & 925 & 105 & $\mathrm{CH}$ & $\begin{array}{l}\text { split w/ GX- } \\
17238\end{array}$ & $\begin{array}{l}\text { Dekin et al. } \\
\text { 1993; Crowell \& } \\
\text { Mann } 1996\end{array}$ \\
\hline SEL 188 & $\begin{array}{l}\text { MacArthur } \\
\text { Pass }\end{array}$ & $\begin{array}{l}\text { wt. mean \& sd } \\
\text { Beta-39479 }\end{array}$ & $\begin{array}{r}813 \\
1350\end{array}$ & $\begin{array}{l}55 \\
70\end{array}$ & $\mathrm{CH}$ & & $\begin{array}{l}\text { Schaaf \& } \\
\text { Johnson 1990; } \\
\text { Betts et al. 1991 }\end{array}$ \\
\hline SEL 188 & $\begin{array}{l}\text { MacArthur } \\
\text { Pass }\end{array}$ & GX-17228 & 1690 & 140 & $\mathrm{CH}$ & $\begin{array}{l}\text { split w/ GX- } \\
17229\end{array}$ & $\begin{array}{l}\text { Dekin et al. } \\
\text { 1993; Crowell \& } \\
\text { Mann } 1996\end{array}$ \\
\hline SEL 188 & $\begin{array}{l}\text { MacArthur } \\
\text { Pass }\end{array}$ & GX-17229 & 1710 & 120 & $\mathrm{CH}$ & $\begin{array}{l}\text { split w/ GX- } \\
17228\end{array}$ & $\begin{array}{l}\text { Dekin et al. } \\
\text { 1993; Crowell \& } \\
\text { Mann } 1996\end{array}$ \\
\hline SEL 215 & $\begin{array}{l}\text { Berger Bay, } \\
\text { Nuka I. }\end{array}$ & $\begin{array}{l}\text { wt. mean \& sd } \\
\text { GX-17335 }\end{array}$ & $\begin{array}{r}1700 \\
670\end{array}$ & $\begin{array}{l}90 \\
60\end{array}$ & $\mathrm{CH}$ & $\begin{array}{l}\text { from artifact- } \\
\text { bearing upper } \\
\text { peat }\end{array}$ & Reger et al. 1992 \\
\hline SEL 215 & $\begin{array}{l}\text { Berger Bay, } \\
\text { Nuka I. }\end{array}$ & GX-17336 & 665 & 105 & $\mathrm{CH}$ & $\begin{array}{l}\text { from artifact- } \\
\text { bearing upper } \\
\text { peat }\end{array}$ & Reger et al. 1992 \\
\hline SEL 215 & $\begin{array}{l}\text { Berger Bay, } \\
\text { Nuka I. }\end{array}$ & GX-17337 & 840 & 60 & $\mathrm{CH}$ & $\begin{array}{l}\text { from artifact- } \\
\text { bearing upper } \\
\text { peat }\end{array}$ & Reger et al. 1992 \\
\hline SEL 215 & $\begin{array}{l}\text { Berger Bay, } \\
\text { Nuka I. }\end{array}$ & GX-17338 & 655 & 100 & WD & $\begin{array}{l}\text { from artifact- } \\
\text { bearing upper } \\
\text { peat }\end{array}$ & Reger et al. 1992 \\
\hline SEL 215 & $\begin{array}{l}\text { Berger Bay, } \\
\text { Nuka I. }\end{array}$ & GX-17339 & 920 & 60 & WD & $\begin{array}{l}\text { from artifact- } \\
\text { bearing upper } \\
\text { peat }\end{array}$ & Reger et al. 1992 \\
\hline SEL 215 & $\begin{array}{l}\text { Berger Bay, } \\
\text { Nuka I. }\end{array}$ & GX-17340 & 425 & 105 & WD & $\begin{array}{l}\text { from artifact- } \\
\text { bearing upper } \\
\text { peat }\end{array}$ & Reger et al. 1992 \\
\hline SEL 215 & $\begin{array}{l}\text { Berger Bay, } \\
\text { Nuka I. }\end{array}$ & GX-17341 & 635 & 60 & WD & $\begin{array}{l}\text { from artifact- } \\
\text { bearing upper } \\
\text { peat }\end{array}$ & Reger et al. 1992 \\
\hline XBS 020 & $\begin{array}{l}\text { Northwest La- } \\
\text { goon }\end{array}$ & Beta-23383 & 140 & 60 & $\mathrm{CH}$ & & $\begin{array}{l}\text { Dotter 1988; } \\
\text { Kent \& McCal- } \\
\text { lum } 1991\end{array}$ \\
\hline XBS 020 & $\begin{array}{l}\text { Northwest La- } \\
\text { goon }\end{array}$ & Beta- 67272 & 240 & 70 & $\mathrm{CH}$ & & $\begin{array}{l}\text { Crowell \& Mann } \\
1996\end{array}$ \\
\hline XBS 020 & $\begin{array}{l}\text { Northwest La- } \\
\text { goon }\end{array}$ & Beta-23382 & 320 & 50 & $\mathrm{CH}$ & & $\begin{array}{l}\text { Dotter 1988; } \\
\text { Kent \& McCal- } \\
\text { lum } 1991\end{array}$ \\
\hline XBS 020 & $\begin{array}{l}\text { Northwest La- } \\
\text { goon }\end{array}$ & Beta-67267 & 580 & 80 & $\mathrm{CH}$ & & $\begin{array}{l}\text { Crowell \& Mann } \\
1996\end{array}$ \\
\hline XBS 020 & $\begin{array}{l}\text { Northwest La- } \\
\text { goon }\end{array}$ & Beta-67271 & 610 & 90 & $\mathrm{CH}$ & & $\begin{array}{l}\text { Crowell \& Mann } \\
1996\end{array}$ \\
\hline XBS 020 & $\begin{array}{l}\text { Northwest La- } \\
\text { goon }\end{array}$ & Beta-67269 & 660 & 90 & $\mathrm{CH}$ & & $\begin{array}{l}\text { Crowell \& Mann } \\
1996\end{array}$ \\
\hline XBS 020 & $\begin{array}{l}\text { Northwest La- } \\
\text { goon }\end{array}$ & Beta- 67270 & 690 & 90 & $\mathrm{CH}$ & & $\begin{array}{l}\text { Crowell \& Mann } \\
1996\end{array}$ \\
\hline XBS 020 & $\begin{array}{l}\text { Northwest La- } \\
\text { goon }\end{array}$ & Beta-67268 & 830 & 70 & $\mathrm{CH}$ & & $\begin{array}{l}\text { Crowell \& Mann } \\
1996\end{array}$ \\
\hline
\end{tabular}


Appendix B Late Holocene ${ }^{14} \mathrm{C}$ ages from prehistoric coastal archaeological sites at the Alaska subduction zone. (Continued)

\begin{tabular}{|c|c|c|c|c|c|c|c|}
\hline $\begin{array}{l}\text { AHRS nr } \\
(49-)\end{array}$ & Site name & Lab nr & $\begin{array}{l}{ }^{14} \mathrm{C} \\
\text { age }\end{array}$ & $\begin{array}{l}1-\sigma \\
\text { error }\end{array}$ & $\begin{array}{l}\text { Material } \\
\text { dated }^{\mathrm{a}}\end{array}$ & Context & Reference \\
\hline XBS 030 & $\begin{array}{l}\text { Bear Cove Vil- } \\
\text { lage }\end{array}$ & Beta-222209 & 130 & 40 & $\mathrm{CH}$ & $\begin{array}{l}\text { Phase } 3 \text { (house } \\
\text { floor in struc- } \\
\text { ture 19) }\end{array}$ & $\begin{array}{l}\text { A Crowell (un- } \\
\text { published data) }\end{array}$ \\
\hline XBS 030 & $\begin{array}{l}\text { Bear Cove Vil- } \\
\text { lage }\end{array}$ & Beta- 222210 & 260 & 50 & $\mathrm{CH}$ & $\begin{array}{l}\text { Phase } 3 \text { (house } \\
\text { floor in struc- } \\
\text { ture } 20 \text { ) }\end{array}$ & $\begin{array}{l}\text { A Crowell (un- } \\
\text { published data) }\end{array}$ \\
\hline XBS 030 & $\begin{array}{l}\text { Bear Cove Vil- } \\
\text { lage }\end{array}$ & Beta-67273 & 590 & 50 & $\mathrm{CH}$ & $\begin{array}{l}\text { Phase } 2 \text { (upper } \\
\text { house floor in } \\
\text { structure } 7 \text {; stra- } \\
\text { tum 3) }\end{array}$ & $\begin{array}{l}\text { Crowell \& Mann } \\
1996\end{array}$ \\
\hline XBS 030 & $\begin{array}{l}\text { Bear Cove Vil- } \\
\text { lage }\end{array}$ & Beta-67274 & 640 & 110 & $\mathrm{CH}$ & $\begin{array}{l}\text { Phase } 2 \text { (upper } \\
\text { house floor in } \\
\text { structure } 7 \text {; stra- } \\
\text { tum 3) }\end{array}$ & $\begin{array}{l}\text { Crowell \& Mann } \\
1996\end{array}$ \\
\hline XBS 030 & $\begin{array}{l}\text { Bear Cove Vil- } \\
\text { lage }\end{array}$ & Beta-170800 & 710 & 60 & $\mathrm{CM}$ & $\begin{array}{l}\text { Phase } 1 \text { (lower } \\
\text { house floor; } \\
\text { bottom of stra- } \\
\text { tum } 5 \text { in struc- } \\
\text { ture } 7 \text { ) }\end{array}$ & Crowell 2003 \\
\hline XBS 030 & $\begin{array}{l}\text { Bear Cove Vil- } \\
\text { lage }\end{array}$ & Beta-170803 & 720 & 70 & $\mathrm{CM}$ & $\begin{array}{l}\text { Phase } 1 \text { (bottom } \\
\text { of feature B, } \\
\text { stratum } 3 \text { in } \\
\text { structure } 8 \text { ) }\end{array}$ & Crowell 2003 \\
\hline XBS 030 & $\begin{array}{l}\text { Bear Cove Vil- } \\
\text { lage }\end{array}$ & Beta-170797 & 860 & 70 & $\mathrm{CM}$ & $\begin{array}{l}\text { Phase } 1 \text { (lower } \\
\text { house floor; top } \\
\text { of stratum } 5 \text { in } \\
\text { structure } 7 \text { ) }\end{array}$ & Crowell 2003 \\
\hline XBS 030 & $\begin{array}{l}\text { Bear Cove Vil- } \\
\text { lage }\end{array}$ & Beta-170804 & 960 & 80 & $\mathrm{CM}$ & $\begin{array}{l}\text { charcoal lens } 10 \\
\text { cm below struc- } \\
\text { ture } 8 \text { house } \\
\text { floor }\end{array}$ & Crowell 2003 \\
\hline XBS 030 & $\begin{array}{l}\text { Bear Cove Vil- } \\
\text { lage }\end{array}$ & Beta-170805 & 1010 & 110 & $\mathrm{CM}$ & $\begin{array}{l}\text { charcoal lens } 60 \\
\text { cm below struc- } \\
\text { ture } 8 \text { house } \\
\text { floor }\end{array}$ & Crowell 2003 \\
\hline XBS 031 & $\begin{array}{l}\text { Verdant Cove } \\
\text { South Midden }\end{array}$ & Beta-67277 & 570 & 50 & $\mathrm{CH}$ & & $\begin{array}{l}\text { Crowell \& Mann } \\
1996\end{array}$ \\
\hline \multicolumn{8}{|c|}{ "Inner coast" } \\
\hline SEL 010 & $\begin{array}{l}\text { Halibut Cove } 1 \\
\text { (Pt. West) }\end{array}$ & WSU-3812 & 510 & 60 & $\mathrm{CH}$ & $\begin{array}{l}\text { house (hearth) - } \\
\text { above midden }\end{array}$ & $\begin{array}{l}\text { Mills 1994; } \\
\text { Reger \& Boraas } \\
1996\end{array}$ \\
\hline SEL 010 & $\begin{array}{l}\text { Halibut Cove } 1 \\
\text { (Pt. West) }\end{array}$ & WSU-3810 & 775 & 60 & $\mathrm{CH}$ & $\begin{array}{l}\text { house (hearth) - } \\
\text { above midden }\end{array}$ & $\begin{array}{l}\text { Mills 1994; } \\
\text { Reger \& Boraas } \\
1996\end{array}$ \\
\hline SEL 010 & $\begin{array}{l}\text { Halibut Cove } 1 \\
\text { (Pt. West) }\end{array}$ & WSU-3859 & 1100 & 60 & $\mathrm{CW}$ & $\begin{array}{l}\text { near top of mid- } \\
\text { den }\end{array}$ & $\begin{array}{l}\text { Mills 1994; } \\
\text { Reger \& Boraas } \\
1996\end{array}$ \\
\hline SEL 010 & $\begin{array}{l}\text { Halibut Cove } 1 \\
\text { (Pt. West) }\end{array}$ & WSU-3811 & 1940 & 70 & $\mathrm{CH}$ & base of midden & $\begin{array}{l}\text { Mills 1994; } \\
\text { Reger \& Boraas } \\
1996\end{array}$ \\
\hline SEL 027 & Port Graham & Beta-99311 & 500 & 60 & $\mathrm{CH}$ & $\begin{array}{l}\text { postdates site } \\
\text { occupation }\end{array}$ & $\begin{array}{l}\text { Workman \& } \\
\text { Workman } 1997\end{array}$ \\
\hline SEL 027 & Port Graham & Beta-99312 & 570 & 80 & $\mathrm{CH}$ & $\begin{array}{l}\text { cultural depos- } \\
\text { its }\end{array}$ & $\begin{array}{l}\text { Workman \& } \\
\text { Workman } 1997\end{array}$ \\
\hline SEL 027 & Port Graham & Beta-99310 & 610 & 60 & $\mathrm{CH}$ & $\begin{array}{l}\text { cultural depos- } \\
\text { its }\end{array}$ & $\begin{array}{l}\text { Workman \& } \\
\text { Workman } 1997\end{array}$ \\
\hline
\end{tabular}


Appendix B Late Holocene ${ }^{14} \mathrm{C}$ ages from prehistoric coastal archaeological sites at the Alaska subduction zone. (Continued)

\begin{tabular}{|c|c|c|c|c|c|c|c|}
\hline $\begin{array}{l}\text { AHRS nr } \\
(49-)\end{array}$ & Site name & Lab nr & $\begin{array}{l}{ }^{14} \mathrm{C} \\
\text { age }\end{array}$ & $\begin{array}{l}1-\sigma \\
\text { error }\end{array}$ & $\begin{array}{l}\text { Material } \\
\text { dated }^{\mathrm{a}}\end{array}$ & Context & Reference \\
\hline SEL 030 & $\begin{array}{l}\text { Cottonwood } \\
\text { Creek }\end{array}$ & S-1054 & 1555 & 75 & $\mathrm{CH}$ & midden & Mills 1994 \\
\hline SEL 030 & $\begin{array}{l}\text { Cottonwood } \\
\text { Creek }\end{array}$ & S-1042 & 1745 & 65 & $\mathrm{CW}$ & floor plank & Mills 1994 \\
\hline SEL 030 & $\begin{array}{l}\text { Cottonwood } \\
\text { Creek }\end{array}$ & S-1043 & 1750 & 125 & $\mathrm{CW}$ & floor plank & Mills 1994 \\
\hline SEL 033 & $\begin{array}{l}\text { Chugachik Is- } \\
\text { land }\end{array}$ & UGa-2344 & 1475 & 70 & $\mathrm{CH}$ & midden & Mills 1994 \\
\hline SEL 033 & $\begin{array}{l}\text { Chugachik Is- } \\
\text { land }\end{array}$ & S-1063 & 1705 & 65 & $\mathrm{CH}$ & midden & $\begin{array}{l}\text { Mills 1994; } \\
\text { Reger \& Boraas } \\
1996\end{array}$ \\
\hline SEL 033 & $\begin{array}{l}\text { Chugachik Is- } \\
\text { land }\end{array}$ & UGa-2342 & 1940 & 90 & $\mathrm{CH}$ & midden & Mills 1994 \\
\hline SEL 033 & $\begin{array}{l}\text { Chugachik Is- } \\
\text { land }\end{array}$ & S-1062 & 2310 & 65 & $\mathrm{BB}$ & midden & Mills 1994 \\
\hline SEL 033 & $\begin{array}{l}\text { Chugachik Is- } \\
\text { land }\end{array}$ & UGa-2343 & 2740 & 75 & WD & midden & Mills 1994 \\
\hline SEL 041 & $\begin{array}{l}\text { Fox Farm and } \\
\text { Bluff }\end{array}$ & UGa-2339 & 1090 & 195 & $\mathrm{CH}$ & midden & $\begin{array}{l}\text { Mills } 1994 \text { (re- } \\
\text { ject; too impre- } \\
\text { cise) }\end{array}$ \\
\hline SEL 041 & $\begin{array}{l}\text { Fox Farm and } \\
\text { Bluff }\end{array}$ & UGa-2340 & 1130 & 120 & $\mathrm{CH}$ & $\begin{array}{l}\text { occupation } \\
\text { layer }\end{array}$ & Mills 1994 \\
\hline SEL 041 & $\begin{array}{l}\text { Fox Farm and } \\
\text { Bluff }\end{array}$ & UGa-2341 & 1315 & 250 & $\mathrm{CH}$ & midden & $\begin{array}{l}\text { Mills } 1994 \text { (re- } \\
\text { ject; too impre- } \\
\text { cise) }\end{array}$ \\
\hline SEL 079 & Seal Beach & UGa-3635 & 1685 & 100 & $\mathrm{CH}$ & midden & Mills 1994 \\
\hline SEL 079 & Seal Beach & UGa-3636 & 2050 & 60 & $\mathrm{CH}$ & $\begin{array}{l}\text { lower compo- } \\
\text { nent }\end{array}$ & Mills 1994 \\
\hline SEL 245 & Sylva & Beta-58167 & 1020 & 60 & $\mathrm{CH}$ & $\begin{array}{l}\text { unknown cul- } \\
\text { tural affinity }\end{array}$ & Mills 1994 \\
\hline KEN 045 & Clam Gulch & I-12161 & 190 & 80 & $\mathrm{CH}$ & & Reger 1987 \\
\hline KEN 045 & Clam Gulch & I-12166 & 240 & 70 & $\mathrm{CH}$ & & Reger 1987 \\
\hline KEN 045 & Clam Gulch & I-12167 & 200 & 70 & $\mathrm{CH}$ & & Reger 1987 \\
\hline KEN 045 & Clam Gulch & Beta-6686 & 340 & 50 & $\mathrm{CH}$ & & Reger 1987 \\
\hline KEN 045 & Clam Gulch & I-12168 & 360 & 80 & $\mathrm{CH}$ & & Reger 1987 \\
\hline KEN 230 & $?$ & WSU-4142 & 350 & 90 & & & $\begin{array}{l}\text { Reger \& Boraas } \\
1996\end{array}$ \\
\hline KEN 230 & $?$ & WSU-4143 & 220 & 120 & & & $\begin{array}{l}\text { Reger \& Boraas } \\
1996\end{array}$ \\
\hline KEN 230 & $?$ & WSU-4144 & 310 & 90 & & & $\begin{array}{l}\text { Reger \& Boraas } \\
1996\end{array}$ \\
\hline KEN 232 & Nelson & WSU-4148 & 380 & 90 & & & $\begin{array}{l}\text { Reger \& Boraas } \\
1996\end{array}$ \\
\hline KEN 233 & Pelch & WSU-4147 & 540 & 90 & & & $\begin{array}{l}\text { Reger \& Boraas } \\
1996\end{array}$ \\
\hline KEN 233 & Pelch & WSU-4149 & 645 & 60 & & & $\begin{array}{l}\text { Reger \& Boraas } \\
1996\end{array}$ \\
\hline
\end{tabular}

Kodiak-Katmai segment

"Outer coast"

$\begin{array}{llllllll}\text { AFG 004 } & \text { Aleut Town } & \text { Beta-150811 } & 1090 & 80 & \text { CM } & \begin{array}{l}\text { hearth at south } \\ \text { end of excava- } \\ \text { tion }\end{array} & \begin{array}{l}\text { D Clark, p.c. to } \\ \text { Fitzhugh 2003 }\end{array} \\ \text { AFG 005 } & \text { Malina Creek } & ? & 500 & 50 & ? & & \end{array}$


Appendix B Late Holocene ${ }^{14} \mathrm{C}$ ages from prehistoric coastal archaeological sites at the Alaska subduction zone. (Continued)

\begin{tabular}{|c|c|c|c|c|c|c|c|}
\hline $\begin{array}{l}\text { AHRS nr } \\
(49-)\end{array}$ & Site name & Lab nr & $\begin{array}{l}{ }^{14} \mathrm{C} \\
\text { age }\end{array}$ & $\begin{array}{l}1-\sigma \\
\text { error }\end{array}$ & $\begin{array}{l}\text { Material } \\
\text { dated }^{\mathrm{a}}\end{array}$ & Context & Reference \\
\hline AFG 005 & Malina Creek & Beta-42073 & 620 & 70 & $?$ & & $\begin{array}{l}\text { Haggarty et al. } \\
\text { 1991; Mills } 1994\end{array}$ \\
\hline AFG 010 & Salmon Bend & Beta-170061 & 1330 & 60 & $\mathrm{CM}$ & $\begin{array}{l}\text { Top of fill in } \\
\text { main room, im- } \\
\text { mediately be- } \\
\text { fore tsunami }\end{array}$ & $\begin{array}{l}\text { D Clark, p.c. to } \\
\text { Fitzhugh } 2003\end{array}$ \\
\hline AFG 010 & Salmon Bend & Beta-170060 & 1400 & 80 & $\mathrm{CM}$ & $\begin{array}{l}\text { Annex room, } \\
\text { well above } \\
\text { floor, but well } \\
\text { below top }\end{array}$ & $\begin{array}{l}\text { D Clark, p.c. to } \\
\text { Fitzhugh } 2003\end{array}$ \\
\hline AFG 011 & & GaK-3803 & 3890 & 110 & $?$ & & $\begin{array}{l}\text { Clark 1997; } \\
\text { Mills } 1994\end{array}$ \\
\hline AFG 012 & & Beta-101917 & 280 & 60 & $\mathrm{CM}$ & Sq. 4 Midden & Partlow 2000 \\
\hline AFG 012 & & Beta-101914 & 310 & 40 & $\mathrm{CM}$ & $\begin{array}{l}\text { Sq. } 2 \text { House } \\
\text { hearth }\end{array}$ & Partlow 2000 \\
\hline AFG 012 & & Beta-101915 & 420 & 60 & $\mathrm{CM}$ & Sq. 1 & Partlow 2000 \\
\hline AFG 012 & & Beta-101916 & 450 & 60 & $\mathrm{CM}$ & $\begin{array}{l}\text { Sq. 2. Sub house } \\
\text { floor pit }\end{array}$ & Partlow 2000 \\
\hline AFG 015 & $\begin{array}{l}\text { Settlement } \\
\text { Point }\end{array}$ & Beta-101552 & 300 & 50 & $\mathrm{CH}$ & House 2 hearth & $\begin{array}{l}\text { Saltonstall \& } \\
\text { Carver } 2002\end{array}$ \\
\hline AFG 015 & $\begin{array}{l}\text { Settlement } \\
\text { Point }\end{array}$ & Beta-114205 & 300 & 50 & $\mathrm{CH}$ & House 6 hearth & $\begin{array}{l}\text { Saltonstall \& } \\
\text { Carver } 2002\end{array}$ \\
\hline AFG 015 & $\begin{array}{l}\text { Settlement } \\
\text { Point }\end{array}$ & Beta-114203 & 330 & 60 & $\mathrm{CH}$ & House 4 hearth & $\begin{array}{l}\text { Saltonstall \& } \\
\text { Carver } 2002\end{array}$ \\
\hline AFG 015 & $\begin{array}{l}\text { Settlement } \\
\text { Point }\end{array}$ & Beta-114098 & 340 & 60 & $\mathrm{CH}$ & Midden L2G & $\begin{array}{l}\text { Saltonstall \& } \\
\text { Carver } 2002\end{array}$ \\
\hline AFG 015 & $\begin{array}{l}\text { Settlement } \\
\text { Point }\end{array}$ & Beta-114097 & 350 & 70 & $\mathrm{CH}$ & House 3 hearth & $\begin{array}{l}\text { Saltonstall \& } \\
\text { Carver } 2002\end{array}$ \\
\hline AFG 015 & $\begin{array}{l}\text { Settlement } \\
\text { Point }\end{array}$ & Beta-114096 & 370 & 80 & $\mathrm{CH}$ & Midden L1 & $\begin{array}{l}\text { Saltonstall \& } \\
\text { Carver } 2002\end{array}$ \\
\hline AFG 015 & $\begin{array}{l}\text { Settlement } \\
\text { Point }\end{array}$ & Beta-101913 & 390 & 50 & $\mathrm{CH}$ & $\begin{array}{l}\text { Midden L2D/ } \\
\text { L2E contact }\end{array}$ & $\begin{array}{l}\text { Saltonstall \& } \\
\text { Carver } 2002\end{array}$ \\
\hline AFG 015 & $\begin{array}{l}\text { Settlement } \\
\text { Point }\end{array}$ & Beta-101912 & 440 & 50 & $\mathrm{CH}$ & $\begin{array}{l}\text { Midden bottom } \\
\text { L2 }\end{array}$ & $\begin{array}{l}\text { Saltonstall \& } \\
\text { Carver } 2002\end{array}$ \\
\hline AFG 015 & $\begin{array}{l}\text { Settlement } \\
\text { Point }\end{array}$ & Beta-114202 & 440 & 60 & $\mathrm{CH}$ & House 5 hearth & $\begin{array}{l}\text { Saltonstall \& } \\
\text { Carver } 2002\end{array}$ \\
\hline AFG 015 & $\begin{array}{l}\text { Settlement } \\
\text { Point }\end{array}$ & Beta-114204 & 450 & 50 & $\mathrm{CH}$ & House 7 hearth & $\begin{array}{l}\text { Saltonstall \& } \\
\text { Carver } 2002\end{array}$ \\
\hline AFG 015 & $\begin{array}{l}\text { Settlement } \\
\text { Point }\end{array}$ & Beta-118300 & 570 & 60 & $\mathrm{CH}$ & House 1 floor & $\begin{array}{l}\text { Saltonstall \& } \\
\text { Carver } 2002\end{array}$ \\
\hline AFG 015 & $\begin{array}{l}\text { Settlement } \\
\text { Point }\end{array}$ & Beta-101551 & 620 & 50 & $\mathrm{CH}$ & House 1 hearth & $\begin{array}{l}\text { Saltonstall \& } \\
\text { Carver } 2002\end{array}$ \\
\hline AFG 088 & Afognak River & Beta- 88720 & 2780 & 110 & $\mathrm{CH}$ & $\begin{array}{l}\text { intrusive fea- } \\
\text { ture, base of site }\end{array}$ & Clark 1997 \\
\hline AFG 088 & Afognak River & Beta-88719 & 3490 & 90 & $\mathrm{CH}$ & base of site & Clark 1997 \\
\hline AFG 088 & Afognak River & Beta-77807 & 3530 & 80 & $\mathrm{CH}$ & base of site & Clark 1997 \\
\hline AFG 215 & Tsunami & Beta-165141 & 880 & 40 & $\mathrm{CM}$ & $\begin{array}{l}\text { above tsunami } \\
\text { deposit in cul- } \\
\text { tural material }\end{array}$ & $\begin{array}{l}\text { D Clark, p.c. to } \\
\text { Fitzhugh } 2003\end{array}$ \\
\hline AFG 215 & Tsunami & Beta-165139 & 1320 & 80 & $\mathrm{CM}$ & $\begin{array}{l}\text { termination of } \\
\text { main house just } \\
\text { below tsunami } \\
\text { deposit }\end{array}$ & $\begin{array}{l}\text { D Clark, p.c. to } \\
\text { Fitzhugh } 2003\end{array}$ \\
\hline
\end{tabular}


Appendix B Late Holocene ${ }^{14} \mathrm{C}$ ages from prehistoric coastal archaeological sites at the Alaska subduction zone. (Continued)

\begin{tabular}{|c|c|c|c|c|c|c|c|}
\hline $\begin{array}{l}\text { AHRS nr } \\
(49-)\end{array}$ & Site name & Lab nr & $\begin{array}{l}{ }^{14} \mathrm{C} \\
\text { age }\end{array}$ & $\begin{array}{l}1-\sigma \\
\text { error }\end{array}$ & $\begin{array}{l}\text { Material } \\
\text { dated }^{\mathrm{a}}\end{array}$ & Context & Reference \\
\hline AFG 215 & Tsunami & Beta- 165140 & 1750 & 60 & $\mathrm{CM}$ & $\begin{array}{l}\text { from orange } \\
\text { clay floor of } \\
\text { house, should } \\
\text { just postdate be- } \\
\text { ginning of occu- } \\
\text { pation }\end{array}$ & $\begin{array}{l}\text { D Clark, p.c. to } \\
\text { Fitzhugh } 2003\end{array}$ \\
\hline KOD 026 & Monashka Bay & P-1049 & 298 & 44 & $\mathrm{CH}$ & riverine site & $\begin{array}{l}\text { Clark 1966a,b; } \\
\text { Mills } 1994\end{array}$ \\
\hline KOD 026 & Monashka Bay & Beta-33545 & 1570 & 60 & $\mathrm{CH}$ lens & from fire pit & $\begin{array}{l}\text { C Donta, p.c. } \\
1992 \text { to Mills } \\
1994\end{array}$ \\
\hline KOD 026 & Monashka Bay & Beta-34832 & 1680 & 50 & $\mathrm{CH}$ lens & midden sample & $\begin{array}{l}\text { C Donta, p.c. } \\
1992 \text { to Mills } \\
1994\end{array}$ \\
\hline KOD 043 & Kizhuyak & B-836 & 600 & 100 & $\mathrm{CH}$ & & $\begin{array}{l}\text { Clark 1984; } \\
\text { Mills } 1994\end{array}$ \\
\hline KOD 044 & Crag Pt. & Beta-20122 & 910 & 60 & $\mathrm{CH}$ & & $\begin{array}{l}\text { Haggarty et al. } \\
\text { 1991; Mills } 1994\end{array}$ \\
\hline KOD 044 & Crag Pt. & Beta-45944 & 910 & 70 & $\mathrm{CH}$ & & Mills 1994 \\
\hline KOD 044 & Crag Pt. & Beta-20533 & 1890 & 90 & $\mathrm{CH}$ & & $\begin{array}{l}\text { Haggarty et al. } \\
\text { 1991; Mills } 1994\end{array}$ \\
\hline KOD 044 & Crag Pt. & Beta-92094 & 1940 & 60 & WD & & $\begin{array}{l}\text { D Clark, p.c. to } \\
\text { Fitzhugh } 2003\end{array}$ \\
\hline KOD 044 & Crag Pt. & Beta-48044 & 2000 & 70 & $\mathrm{CH}$ & & Mills 1994 \\
\hline KOD 044 & Crag Pt. & P-1057 & 2033 & 52 & $\mathrm{CH}$ & $\begin{array}{l}\text { approx. basal } \\
\text { date from main } \\
\text { component }\end{array}$ & $\begin{array}{l}\text { D Clark, p.c. to } \\
\text { Fitzhugh } 2003\end{array}$ \\
\hline KOD 044 & Crag Pt. & Beta-48043 & 2190 & 90 & $?$ & & Mills 1994 \\
\hline KOD 044 & Crag Pt. & Beta-45943 & 2380 & 70 & $\mathrm{CH}$ & & Mills 1994 \\
\hline KOD 044 & Crag Pt. & Beta-94894 & 3150 & 80 & $\mathrm{BO}$ & $\begin{array}{l}\text { dark thick lower } \\
\text { stony black } \\
\text { Kachemak layer }\end{array}$ & $\begin{array}{l}\text { D Clark, p.c. to } \\
\text { Fitzhugh } 2003\end{array}$ \\
\hline KOD 044 & Crag Pt. & Beta-45942 & 3160 & 70 & $\mathrm{CH}$ & & Mills 1994 \\
\hline KOD 044 & Crag Pt. & Beta-66656 & 3190 & 50 & $\mathrm{CH}$ & & Mills 1994 \\
\hline KOD 044 & Crag Pt. & Beta-66655 & 3290 & 50 & $\mathrm{CH}$ & & Mills 1994 \\
\hline KOD 044 & Crag Pt. & Beta-45945 & 3340 & 60 & $\mathrm{CH}$ & & Mills 1994 \\
\hline KOD 083 & Three Saints & P-1042 & 2028 & 55 & $\mathrm{CH}$ & $\begin{array}{l}\text { associated with } \\
\text { hearth and clay- } \\
\text { lined basin }\end{array}$ & $\begin{array}{l}\text { Clark 1966a; } \\
\text { Mills } 1994\end{array}$ \\
\hline KOD 099 & $\begin{array}{l}\text { Kiavak (Naum- } \\
\text { liak, Nayum- } \\
\text { lyak, Kiyaik) }\end{array}$ & P-1044 & 280 & 44 & $\mathrm{CH}$ & $\begin{array}{l}\text { basal level in } \\
\text { rubble lens }\end{array}$ & $\begin{array}{l}\text { Clark 1966a; } \\
\text { Mills } 1994\end{array}$ \\
\hline KOD 099 & $\begin{array}{l}\text { Kiavak (Naum- } \\
\text { liak, Nayum- } \\
\text { lyak, Kiyaik) }\end{array}$ & P-1045 & 391 & 48 & $\mathrm{CH}$ & refuse lens & $\begin{array}{l}\text { Clark 1966a; } \\
\text { Mills } 1994\end{array}$ \\
\hline KOD 100 & Kiavak & S-2996 & 1960 & 75 & $\mathrm{CH}$ & $\begin{array}{l}\text { housepit, pene- } \\
\text { trates to near } \\
\text { base }\end{array}$ & Clark 1997 \\
\hline KOD 100 & Kiavak & S-3488 & 2750 & 130 & $\mathrm{CH}$ & $\begin{array}{l}\text { bulk sample } \\
\text { collected from } \\
\text { over } 40 \text { vertical } \\
\text { cm; may mix } \\
\text { charcoal, shell, } \\
\text { bone, and oil }\end{array}$ & Clark 1997 \\
\hline KOD 100 & Kiavak & P-1039 & 3263 & 71 & $\mathrm{CH}$ & $\begin{array}{l}\text { midden, middle } \\
\text { component }\end{array}$ & Clark 1974 \\
\hline
\end{tabular}


Appendix B Late Holocene ${ }^{14} \mathrm{C}$ ages from prehistoric coastal archaeological sites at the Alaska subduction zone. (Continued)

\begin{tabular}{|c|c|c|c|c|c|c|c|}
\hline $\begin{array}{l}\text { AHRS nr } \\
(49-)\end{array}$ & Site name & Lab nr & $\begin{array}{l}{ }^{14} \mathrm{C} \\
\text { age }\end{array}$ & $\begin{array}{l}1-\sigma \\
\text { error }\end{array}$ & $\begin{array}{l}\text { Material } \\
\text { dated }^{\mathrm{a}}\end{array}$ & Context & Reference \\
\hline KOD 101 & Rolling Bay & P-1048 & 353 & 44 & $\mathrm{CH}$ & $\begin{array}{l}\text { exterior hearth; } \\
\text { base of deposit }\end{array}$ & $\begin{array}{l}\text { Clark 1966b; } \\
\text { Mills } 1994\end{array}$ \\
\hline KOD 101 & Rolling Bay & P-1047 & 393 & 40 & $\mathrm{CH}$ & $\begin{array}{l}\text { exterior hearth; } \\
\text { base of deposit }\end{array}$ & $\begin{array}{l}\text { Clark 1966b; } \\
\text { Mills } 1994\end{array}$ \\
\hline KOD 106 & SAS 126 & Beta-78518 & 930 & 70 & $\mathrm{CH}$ & & Fitzhugh 2003 \\
\hline KOD 110 & SAS 25 & Beta-78502 & 480 & 60 & $\mathrm{CH}$ & & Fitzhugh 2003 \\
\hline KOD 210 & Blisky & Beta-77806 & 340 & 70 & WD/CH & $\begin{array}{l}\text { fire pit, burned } \\
\text { log, may be part } \\
\text { of sweat bath } \\
\text { feature; should } \\
\text { be older than } \\
\text { sweat bath due } \\
\text { to old-wood } \\
\text { problem }\end{array}$ & $\begin{array}{l}\text { D Clark, p.c. to } \\
\text { Fitzhugh } 2003\end{array}$ \\
\hline KOD 210 & Blisky & Beta-77805 & 410 & 80 & GR & $\begin{array}{l}\text { in sweat bath } \\
\text { feature; should } \\
\text { be accurate age } \\
\text { of bath }\end{array}$ & $\begin{array}{l}\text { D Clark, p.c. to } \\
\text { Fitzhugh } 2003\end{array}$ \\
\hline KOD 210 & Blisky & Beta-77804 & 2010 & 80 & & $\begin{array}{l}\text { hearth, base of } \\
\text { site, test pit }\end{array}$ & $\begin{array}{l}\text { D Clark, p.c. to } \\
\text { Fitzhugh } 2003\end{array}$ \\
\hline KOD 210 & Blisky & Beta-113164 & 2880 & 120 & $\mathrm{CH}$ & $\begin{array}{l}\text { from discrete } \\
\text { lens in house } \\
\text { floor }\end{array}$ & $\begin{array}{l}\text { Steffian, p.c. to } \\
\text { Fitzhugh } 2003\end{array}$ \\
\hline KOD 210 & Blisky & Beta-113163 & 3050 & 60 & $\mathrm{CH}$ & from FCR dump & $\begin{array}{l}\text { Steffian, p.c. to } \\
\text { Fitzhugh } 2003\end{array}$ \\
\hline KOD 324 & Kizhuyak Bay & Beta-14497 & 2700 & 90 & $\mathrm{CH}$ & $\begin{array}{l}\text { charcoal lens in } \\
\text { midden }\end{array}$ & $\begin{array}{l}\text { Crozier 1989; } \\
\text { Mills } 1994\end{array}$ \\
\hline KOD 324 & Kizhuyak Bay & Beta-8186 & 3520 & 60 & $\mathrm{CH}$ & $\begin{array}{l}\text { from erosion } \\
\text { profile }\end{array}$ & Mills 1994 \\
\hline KOD 324 & Kizhuyak Bay & Beta- 14500 & 3630 & 80 & $\mathrm{CH}$ & $\begin{array}{l}\text { from test pit- } \\
\text { no other info }\end{array}$ & Mills 1994 \\
\hline KOD 504 & SAS 48 & Beta-78503 & 360 & 60 & $\mathrm{CH}$ & & Fitzhugh 2003 \\
\hline KOD 509 & SAS 54 & Beta-78505 & 820 & 90 & $\mathrm{CH}$ & & Fitzhugh 2003 \\
\hline KOD 510 & SAS 55 & Beta-78521 & 400 & 50 & $\mathrm{CH}$ & & Fitzhugh 2003 \\
\hline KOD 516 & SAS 62 & Beta-78506 & 1720 & 60 & $\mathrm{CH}$ & & Fitzhugh 2003 \\
\hline KOD 540 & SAS 100 & Beta-78511 & 1500 & 60 & $\mathrm{CH}$ & & Fitzhugh 2003 \\
\hline KOD 541 & SAS 101 & Beta-78512 & 1530 & 60 & $\mathrm{CH}$ & & Fitzhugh 2003 \\
\hline KOD 552 & SAS 117 & Beta-78514 & 1090 & 60 & $\mathrm{CH}$ & & Fitzhugh 2003 \\
\hline KOD 564 & SAS 49 & Beta-71092 & 1750 & 60 & $\mathrm{CH}$ & & Fitzhugh 2003 \\
\hline KOD 564 & SAS 49 & Beta-91316 & 1890 & 70 & $\mathrm{CH}$ & & Fitzhugh 2003 \\
\hline KOD 566 & SAS 86 & Beta-78510 & 1610 & 60 & $\mathrm{CH}$ & & Fitzhugh 2003 \\
\hline KOD 578 & SAS 143 & Beta-91318 & 2110 & 50 & $\mathrm{CH}$ & & Fitzhugh 2003 \\
\hline XTI 052 & Sitkinak & Beta-7325 & 200 & 50 & $?$ & $?$ & $\begin{array}{l}\text { Haggarty et al. } \\
\text { 1991; Mills } 1994\end{array}$ \\
\hline XTI 052 & Sitkinak & Beta-7326 & 750 & 80 & $?$ & $?$ & $\begin{array}{l}\text { Haggarty et al. } \\
\text { 1991; Mills } 1994\end{array}$ \\
\hline \multicolumn{8}{|c|}{ "Inner coast" } \\
\hline AFG 082 & Shuyak I. & GX-17333 & 1730 & 65 & $\mathrm{CH}$ & lower midden & Reger et al. 1992 \\
\hline AFG 082 & Shuyak I. & GX-17334 & 1840 & 65 & $\mathrm{CH}$ & lower midden & Reger et al. 1992 \\
\hline AFG 098 & $\begin{array}{l}\text { Neketa Bay, } \\
\text { Shuyak I. }\end{array}$ & GX-17332 & 360 & 125 & $\begin{array}{l}\text { spruce } \\
\text { bark }\end{array}$ & $\begin{array}{l}\text { upper compo- } \\
\text { nent }\end{array}$ & Reger et al. 1992 \\
\hline AFG 098 & $\begin{array}{l}\text { Neketa Bay, } \\
\text { Shuyak I. }\end{array}$ & GX-17323 & 500 & 60 & $\begin{array}{l}\text { bark } \\
\text { (spruce?) }\end{array}$ & $\begin{array}{l}\text { upper compo- } \\
\text { nent }\end{array}$ & Reger et al. 1992 \\
\hline AFG 098 & $\begin{array}{l}\text { Neketa Bay, } \\
\text { Shuyak I. }\end{array}$ & GX-17326 & 500 & 100 & $\mathrm{CH}$ & $\begin{array}{l}\text { upper compo- } \\
\text { nent }\end{array}$ & Reger et al. 1992 \\
\hline
\end{tabular}


Appendix B Late Holocene ${ }^{14} \mathrm{C}$ ages from prehistoric coastal archaeological sites at the Alaska subduction zone. (Continued)

\begin{tabular}{|c|c|c|c|c|c|c|c|}
\hline $\begin{array}{l}\text { AHRS nr } \\
(49-)\end{array}$ & Site name & Lab nr & $\begin{array}{l}{ }^{14} \mathrm{C} \\
\text { age }\end{array}$ & $\begin{array}{l}1-\sigma \\
\text { error }\end{array}$ & $\begin{array}{l}\text { Material } \\
\text { dated }^{\mathrm{a}}\end{array}$ & Context & Reference \\
\hline AFG 098 & $\begin{array}{l}\text { Neketa Bay, } \\
\text { Shuyak I. }\end{array}$ & GX-17325 & 500 & 105 & $\mathrm{CH}$ & $\begin{array}{l}\text { upper compo- } \\
\text { nent }\end{array}$ & Reger et al. 1992 \\
\hline AFG 098 & $\begin{array}{l}\text { Neketa Bay, } \\
\text { Shuyak I. }\end{array}$ & GX-17331 & 570 & 60 & $\mathrm{CH}$ & $\begin{array}{l}\text { upper compo- } \\
\text { nent }\end{array}$ & Reger et al. 1992 \\
\hline AFG 098 & $\begin{array}{l}\text { Neketa Bay, } \\
\text { Shuyak I. }\end{array}$ & GX-17328 & 625 & 60 & $\mathrm{CH}$ & $\begin{array}{l}\text { upper compo- } \\
\text { nent }\end{array}$ & Reger et al. 1992 \\
\hline AFG 098 & $\begin{array}{l}\text { Neketa Bay, } \\
\text { Shuyak I. }\end{array}$ & GX-17327 & 950 & 65 & $\begin{array}{l}\text { grass, } \\
\text { needles }\end{array}$ & $\begin{array}{l}\text { lower compo- } \\
\text { nent }\end{array}$ & Reger et al. 1992 \\
\hline AFG 098 & $\begin{array}{l}\text { Neketa Bay, } \\
\text { Shuyak I. }\end{array}$ & GX-17329 & 1040 & 105 & $\mathrm{CH}$ & $\begin{array}{l}\text { lower compo- } \\
\text { nent }\end{array}$ & Reger et al. 1992 \\
\hline AFG 098 & $\begin{array}{l}\text { Neketa Bay, } \\
\text { Shuyak I. }\end{array}$ & GX-17324 & 1055 & 105 & $\mathrm{CH}$ & $\begin{array}{l}\text { lower compo- } \\
\text { nent }\end{array}$ & Reger et al. 1992 \\
\hline AFG 098 & $\begin{array}{l}\text { Neketa Bay, } \\
\text { Shuyak I. }\end{array}$ & GX-17330 & 1175 & 110 & $\mathrm{CH}$ & $\begin{array}{l}\text { lower compo- } \\
\text { nent }\end{array}$ & Reger et al. 1992 \\
\hline AFG 119 & - & Beta-42074 & 1000 & 80 & $?$ & & $\begin{array}{l}\text { Haggarty et al. } \\
\text { 1991; Mills } 1994\end{array}$ \\
\hline AFG 207 & $\begin{array}{l}\text { Sukoi Bay ter- } \\
\text { race }\end{array}$ & Beta-74849 & 2020 & 80 & $\mathrm{CH}$ & $\begin{array}{l}\text { upper compo- } \\
\text { nent }\end{array}$ & $\begin{array}{l}\text { Crowell \& Mann } \\
1996\end{array}$ \\
\hline AFG 207 & $\begin{array}{l}\text { Sukoi Bay ter- } \\
\text { race }\end{array}$ & Beta-74850 & 3570 & 60 & $\mathrm{CH}$ & $\begin{array}{l}\text { lower compo- } \\
\text { nent }\end{array}$ & $\begin{array}{l}\text { Crowell \& Mann } \\
1996\end{array}$ \\
\hline KAR 001 & New Karluk & Beta-15014 & 290 & 60 & WD & $\begin{array}{l}\text { HF } 6 \text { (floor- } \\
\text { plank) }\end{array}$ & $\begin{array}{l}\text { Jordan \& Knecht } \\
\text { 1988; Mills } 1994\end{array}$ \\
\hline KAR 001 & New Karluk & Beta-8942 & 370 & 50 & $\mathrm{CH}$ & $\begin{array}{l}\text { from erosion } \\
\text { profile/ TP }\end{array}$ & Mills 1994 \\
\hline KAR 001 & New Karluk & Beta- 15015 & 480 & 80 & WD & $\begin{array}{l}\text { HF } 8 \text { (floor- } \\
\text { plank) }\end{array}$ & $\begin{array}{l}\text { Jordan \& Knecht } \\
\text { 1988; Mills } 1994\end{array}$ \\
\hline KAR 001 & New Karluk & Beta-25599 & 630 & 50 & WD & $\begin{array}{l}\text { HF 9A (floor- } \\
\text { plank) }\end{array}$ & unpublished \\
\hline KAR 001 & New Karluk & Beta-15016 & 740 & 80 & WD & $\begin{array}{l}\text { HF } 10 \text { (floor- } \\
\text { plank) }\end{array}$ & $\begin{array}{l}\text { Jordan \& Knecht } \\
\text { 1988; Mills } 1994\end{array}$ \\
\hline KAR 001 & New Karluk & Beta-25600 & 780 & 60 & WD & $?$ & Mills 1994 \\
\hline KAR 029 & Larsen Bay & Beta-23767 & 450 & 70 & carbon & $\begin{array}{l}\text { structural de- } \\
\text { pression }\end{array}$ & $\begin{array}{l}\text { Crozier 1989; } \\
\text { Mills } 1994\end{array}$ \\
\hline KAR 029 & Larsen Bay & Beta-23769 & 620 & 50 & carbon & house floor & $\begin{array}{l}\text { Crozier 1989; } \\
\text { Mills } 1994\end{array}$ \\
\hline KAR 029 & Larsen Bay & Beta-23768 & 870 & 70 & $\mathrm{CH}$ & hearth & $\begin{array}{l}\text { Crozier 1989; } \\
\text { Mills } 1994\end{array}$ \\
\hline KAR 029 & Larsen Bay & Beta-23765 & 990 & 60 & $\mathrm{CH}$ & $\begin{array}{l}\text { fire pit assoc. w/ } \\
\text { house floor }\end{array}$ & $\begin{array}{l}\text { Crozier 1989; } \\
\text { Mills } 1994\end{array}$ \\
\hline KAR 029 & Larsen Bay & Beta-23766 & 1000 & 110 & $\mathrm{CH}$ & $\begin{array}{l}\text { fire pit assoc. w/ } \\
\text { house floor }\end{array}$ & $\begin{array}{l}\text { Crozier 1989; } \\
\text { Mills } 1994\end{array}$ \\
\hline KAR 029 & Larsen Bay & Beta-23771 & 1290 & 80 & $\mathrm{CH}$ & $\begin{array}{l}\text { hearth in house } \\
\text { floor }\end{array}$ & $\begin{array}{l}\text { Crozier 1989; } \\
\text { Mills } 1994\end{array}$ \\
\hline KAR 029 & Larsen Bay & Beta-23770 & 1310 & 70 & carbon & house floor & $\begin{array}{l}\text { Crozier 1989; } \\
\text { Mills } 1994\end{array}$ \\
\hline KAR 031 & Old Karluk & Beta-15017 & 320 & 60 & $\mathrm{CH}$ & $\begin{array}{l}\text { exterior hearth; } \\
\text { Level 3, midden }\end{array}$ & $\begin{array}{l}\text { Mills 1994; re- } \\
\text { jected by Jordan, } \\
\text { accepted by } \\
\text { Mills } 1994\end{array}$ \\
\hline KAR 031 & Old Karluk & Beta- 15690 & 430 & 60 & $\mathrm{CH}$ & $\begin{array}{l}\text { midden, L-3, } \\
\text { Feature B }\end{array}$ & $\begin{array}{l}\text { Mills 1994; re- } \\
\text { jected by Jordan, } \\
\text { accepted by } \\
\text { Mills } 1994\end{array}$ \\
\hline KAR 031 & Old Karluk & Beta-15691 & 980 & 60 & WD & $\begin{array}{l}\text { L-7, house floor } \\
\text { plank }\end{array}$ & $\begin{array}{l}\text { Jordan 1992; } \\
\text { Mills } 1994\end{array}$ \\
\hline
\end{tabular}


Appendix B Late Holocene ${ }^{14} \mathrm{C}$ ages from prehistoric coastal archaeological sites at the Alaska subduction zone. (Continued)

\begin{tabular}{|c|c|c|c|c|c|c|c|}
\hline $\begin{array}{l}\text { AHRS nr } \\
(49-)\end{array}$ & Site name & Lab nr & $\begin{array}{l}{ }^{14} \mathrm{C} \\
\text { age }\end{array}$ & $\begin{array}{l}1-\sigma \\
\text { error }\end{array}$ & $\begin{array}{l}\text { Material } \\
\text { dated }^{\mathrm{a}}\end{array}$ & Context & Reference \\
\hline KAR 031 & Old Karluk & Beta-8946 & 2010 & 70 & WD & $\begin{array}{l}\text { post from L-7 } \\
\text { house floor }\end{array}$ & $\begin{array}{l}\text { Jordan \& Knecht } \\
\text { 1988; Mills } 1994\end{array}$ \\
\hline KAR 031 & Old Karluk & Beta-8945 & 2540 & 60 & $\mathrm{CH}$ & L-9 & $\begin{array}{l}\text { Jordan \& Knecht } \\
\text { 1988; Mills } 1994\end{array}$ \\
\hline KAR 039 & & Beta-8943 & 2650 & 60 & $\mathrm{CH}$ & $\mathrm{TP}$ & $\begin{array}{l}\text { Haggarty et al. } \\
\text { 1991; Mills } 1994\end{array}$ \\
\hline KAR 048 & & Beta-8944 & 3050 & 70 & $\mathrm{CH}$ & pit feature? & Mills 1994 \\
\hline KOD 145 & Uyak & Beta-34281 & 1130 & 70 & $\mathrm{CH}$ & hearth in House & $\begin{array}{l}\text { Steffian 1992; } \\
\text { Mills } 1994\end{array}$ \\
\hline KOD 145 & Uyak & Beta-25603 & 1140 & 90 & WD & $\begin{array}{l}\text { House } 13 \text { floor- } \\
\text { plank }\end{array}$ & $\begin{array}{l}\text { Steffian 1992; } \\
\text { Mills } 1994\end{array}$ \\
\hline KOD 145 & Uyak & Beta-34283 & 1270 & 100 & $\mathrm{CH}$ & hearth in House & $\begin{array}{l}\text { Steffian 1992; } \\
\text { Mills } 1994\end{array}$ \\
\hline KOD 145 & Uyak & Beta-25602 & 1310 & 70 & $\mathrm{CH}$ & $\begin{array}{l}\text { hearth in House } \\
8\end{array}$ & $\begin{array}{l}\text { Steffian 1992; } \\
\text { Mills } 1994\end{array}$ \\
\hline KOD 145 & Uyak & Beta-34282 & 1320 & 70 & WD & $\begin{array}{l}\text { outer rings from } \\
\text { post in House } 1\end{array}$ & $\begin{array}{l}\text { Steffian 1992; } \\
\text { Mills } 1994\end{array}$ \\
\hline KOD 224 & Uganik I. & UGa-2823 & 1080 & 90 & $?$ & $?$ & $\begin{array}{l}\text { Haggarty et al. } \\
\text { 1991; Mills } 1994\end{array}$ \\
\hline KOD 224 & Uganik I. & UGa-2820 & 3130 & 85 & $?$ & $?$ & $\begin{array}{l}\text { Clark 1984; } \\
\text { Mills } 1994\end{array}$ \\
\hline KOD 224 & Uganik I. & UGa-2822 & 3365 & 70 & $?$ & $?$ & $\begin{array}{l}\text { Clark 1984; } \\
\text { Mills } 1994\end{array}$ \\
\hline XMK 006 & Kukak & Beta-97002 & 720 & 70 & $\mathrm{CH}$ & House 3 & $\begin{array}{l}\text { D Dumond, p.c. } \\
2002\end{array}$ \\
\hline XMK 006 & Kukak & I-1636 & 775 & 110 & $\mathrm{CH}$ & House & $\begin{array}{l}\text { Clark 1977; } \\
\text { Mills 1994; } \\
\text { Crowell \& Mann } \\
1996\end{array}$ \\
\hline XMK 006 & Kukak & $\mathrm{I}-505$ & 775 & 95 & $\mathrm{CH}$ & & $\begin{array}{l}\text { Mills 1994; } \\
\text { Crowell \& Mann } \\
1996\end{array}$ \\
\hline XMK 006 & Kukak & I-1638 & 1075 & 100 & $\mathrm{CH}$ & floor & $\begin{array}{l}\text { Clark 1977; } \\
\text { Mills 1994; } \\
\text { Crowell \& Mann } \\
1996\end{array}$ \\
\hline XMK 006 & Kukak & $\mathrm{I}-1637$ & 1450 & 130 & $\mathrm{CH}$ & floor & $\begin{array}{l}\text { Clark 1977; } \\
\text { Mills 1994; } \\
\text { Crowell \& Mann } \\
1996\end{array}$ \\
\hline XMK 006 & Kukak & I-1944 & 1460 & 95 & $\mathrm{CH}$ & floor & $\begin{array}{l}\text { Clark 1977; } \\
\text { Mills 1994; } \\
\text { Crowell \& Mann } \\
1996\end{array}$ \\
\hline XMK 018 & Takli & I-3733 & 2810 & 100 & $\mathrm{CH}$ & & $\begin{array}{l}\text { Clark 1977; } \\
\text { Mills 1994; } \\
\text { Crowell \& Mann } \\
1996\end{array}$ \\
\hline XMK 018 & Takli & I-1941 & 2910 & 105 & $\mathrm{CH}$ & & $\begin{array}{l}\text { Clark 1977; } \\
\text { Mills 1994; } \\
\text { Crowell \& Mann } \\
1998\end{array}$ \\
\hline XMK 020 & Hook Point & I-1942 & 1680 & 100 & $\mathrm{CH}$ & floor & $\begin{array}{l}\text { Clark 1977; } \\
\text { Mills 1994; } \\
\text { Crowell \& Mann } \\
1996\end{array}$ \\
\hline
\end{tabular}


Appendix B Late Holocene ${ }^{14} \mathrm{C}$ ages from prehistoric coastal archaeological sites at the Alaska subduction zone. (Continued)

\begin{tabular}{|c|c|c|c|c|c|c|c|}
\hline $\begin{array}{l}\text { AHRS nr } \\
(49-)\end{array}$ & Site name & Lab nr & $\begin{array}{l}{ }^{14} \mathrm{C} \\
\text { age }\end{array}$ & $\begin{array}{l}1-\sigma \\
\text { error }\end{array}$ & $\begin{array}{l}\text { Material } \\
\text { dated }^{\mathrm{a}}\end{array}$ & Context & Reference \\
\hline XMK 020 & Hook Point & I-1943 & 3470 & 110 & $\mathrm{CH}$ & hearth & $\begin{array}{l}\text { Clark 1977; } \\
\text { Mills 1994; } \\
\text { Crowell \& Mann } \\
1997\end{array}$ \\
\hline XMK 030 & Mink Island & Beta-122729 & 370 & 40 & $\mathrm{CH}$ & upper midden & unpublished \\
\hline XMK 030 & Mink Island & Beta-130090 & 400 & 60 & $\mathrm{CH}$ & upper midden & unpublished \\
\hline XMK 030 & Mink Island & Beta-149293 & 520 & 80 & $\mathrm{CH}$ & upper midden & unpublished \\
\hline XMK 030 & Mink Island & Beta-109926 & 540 & 60 & $\mathrm{CH}$ & upper midden & unpublished \\
\hline XMK 030 & Mink Island & Beta-130091 & 720 & 60 & $\mathrm{CH}$ & upper midden & unpublished \\
\hline XMK 030 & Mink Island & Beta-109929 & 850 & 60 & $\mathrm{CH}$ & upper midden & unpublished \\
\hline XMK 030 & Mink Island & Beta-109927 & 860 & 50 & $\mathrm{CH}$ & upper midden & unpublished \\
\hline XMK 030 & Mink Island & Beta-109928 & 860 & 140 & $\mathrm{CH}$ & upper midden & unpublished \\
\hline XMK 030 & Mink Island & Beta- 114541 & 950 & 60 & $\mathrm{CH}$ & upper midden & unpublished \\
\hline XMK 030 & Mink Island & Beta-115542 & 970 & 50 & $\mathrm{CH}$ & upper midden & unpublished \\
\hline XMK 030 & Mink Island & Beta-109930 & 970 & 60 & $\mathrm{CH}$ & upper midden & unpublished \\
\hline XMK 030 & Mink Island & Beta-114544 & 1510 & 90 & $\mathrm{CH}$ & upper midden & unpublished \\
\hline XMK 030 & Mink Island & Beta-147721 & 1590 & 40 & $\mathrm{CH}$ & upper midden & unpublished \\
\hline XMK 030 & Mink Island & Beta-109931 & 1620 & 60 & $\mathrm{CH}$ & upper midden & unpublished \\
\hline XMK 030 & Mink Island & Beta-130085 & 1650 & 70 & $\mathrm{CH}$ & upper midden & unpublished \\
\hline XMK 030 & Mink Island & Beta-114545 & 1710 & 50 & $\mathrm{CH}$ & upper midden & unpublished \\
\hline XMK 030 & Mink Island & Beta-114543 & 1920 & 120 & $\mathrm{CH}$ & upper midden & unpublished \\
\hline XMK 030 & Mink Island & WSU-5044 & 1925 & 50 & $\mathrm{CH}$ & upper midden & unpublished \\
\hline XMK 030 & Mink Island & Beta-130086 & 2010 & 60 & $\mathrm{CH}$ & upper midden & unpublished \\
\hline XMK 030 & Mink Island & Beta-130102 & 3690 & 130 & $\mathrm{CH}$ & lower midden & unpublished \\
\hline XMK 047 & $\begin{array}{l}\text { Russian An- } \\
\text { chorage }\end{array}$ & Beta-75314 & 640 & 90 & $\mathrm{CH}$ & & $\begin{array}{l}\text { Crowell \& Mann } \\
1996\end{array}$ \\
\hline XMK 056 & $\begin{array}{l}\text { Russian An- } \\
\text { chorage }\end{array}$ & Beta-74853 & 690 & 60 & $\mathrm{CH}$ & & $\begin{array}{l}\text { Crowell \& Mann } \\
1996\end{array}$ \\
\hline XMK 056 & $\begin{array}{l}\text { Russian An- } \\
\text { chorage }\end{array}$ & Beta-75318 & 1890 & 70 & $\mathrm{CH}$ & & $\begin{array}{l}\text { Crowell \& Mann } \\
1996\end{array}$ \\
\hline XMK 058 & Cape Gull & GX-17008 & 510 & 105 & $\mathrm{CH}$ & $\begin{array}{l}\text { split w/ GX- } \\
17009\end{array}$ & $\begin{array}{l}\text { Haggarty et al. } \\
\text { 1991; Dekin et } \\
\text { al. } 1993\end{array}$ \\
\hline XMK 058 & Cape Gull & GX-17009 & 550 & 85 & $\mathrm{CH}$ & $\begin{array}{l}\text { split w/ GX- } \\
17008\end{array}$ & $\begin{array}{l}\text { Haggarty et al. } \\
\text { 1991; Dekin et } \\
\text { al. } 1993\end{array}$ \\
\hline XMK 058 & Cape Gull & $\begin{array}{l}\text { wt. mean \& sd } \\
\text { GX-17006 }\end{array}$ & $\begin{array}{l}534 \\
525\end{array}$ & $\begin{array}{l}66 \\
60\end{array}$ & $\mathrm{CH}$ & $\begin{array}{l}\text { split w/ GX- } \\
17007\end{array}$ & $\begin{array}{l}\text { Haggarty et al. } \\
\text { 1991; Dekin et } \\
\text { al. } 1993\end{array}$ \\
\hline XMK 058 & Cape Gull & GX-17007 & 590 & 105 & $\mathrm{CH}$ & $\begin{array}{l}\text { split w/ GX- } \\
17006\end{array}$ & $\begin{array}{l}\text { Haggarty et al. } \\
\text { 1991; Dekin et } \\
\text { al. } 1993\end{array}$ \\
\hline XMK 058 & Cape Gull & $\begin{array}{l}\text { wt. mean \& sd } \\
\text { GX-17005 }\end{array}$ & $\begin{array}{l}541 \\
730\end{array}$ & $\begin{array}{r}52 \\
120\end{array}$ & $\mathrm{CH}$ & $\begin{array}{l}\text { split w/ GX- } \\
17004\end{array}$ & $\begin{array}{l}\text { Haggarty et al. } \\
\text { 1991; Dekin et } \\
\text { al. } 1993\end{array}$ \\
\hline XMK 058 & Cape Gull & GX-17004 & 750 & 110 & $\mathrm{CH}$ & $\begin{array}{l}\text { split w/ GX- } \\
17005\end{array}$ & $\begin{array}{l}\text { Haggarty et al. } \\
\text { 1991; Dekin et } \\
\text { al. } 1993\end{array}$ \\
\hline XMK 059 & $\begin{array}{l}\text { Kukak Bay } \\
\text { Refuge Rock }\end{array}$ & $\begin{array}{l}\text { wt. mean \& sd } \\
\text { Beta-74856 }\end{array}$ & $\begin{array}{l}741 \\
360\end{array}$ & $\begin{array}{l}81 \\
60\end{array}$ & $\mathrm{CH}$ & midden & $\begin{array}{l}\text { Crowell \& Mann } \\
1996\end{array}$ \\
\hline XMK 072 & Takli Islet & GX-17214 & 3605 & 150 & $\mathrm{CH}$ & $\begin{array}{l}\text { split w/ GX- } \\
\text { 17215; midden }\end{array}$ & $\begin{array}{l}\text { Dekin et al. } \\
\text { 1993; Crowell \& } \\
\text { Mann } 1996\end{array}$ \\
\hline
\end{tabular}


Appendix B Late Holocene ${ }^{14} \mathrm{C}$ ages from prehistoric coastal archaeological sites at the Alaska subduction zone. (Continued)

\begin{tabular}{|c|c|c|c|c|c|c|c|}
\hline $\begin{array}{l}\text { AHRS nr } \\
(49-)\end{array}$ & Site name & Lab nr & $\begin{array}{l}{ }^{14} \mathrm{C} \\
\text { age }\end{array}$ & $\begin{array}{l}1-\sigma \\
\text { error }\end{array}$ & $\begin{array}{l}\text { Material } \\
\text { dated }^{\mathrm{a}}\end{array}$ & Context & Reference \\
\hline XMK 072 & Takli Islet & GX-17215 & 3875 & 175 & $\mathrm{CH}$ & $\begin{array}{l}\text { split w/ GX- } \\
\text { 17214; midden }\end{array}$ & $\begin{array}{l}\text { Dekin et al. } \\
\text { 1993; Crowell \& } \\
\text { Mann } 1996\end{array}$ \\
\hline XMK 075 & Takli Island & $\begin{array}{l}\text { wt. mean \& sd } \\
\text { GX-17212 }\end{array}$ & $\begin{array}{l}3719 \\
2175\end{array}$ & $\begin{array}{l}113 \\
205\end{array}$ & $\mathrm{CH}$ & $\begin{array}{l}\text { split w/ GX- } \\
17213\end{array}$ & $\begin{array}{l}\text { Dekin et al. } \\
\text { 1993; Crowell \& } \\
\text { Mann } 1996\end{array}$ \\
\hline XMK 075 & Takli Island & GX-17213 & 2020 & 180 & $\mathrm{CH}$ & $\begin{array}{l}\text { split w/ GX- } \\
17212\end{array}$ & $\begin{array}{l}\text { Dekin et al. } \\
\text { 1993; Crowell \& } \\
\text { Mann } 1996\end{array}$ \\
\hline XMK 106 & $\begin{array}{l}\text { Tiny Island Vil- } \\
\text { lage }\end{array}$ & $\begin{array}{l}\text { wt. mean \& sd } \\
\text { Beta-74857 }\end{array}$ & $\begin{array}{l}2087 \\
1530\end{array}$ & $\begin{array}{r}135 \\
80\end{array}$ & $\mathrm{CH}$ & & $\begin{array}{l}\text { Crowell \& Mann } \\
1996\end{array}$ \\
\hline XMK 107 & Tiny Island II & Beta-83699 & 620 & 60 & $\mathrm{CH}$ & & $\begin{array}{l}\text { Crowell \& Mann } \\
1996\end{array}$ \\
\hline XMK 111 & $\begin{array}{l}\text { Tiny Island } \\
\text { Passage }\end{array}$ & Beta-75315 & 3270 & 70 & $\mathrm{CH}$ & & $\begin{array}{l}\text { Crowell \& Mann } \\
1996\end{array}$ \\
\hline XMK 113 & $\begin{array}{l}\text { Kinak River } \\
\text { Wet Site }\end{array}$ & Beta-74851 & 210 & 60 & $\mathrm{CH}$ & & \\
\hline XMK 113 & $\begin{array}{l}\text { Kinak River } \\
\text { Wet Site }\end{array}$ & Beta-74852 & 960 & 60 & $\mathrm{CH}$ & & \\
\hline XMK 115 & $\begin{array}{l}\text { Aguchik Island } \\
\text { Cove }\end{array}$ & Beta-74664 & 3560 & 80 & $\mathrm{CH}$ & $\begin{array}{l}\text { non-cultural } \\
\text { (RSL estimate } \\
\text { @ } 0.6 \mathrm{~m} \text { asl) }\end{array}$ & $\begin{array}{l}\text { Crowell \& Mann } \\
1996\end{array}$ \\
\hline XMK 116 & $\begin{array}{l}\text { Aguchik Island } \\
\text { Tombolo }\end{array}$ & Beta-74673 & 2970 & 60 & $\mathrm{CH}$ & $\begin{array}{l}\text { non-cultural } \\
\text { (RSL estimate } \\
@ 1.8 \mathrm{~m} \text { asl) }\end{array}$ & $\begin{array}{l}\text { Crowell \& Mann } \\
1996\end{array}$ \\
\hline XMK 118 & $\begin{array}{l}\text { Kukak Point } \\
\text { Village }\end{array}$ & Beta-75319 & 900 & 60 & $\mathrm{CH}$ & midden & $\begin{array}{l}\text { Crowell \& Mann } \\
1996\end{array}$ \\
\hline XMK 119 & $\begin{array}{l}\text { Kaflia River } \\
\text { mouth }\end{array}$ & Beta-75320 & 3350 & 90 & $\mathrm{CH}$ & midden & $\begin{array}{l}\text { Crowell \& Mann } \\
1996\end{array}$ \\
\hline XMK 120 & $\begin{array}{l}\text { Kaflia River } \\
\text { mouth }\end{array}$ & Beta-75321 & 460 & 70 & $\mathrm{CH}$ & midden & $\begin{array}{l}\text { Crowell \& Mann } \\
1996\end{array}$ \\
\hline
\end{tabular}




\section{REFERENCES FOR APPENDIX B}

Betts RC, Wooley CB, Mobley CM, Haggarty JC, Crowell A. 1991. Site protection and oil spill treatment at SEL-188: an archaeological site in Kenai Fjords National Park, Alaska. Anchorage: Exxon Shipping Company and Exxon Company.

Clark DW. 1966a. Perspectives in the prehistory of Kodiak Island, Alaska. American Antiquity 31(3):35871.

Clark DW. 1966b. Two late prehistoric pottery-bearing sites on Kodiak Island, Alaska. Arctic Anthropology 3(2):157-84

Clark DW. 1984. Prehistory of the Pacific Eskimo region. In: Damas D, editor. Handbook of North American Indians. Volume 5, Arctic. Washington, DC: Smithsonian Institution. p 136-48.

Clark DW. 1997. The early Kachemak phase on Kodiak Island at Old Kiavik. Archaeological Survey of Canada Paper 155. Hull: Canadian Museum of Civilization.

Clark GH. 1977. Archaeology on the Alaska Peninsula: the coast of Shelikof Strait, 1963-1965. Eugene: University of Oregon Anthropological Papers No. 13

Crowell AL. 2003. The Kenai Fjords oral history and archaeology project preliminary research report [draft teport]. Ocean Alaska Science and Learning Center Grant, 2002.

Crowell AL, Mann DH. 1996. Human populations, sealevel change, and the archaeological record of the northern Gulf of Alaska coastline. Arctic Anthropology 33(2):16-37.

Crozier SN. 1989. Excavation at a late prehistoric dwelling structure on Kodiak Island, Alaska. Arctic Anthropology 26(2):78-95.

Dekin Jr AA, Cassell MS, Ebert JI, Camilli E, Kerley JM, Yarborough MR, Stahl PA, Trucy BL. 1993. Exxon Valdez Oil Spill Archaeological Damage Assessment, final report. The Research Foundation of the State University of New York, Binghamton.

Dotter W. 1988. 1987 BIA ANCSA 14(h)l field investigations in Prince William Sound and adjacent areas. Paper presented at the 13th Annual Meeting of the Alaska Anthropological Association, Fairbanks.

Erlandson J, Crowell A, Wooley C, Haggarty J. 1992. Spatial and temporal patterns in Alutiiq paleodemography. Arctic Anthropology 29(2):42-62.

Fitzhugh B. 2003. The Evolution of Complex HunterGatherers: Archaeological Evidence from the North Pacific. New York: Springer. 332 p.

Haggarty JC, Wooley CB, Erlandson JM, Crowell A. 1991. The 1990 Exxon Cultural Resource Program: site protection and maritime cultural ecology in Prince William Sound and the Gulf of Alaska. Anchorage: Exxon Shipping Company and Exxon Company.

Jordan RH, Knecht RA. 1988. Archaeological research on western Kodiak Island, Alaska: the development of Koniag culture. In: Shaw RD, Harritt RK, Dumond
DE, editors. The Late Prehistoric Development of Alaska's Native People. Anchorage: Alaska Anthropological Association Monograph No. 4. p 225-306.

Kent R, McCallum M. 1991. Report of investigations for Chugach Alaska Corporation, sites BLM AA-10720 through BLM AA-41502. Anchorage: Bureau of Indian Affairs, Alaska Native Claims Settlement Act (ANCSA) Office.

Mills RO. 1994. Radiocarbon calibration of archaeological dates from the central Gulf of Alaska. Arctic Anthropology 31:126-49.

Partlow M. 2000. Salmon intensification and changing household organization in the Kodiak Archipelago [unpublished $\mathrm{PhD}$ dissertation]. Madison: University of Wisconsin.

Reger DR. 1987. Archaeology of a late prehistoric subsistence locality, the Clam Gulch site (49KEN-O45). Anthropological Papers of the University of Alaska 21 (1/2):89-103.

Reger DR, Boraas A. 1996. An overview of the radiocarbon chronology in Cook Inlet prehistory. In: Davis NY, Davis WE, editors. Adventures Through Time: Readings in the Anthropology of Cook Inlet, Alaska. Anchorage: Cook Inlet Historical Society. p 155-71.

Reger DR, McMahan JD, Holmes CE. 1992. Effect of crude oil contamination on some archaeological sites in the Gulf of Alaska, 1991 investigations. Office of History and Archaeology Report No. 30, Division of Parks and Natural Resources, Alaska Department of Natural Resources.

Saltonstall PG, Carver GA. 2002. Earthquakes, subsidence and prehistoric site attrition: a view from the Settlement Point site, Kodiak Archipelago, Alaska. In: Torrence R, Grattan J, editors. Natural Disasters, Catastrophism, and Cultural Change. New York: Routledge. p 172-92.

Schaaf T, Johnson L. 1990. Upland investigations at SEL-188, Kenai Fjords National Park. Anchorage: National Park Service.

Steffian AF. 1992. Fifty years after Hrdlicka: further investigations at the Uyak site, Kodiak Island, Alaska. Anthropological Papers of the University of Alaska 24(1/2):141-64.

Workman WB, Workman KW. 1997. 1996 test excavations at a late prehistoric site at Port Graham, Kenai Peninsula, Alaska. Paper presented at the 25th Annual Meeting of the Alaska Anthropological Association, April 1997.

Yarborough LF. 1997. Exxon Valdez Oil Spill Restoration, final report. Site-specific archaeological restoration at SEW-440 and SEW-488; Restoration project 95007B. USDA Department of Agriculture, Chugach National Forest, Alaska. 228 p.

Yarborough MR, Yarborough LF. 1991. Uqciuvit: a multicomponent site in northwestern Prince William Sound, Alaska. Anchorage: USDA Forest Service. 


\section{APPENDIX C}

Locations of Dated Prehistoric Archaeological Sites in the Prince William Sound (PWS), Kenai (KEN), and Kodiak-Katmai (KOKA) Tectonic Segments, Southern Alaska

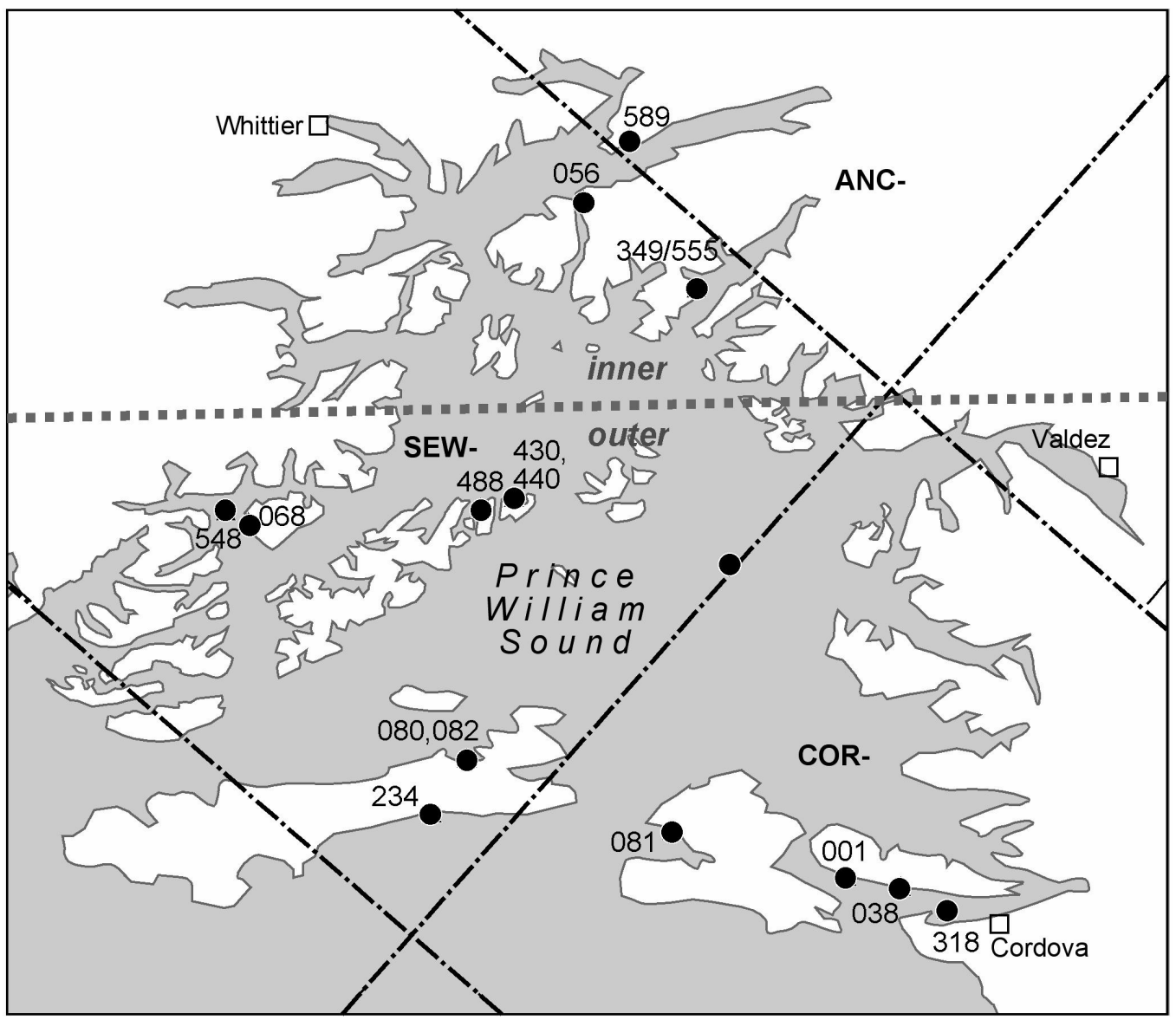

Dated prehistoric coastal archaeological sites in the PWS segment 


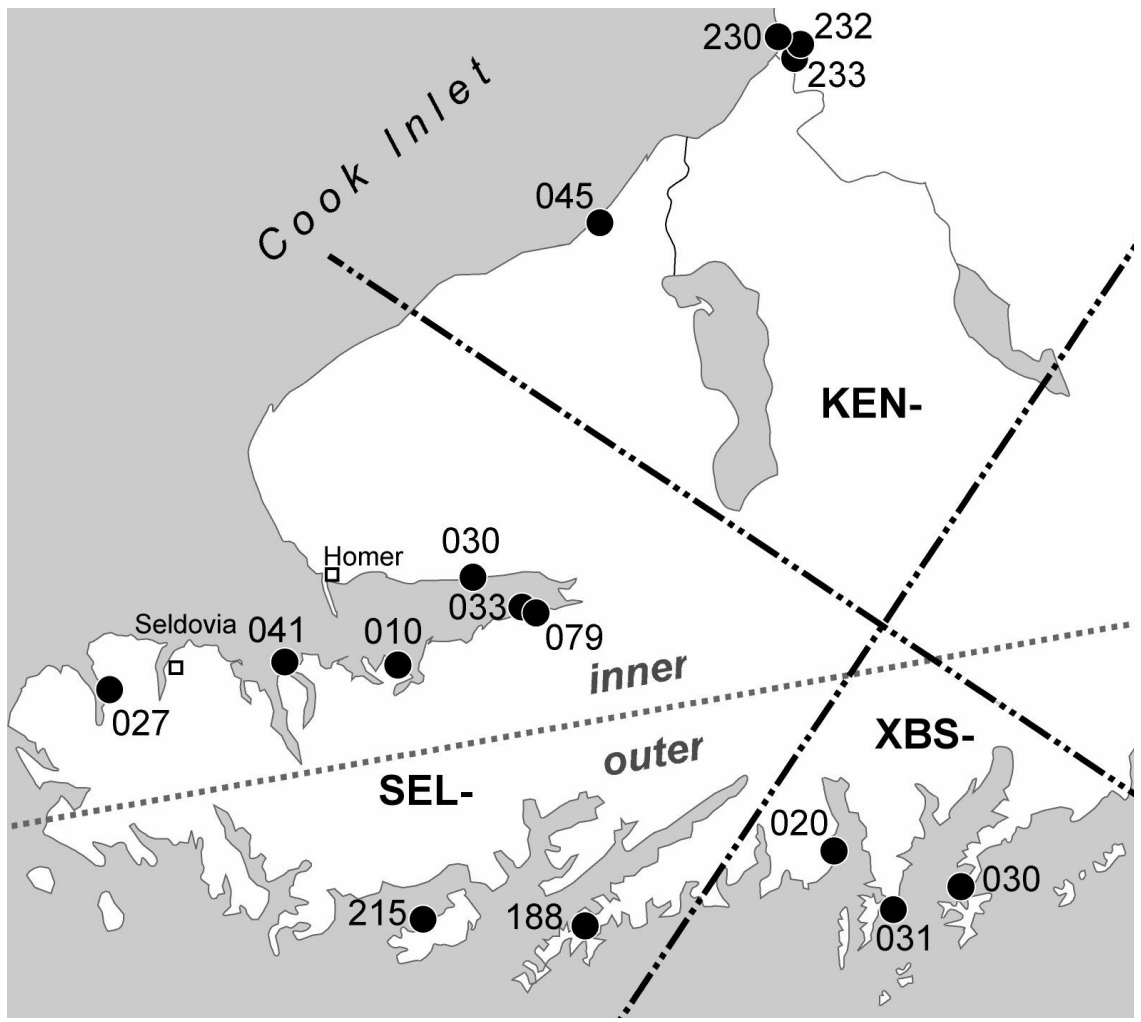

Dated prehistoric coastal archaeological sites in the KEN segment

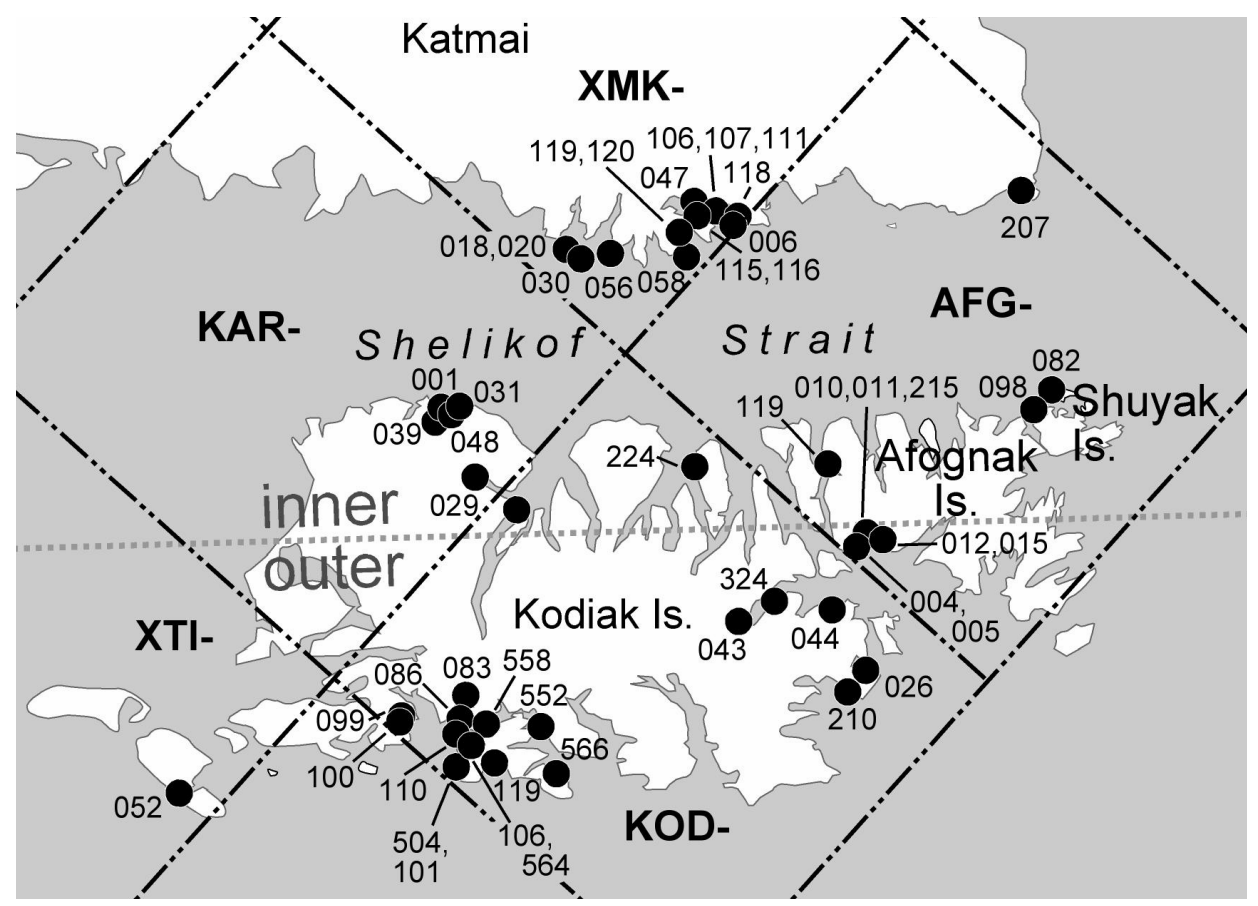

Dated prehistoric coastal archaeological sites in the KOKA segment 


\section{APPENDIX D}

\section{Coastal Prehistoric Archaeological Sites, Southern Alaska: ${ }^{14} \mathrm{C}$ Age Distributions}

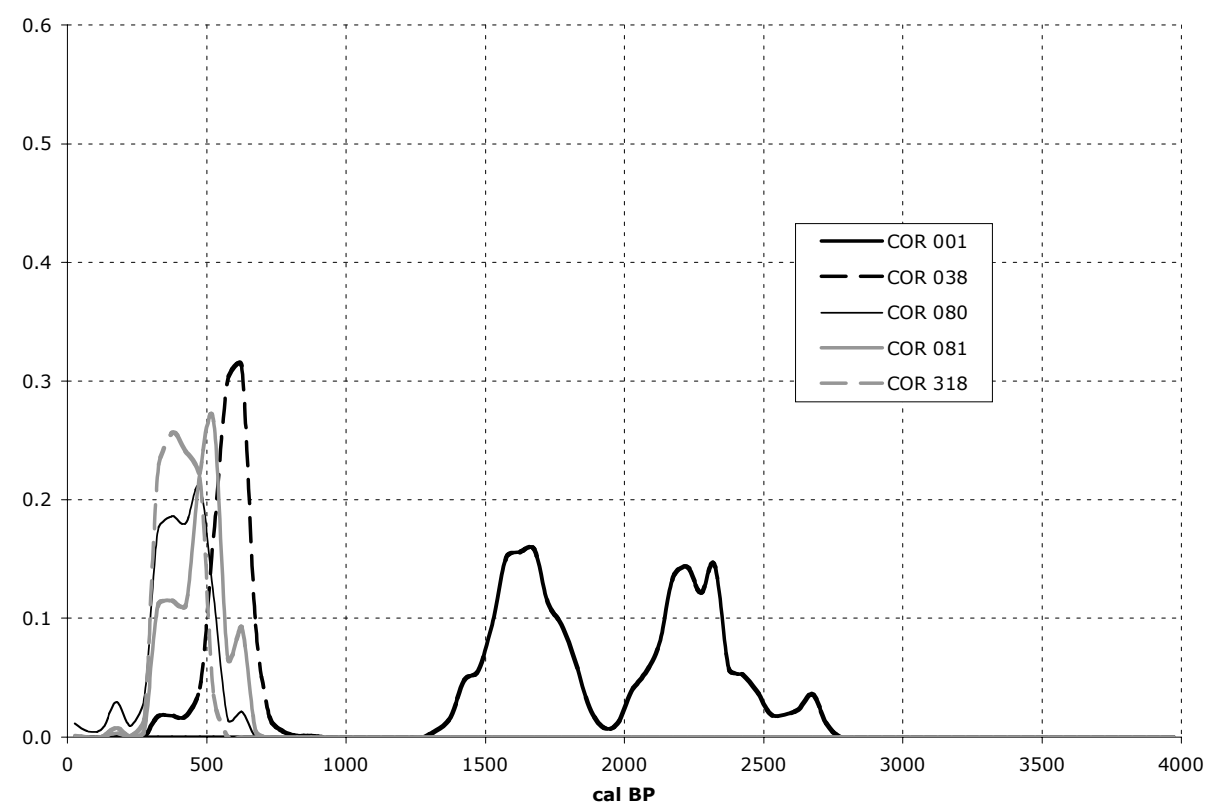

Probability density function (PDF) of calibrated ${ }^{14} \mathrm{C}$ ages from prehistoric villages and camps on the outer coast of the Prince William Sound segment (I).

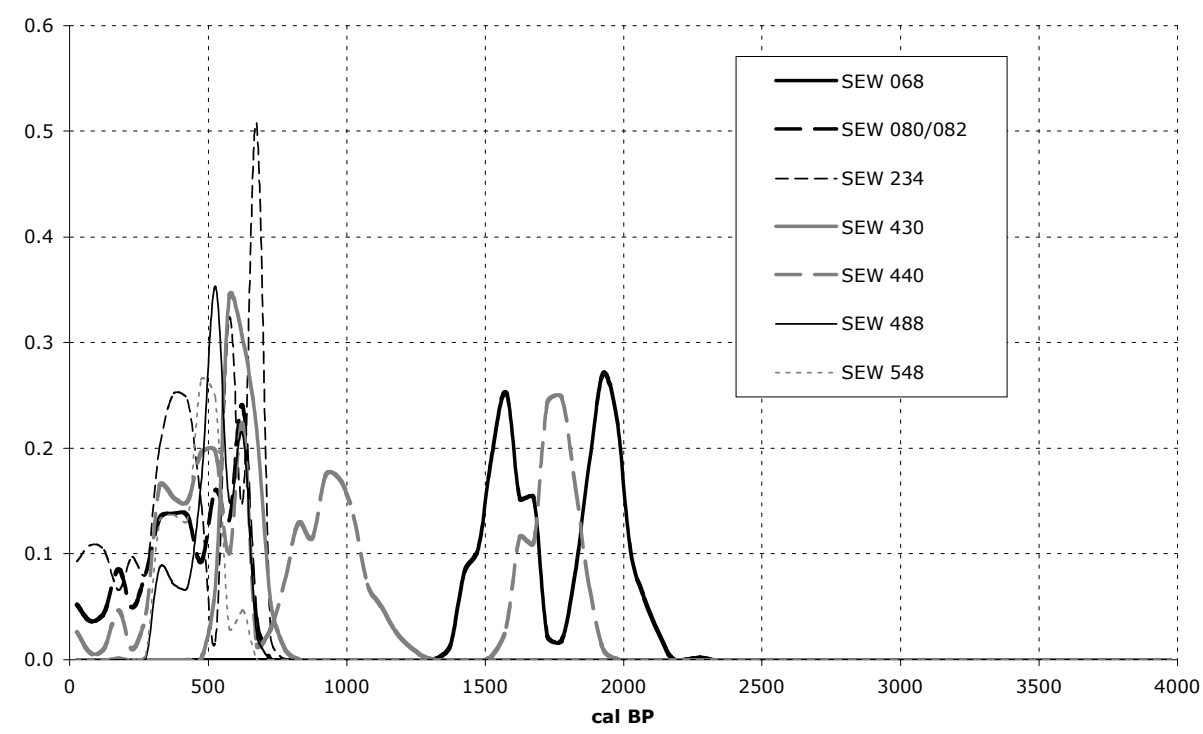

PDF of calibrated ${ }^{14} \mathrm{C}$ ages from prehistoric villages and camps on the outer coast of the Prince William Sound segment (II). 


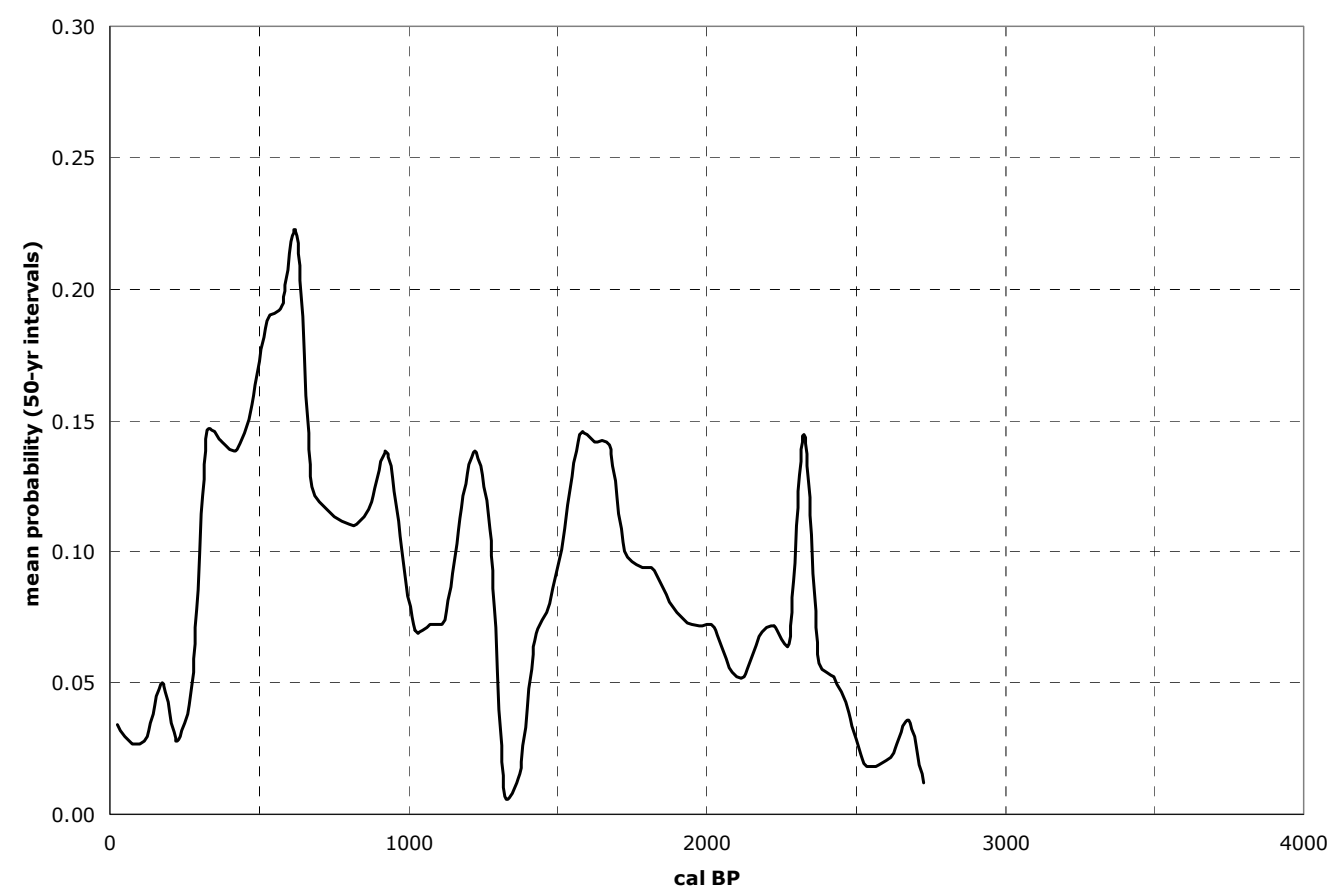

Composite PDF of calibrated ${ }^{14} \mathrm{C}$ ages from the outer coast of the Prince William Sound segment

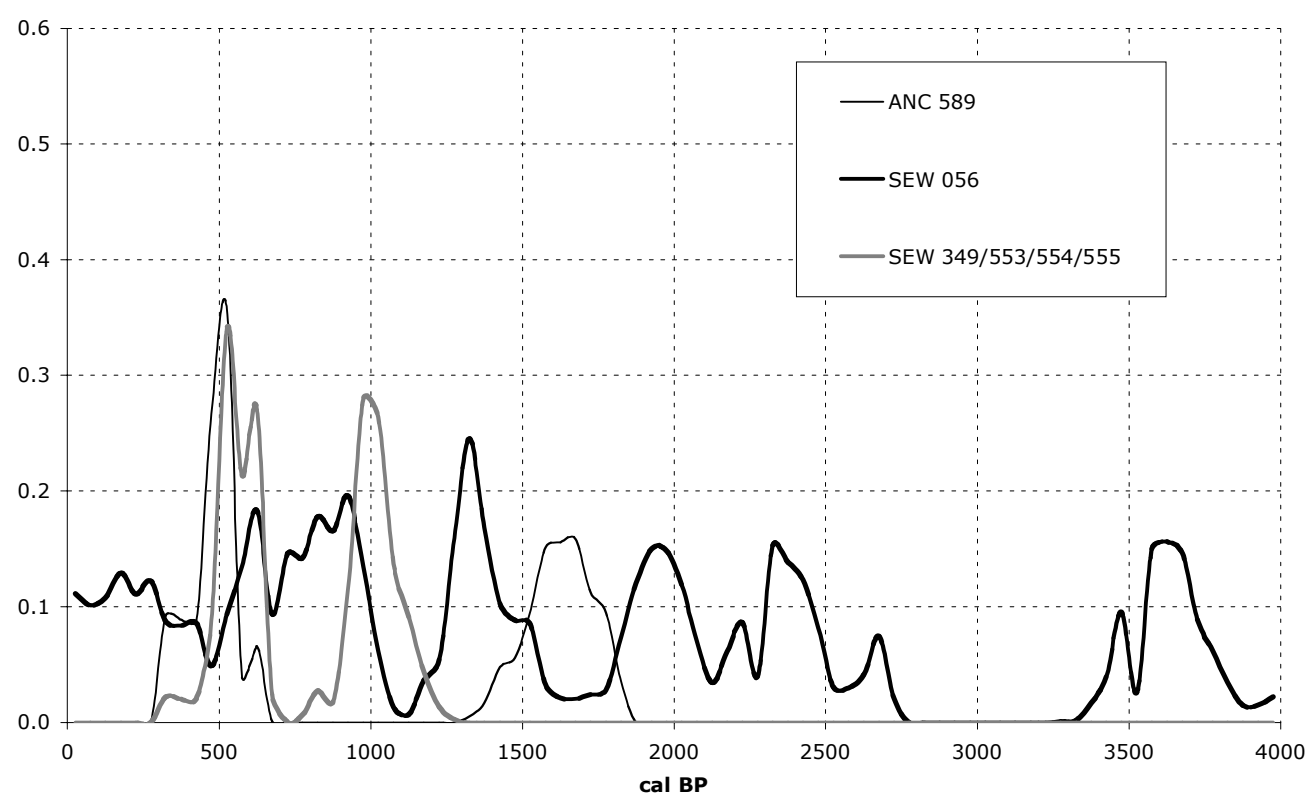

PDFs of calibrated ${ }^{14} \mathrm{C}$ ages from prehistoric villages and camps on the inner coast of the Prince William Sound segment 


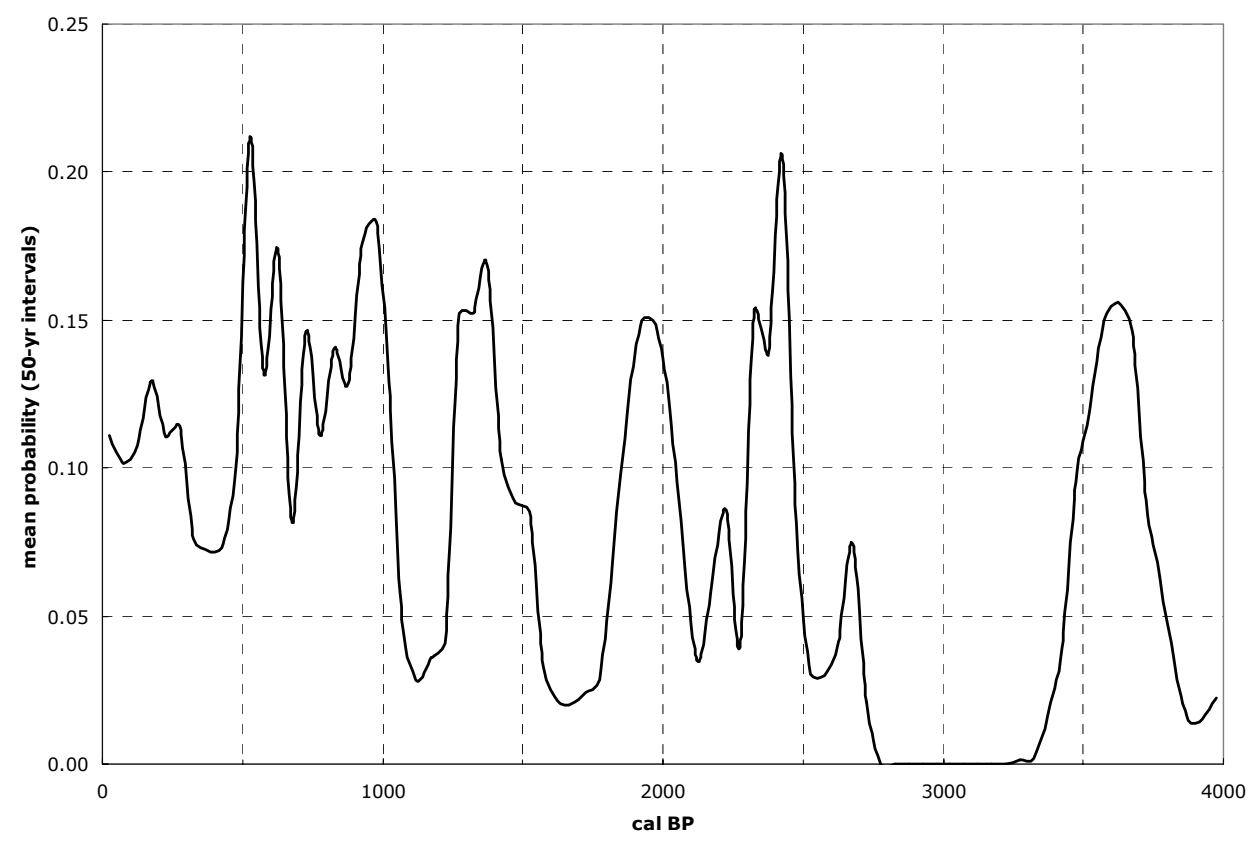

Composite PDF of calibrated ${ }^{14} \mathrm{C}$ ages from the inner coast of the Prince William Sound segment

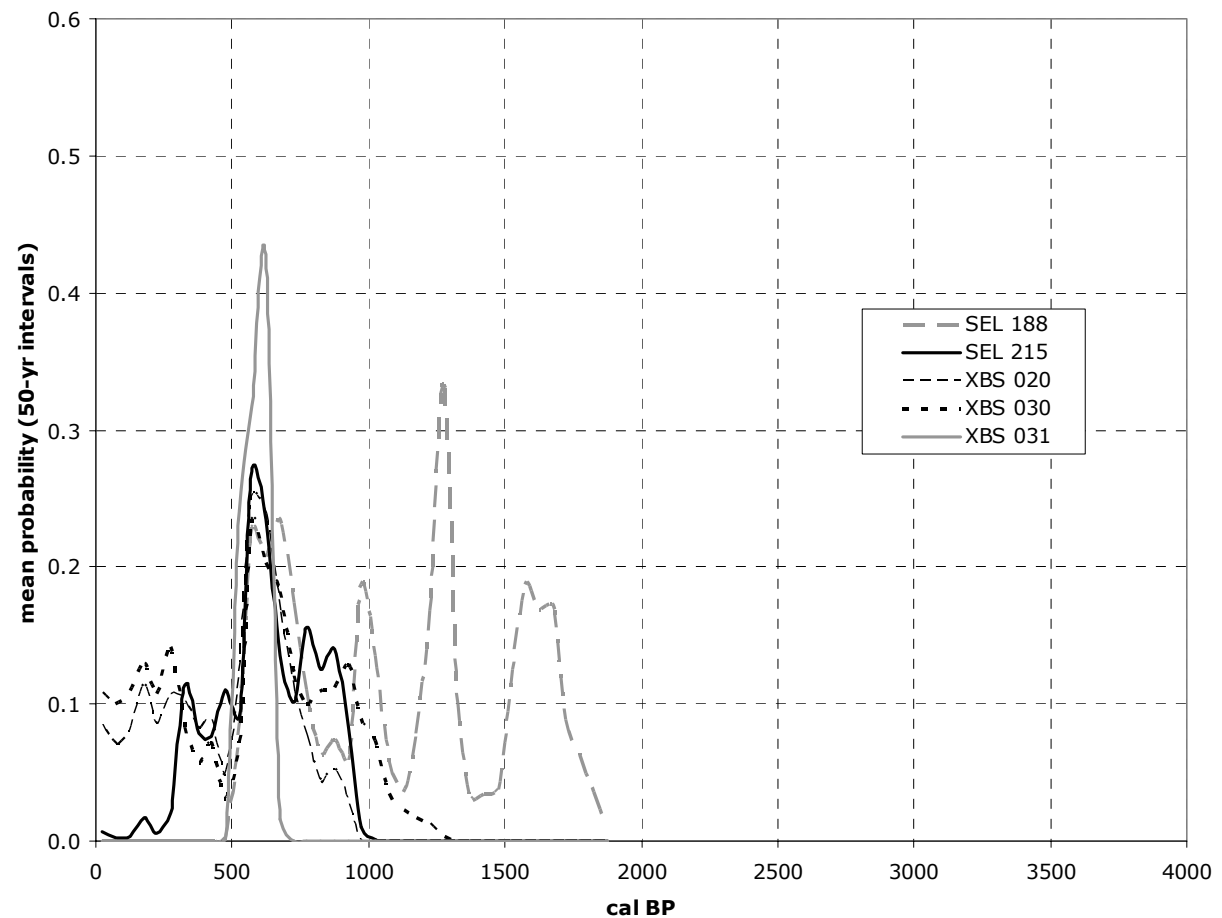

PDFs of calibrated ${ }^{14} \mathrm{C}$ ages from prehistoric villages and camps on the outer coast of the Kenai segment 


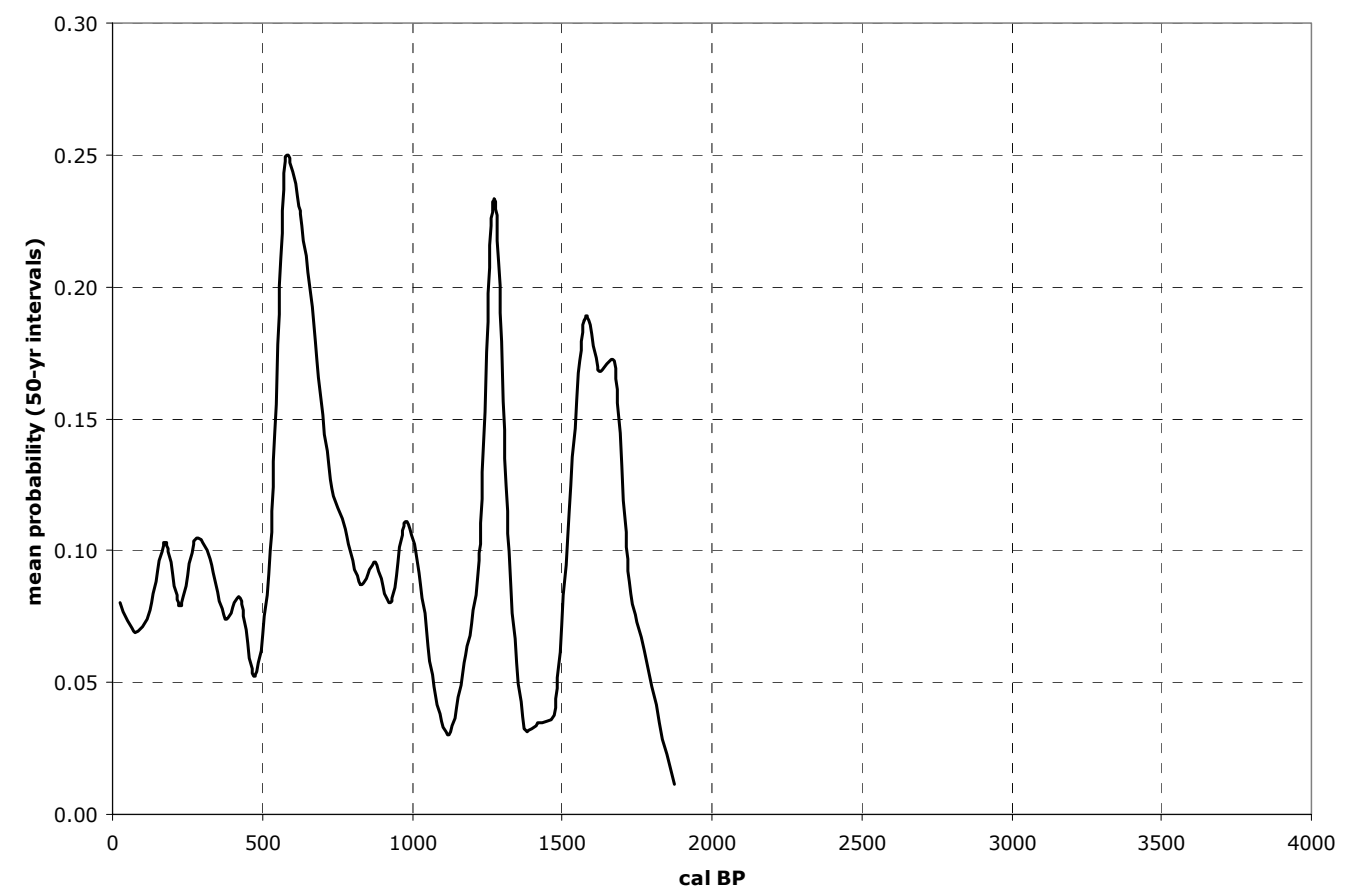

Composite PDF of calibrated ${ }^{14} \mathrm{C}$ ages from the outer coast of the Kenai segment

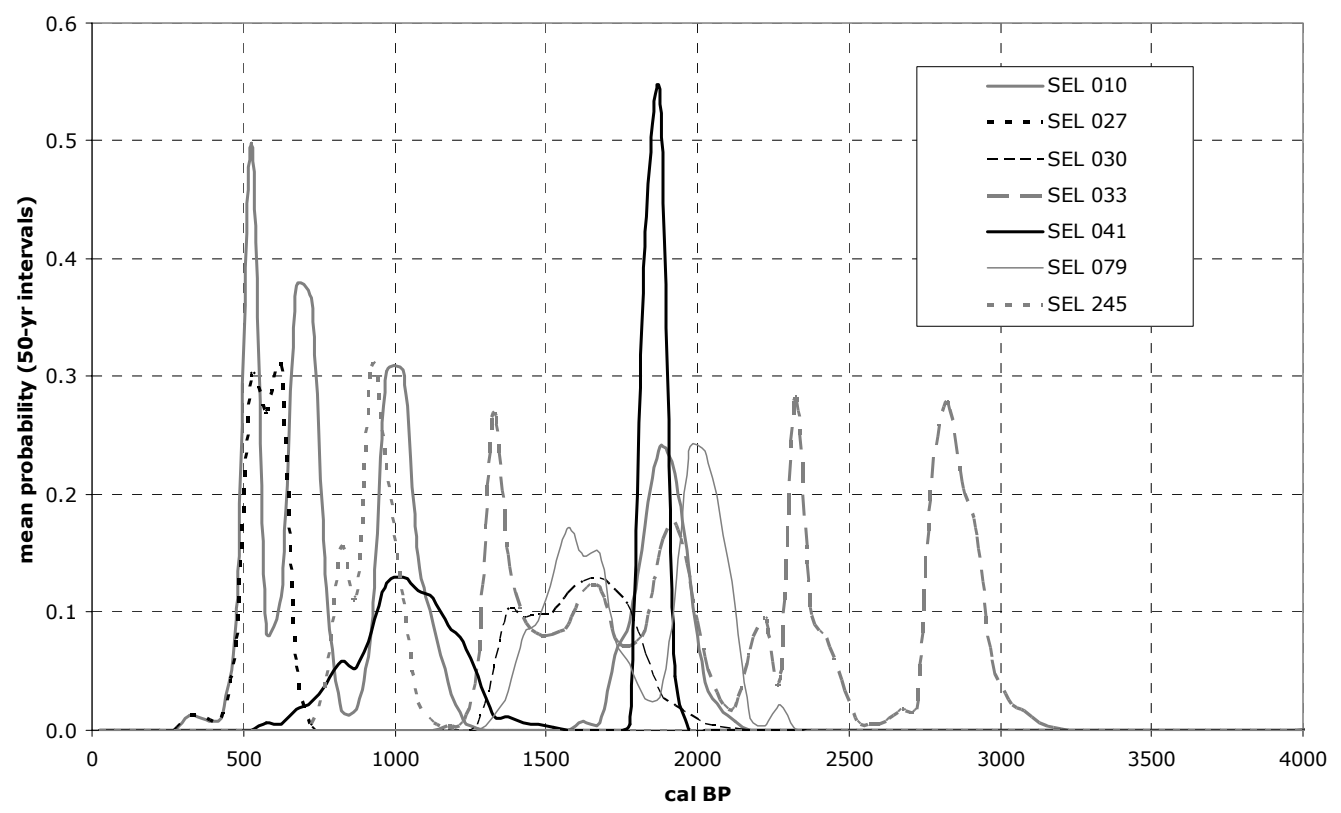

PDFs of calibrated ${ }^{14} \mathrm{C}$ ages from prehistoric villages and camps on the inner coast of the Kenai segment 


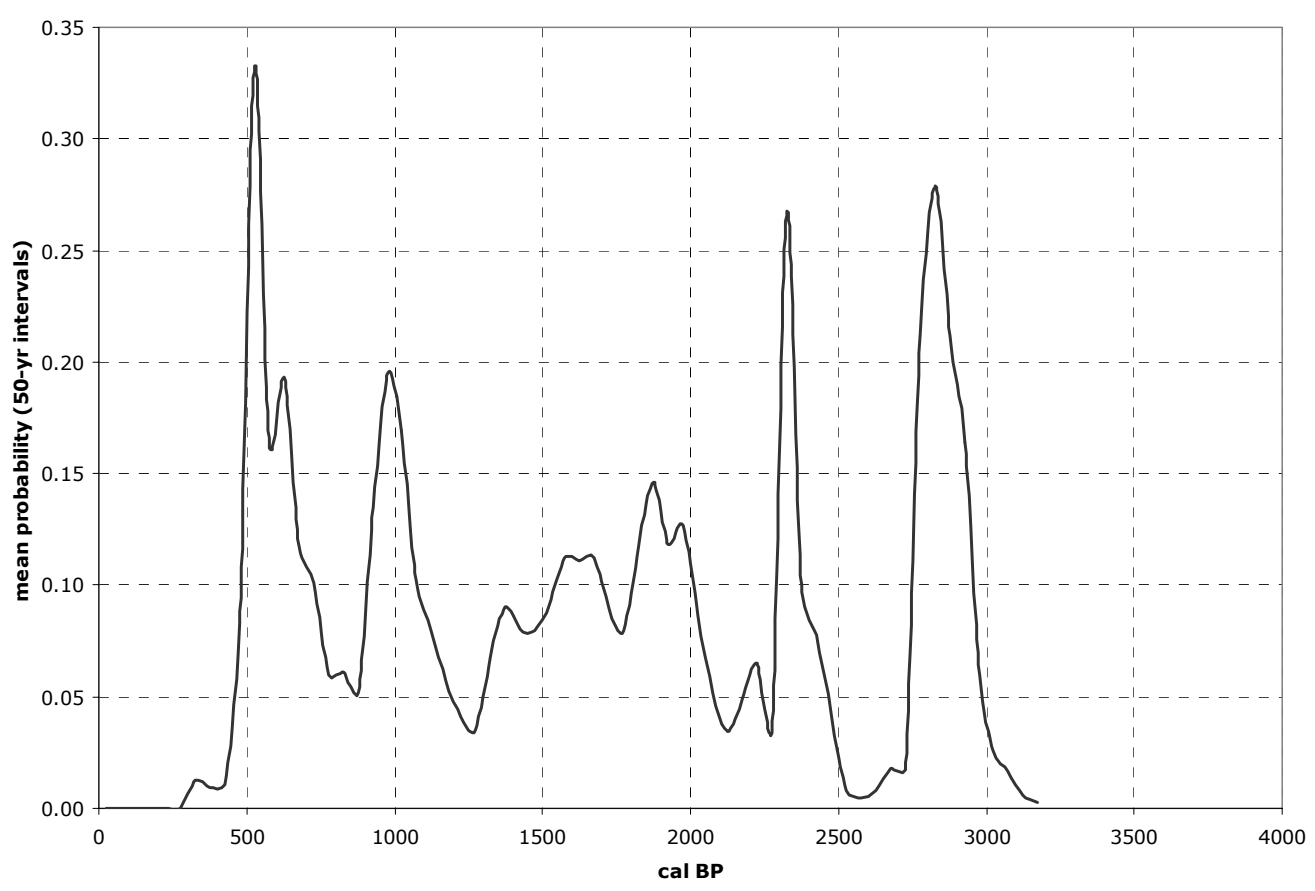

Composite PDF of calibrated ${ }^{14} \mathrm{C}$ ages from the inner coast of the Kenai segment

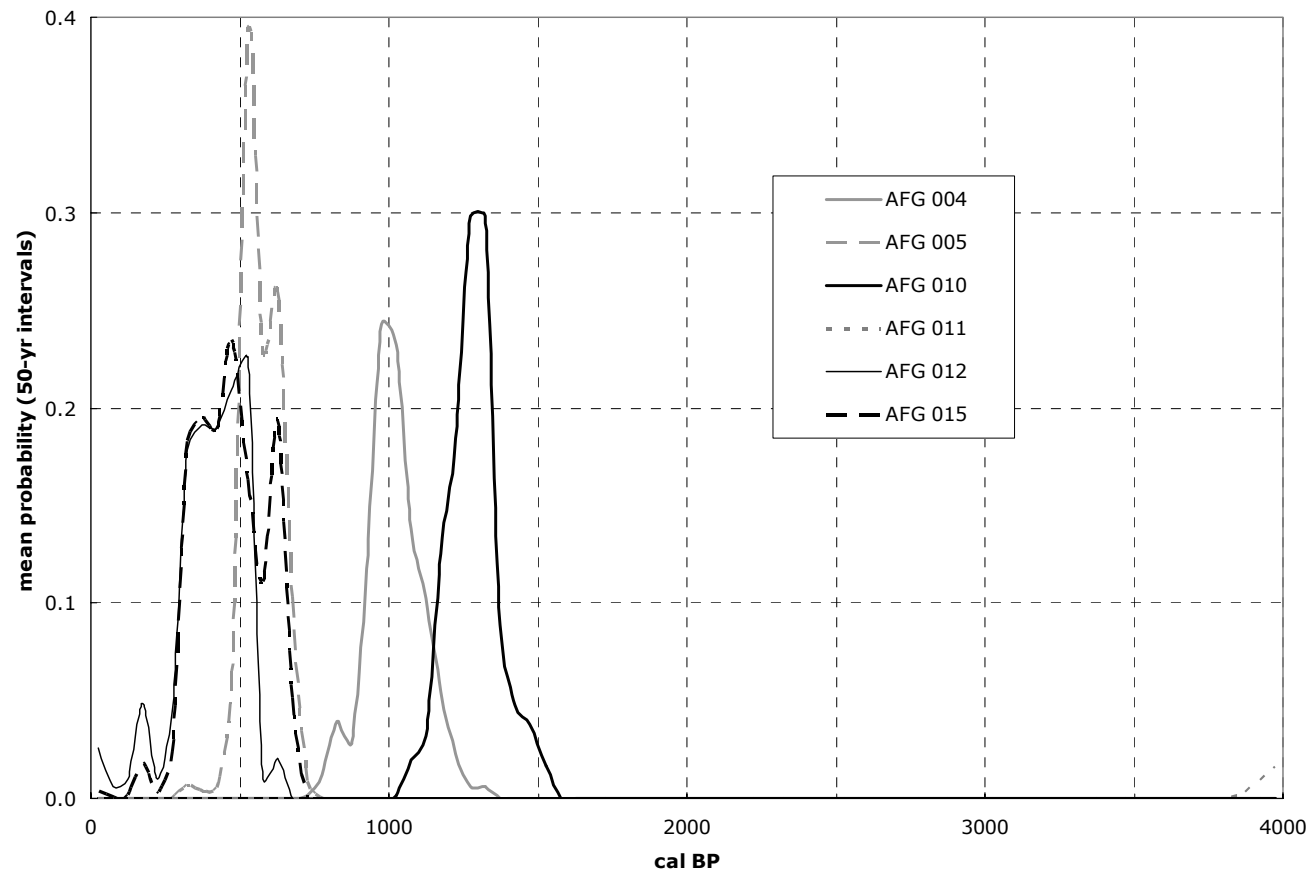

PDFs of calibrated ${ }^{14} \mathrm{C}$ ages from prehistoric villages and camps on the outer coast of the Kodiak-Katmai segment (I) 


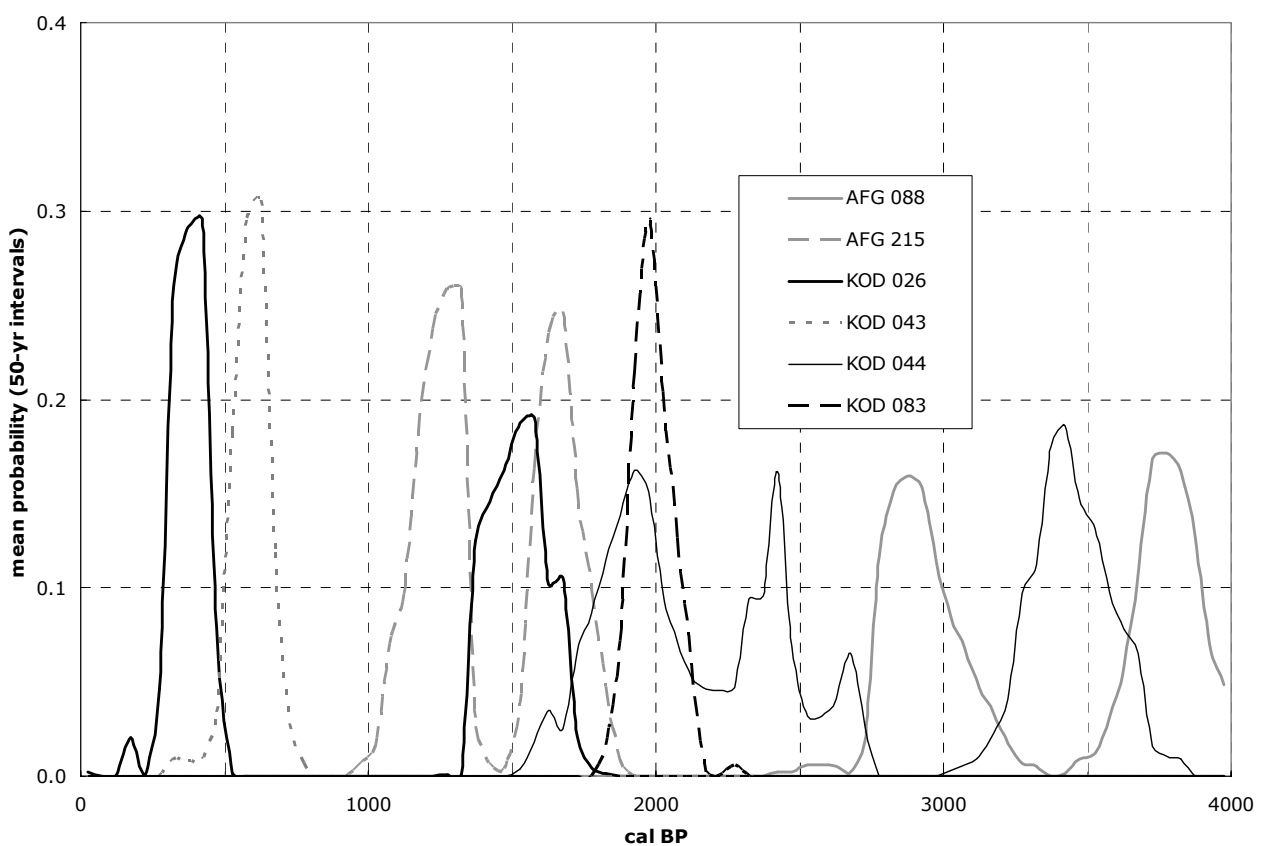

PDFs of calibrated ${ }^{14} \mathrm{C}$ ages from prehistoric villages and camps on the outer coast of the Kodiak-Katmai segment (II)

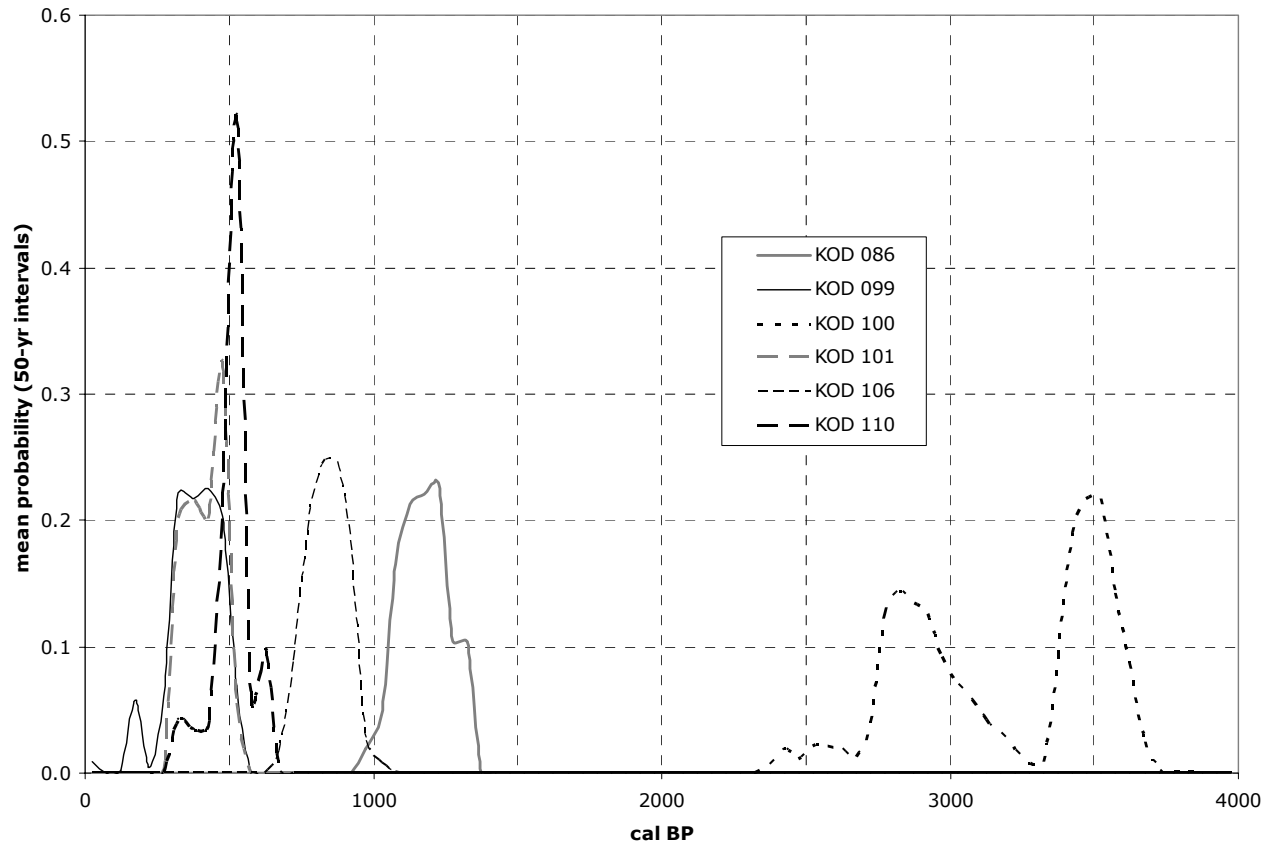

PDFs of calibrated ${ }^{14} \mathrm{C}$ ages from prehistoric villages and camps on the outer coast of the Kodiak-Katmai segment (III) 


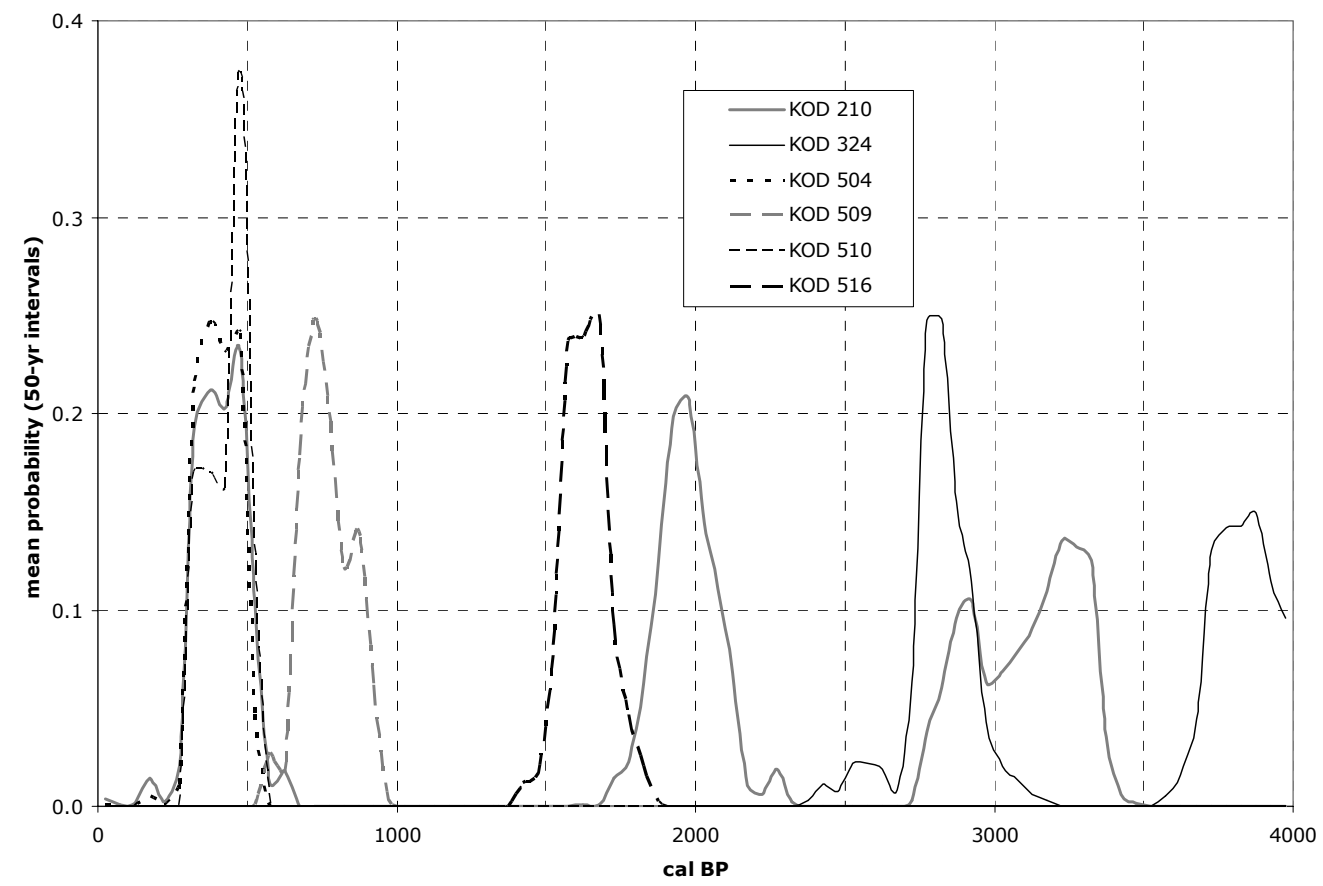

PDFs of calibrated ${ }^{14} \mathrm{C}$ ages from prehistoric villages and camps on the outer coast of the Kodiak-Katmai segment (IV)

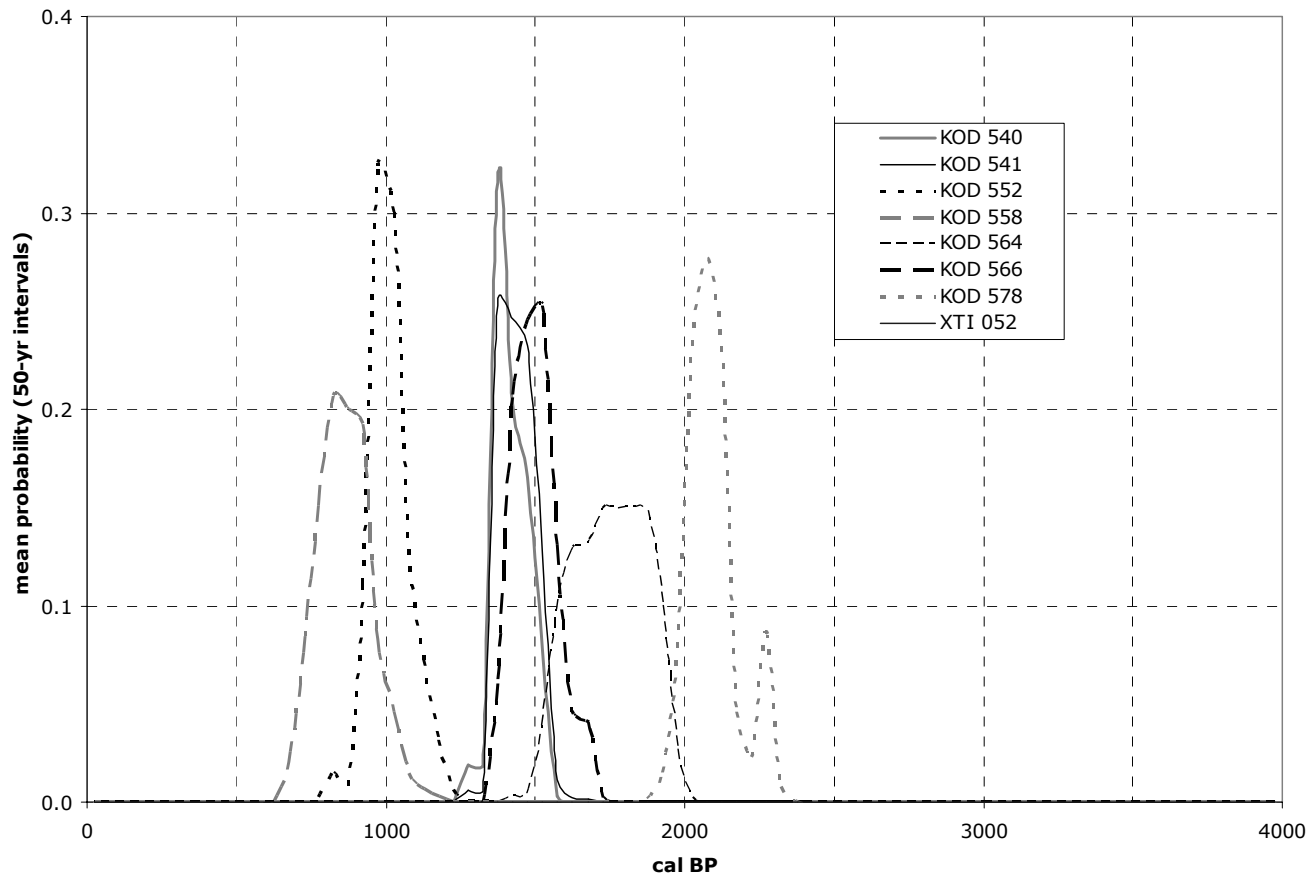

PDFs of calibrated ${ }^{14} \mathrm{C}$ ages from prehistoric villages and camps on the outer coast of the Kodiak-Katmai segment (V) 


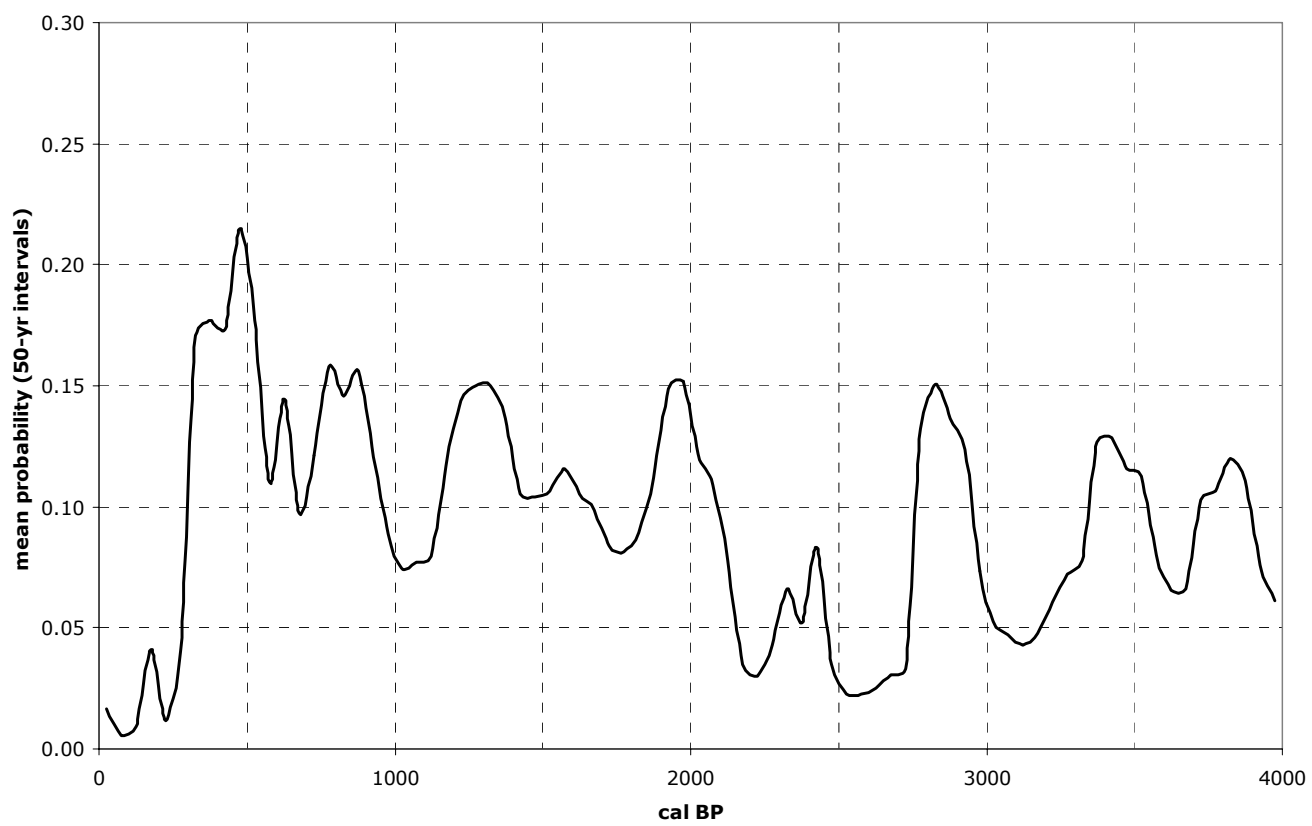

Composite PDF of calibrated ${ }^{14} \mathrm{C}$ ages from the outer coast of the Kodiak-Katmai segment



PDFs of calibrated ${ }^{14} \mathrm{C}$ ages from prehistoric villages and camps on the inner coast of the Kodiak-Katmai segment (I) 


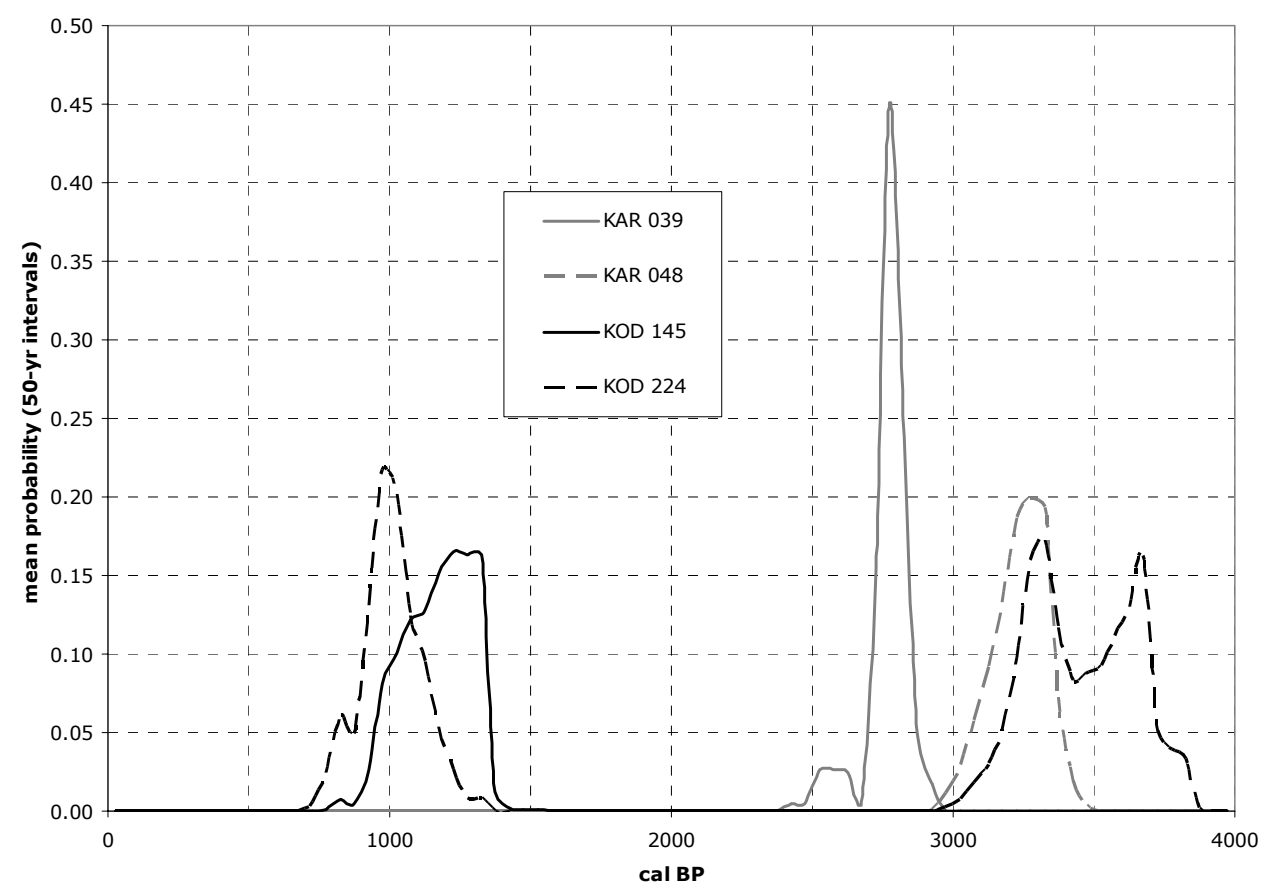

PDFs of calibrated ${ }^{14} \mathrm{C}$ ages from prehistoric villages and camps on the inner coast of the Kodiak-Katmai segment (II)

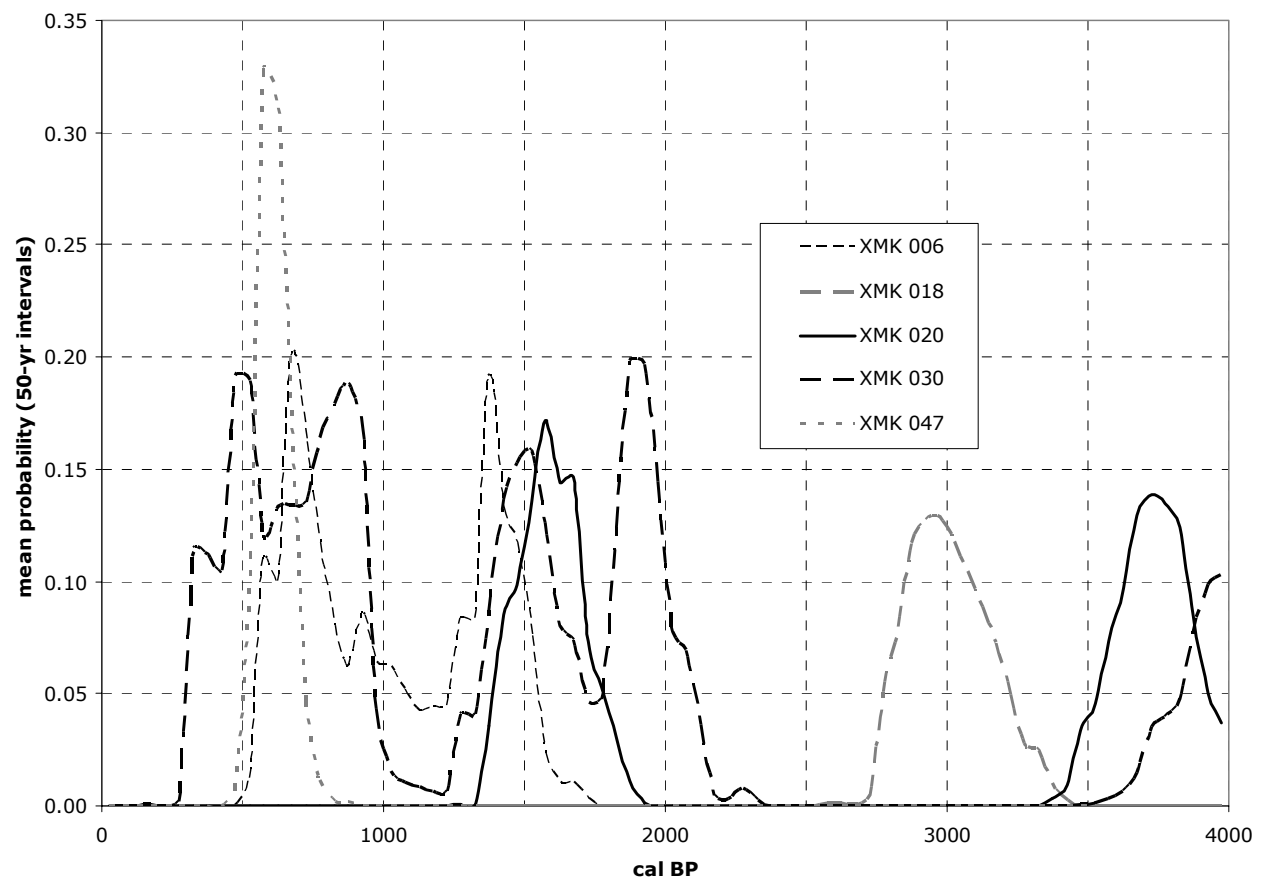

PDFs of calibrated ${ }^{14} \mathrm{C}$ ages from prehistoric villages and camps on the inner coast of the Kodiak-Katmai segment (III) 


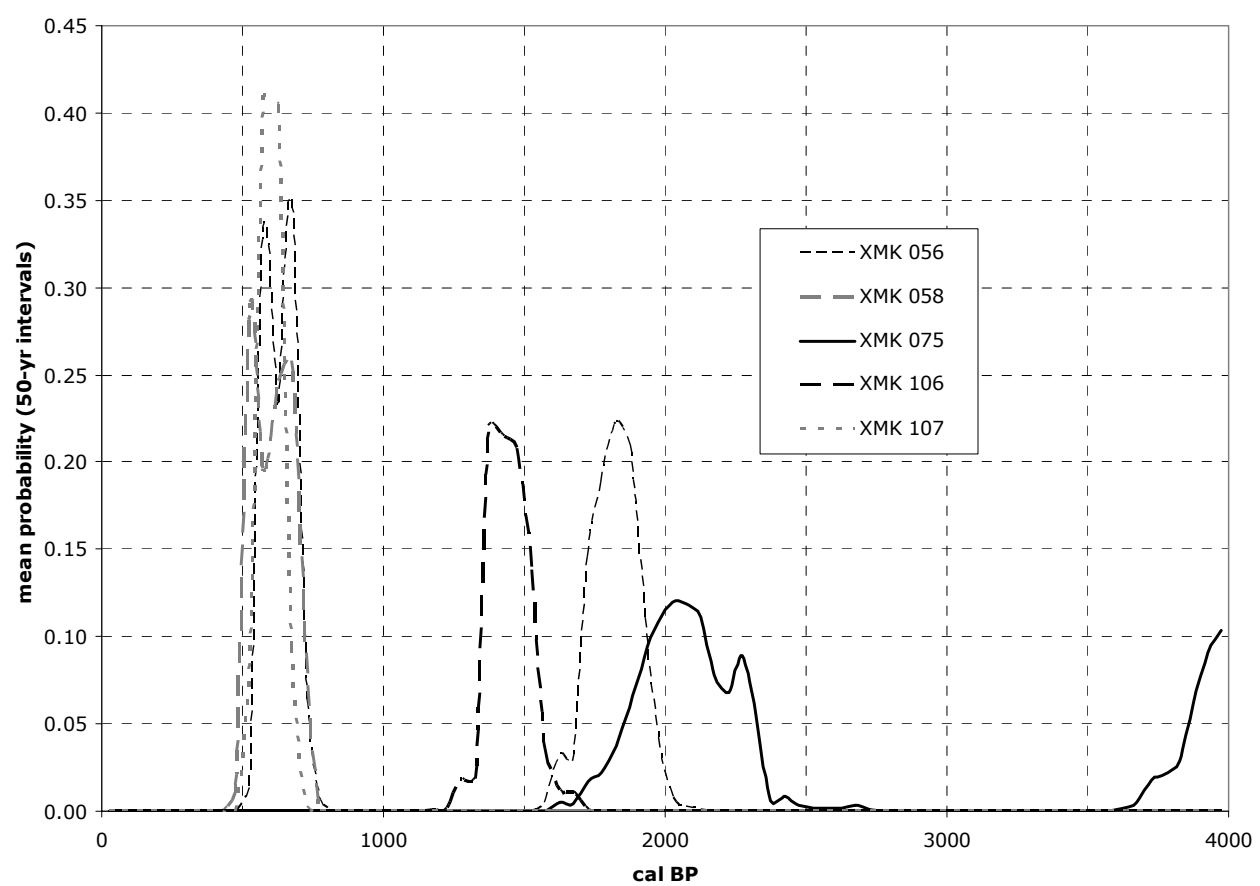

PDFs of calibrated ${ }^{14} \mathrm{C}$ ages from prehistoric villages and camps on the inner coast of the Kodiak-Katmai segment (IV)

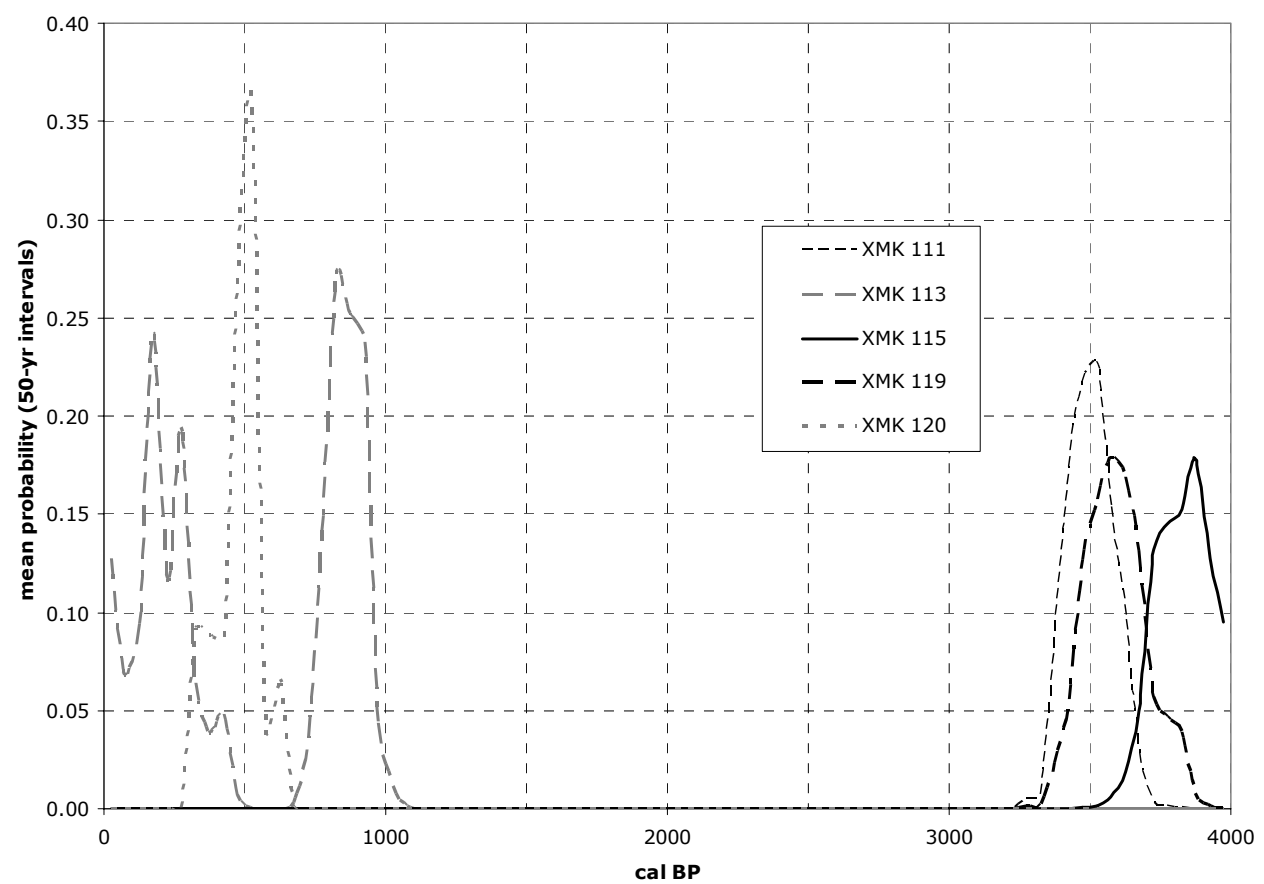

PDFs of calibrated ${ }^{14} \mathrm{C}$ ages from prehistoric villages and camps on the inner coast of the Kodiak-Katmai segment (V) 


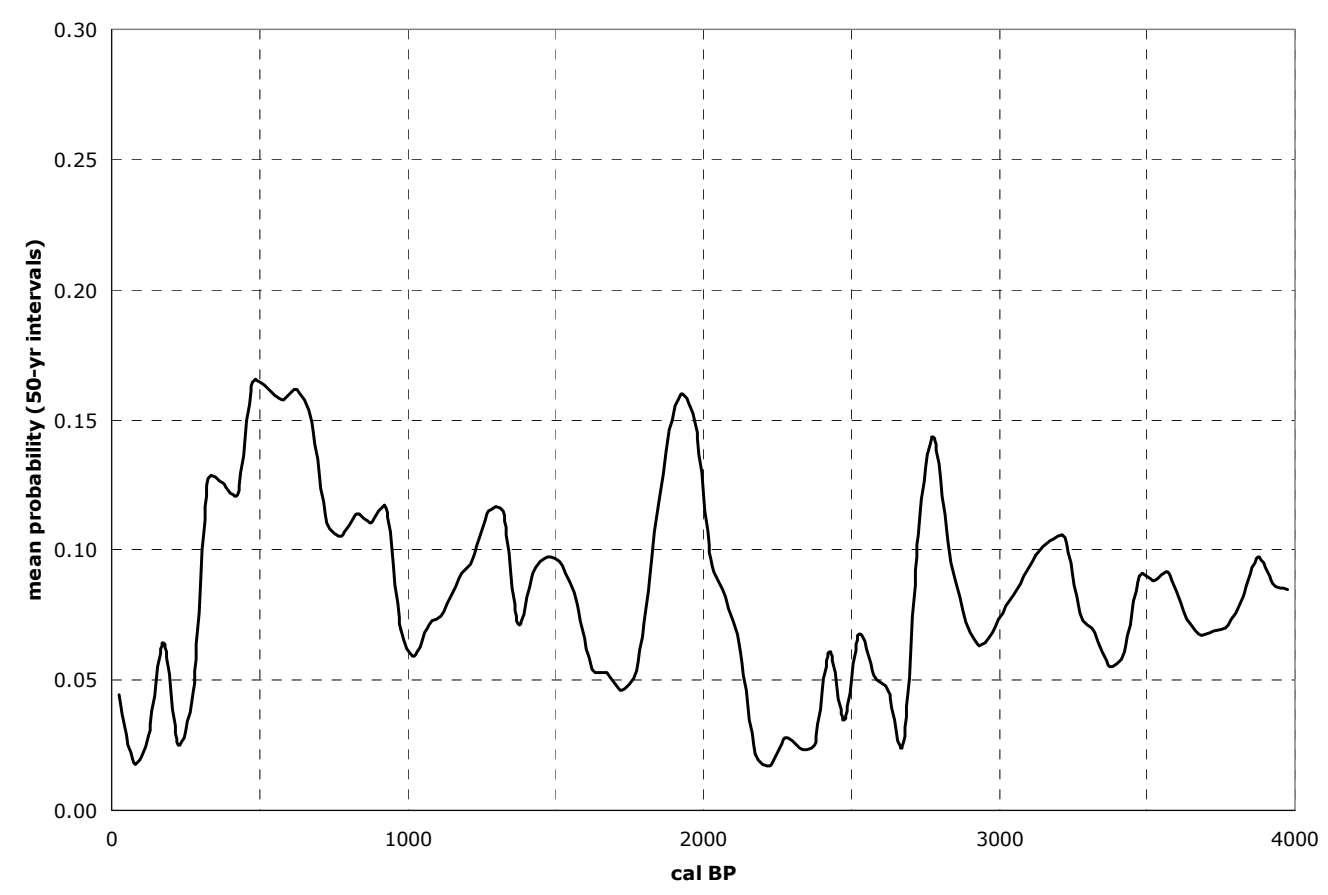

Composite PDF of calibrated ${ }^{14} \mathrm{C}$ ages from the inner coast of the Kodiak-Katmai segment 